一般演題抄録 
10-F-14:00

\section{婦人科疾患における瘀血に対する 鍼炎}

関西鍼众短期大学東洋医学基礎教室 戸田静男

【目的】婦人科疾患と瘀血の関係は、古来より 「血の道症」ということばがあるくらい密接な関 係がある。特に、疾血の腹証は小復急結が特徵的 である。このようなことは、『金實要略』をはじ めとする歴代の医書にも多く記載されている。そ して、それに対する鍼众についても数多く論じら れている。今回は、中国および日本の歴代の医学 文献より婦人科疾患における瘀血に対する銊众に ついて考察したので報告する。

【方法】中国および日本の漢方医書（たとえば、 『金匱要略』、『萬安方』、『諸病源候論』、『有林福 田方』など）、腹診書（たとえば、『腹証奇覧』、 『腹診録』、『東洞先生腹診伝』、『腹候要訣』など)、 鍼尒医書（たとえば、『鍼尒要穴』、『鍼尒秘書』、 『鍼書』、『鍼众五藴抄』など）などを参照して、 考察がなされた。

【結果】更年期障害、月経不順をはじめとした婦 人科疾患では、瘀血が生じ、小腹急結、小腹鞕満 とよばれる状態となる。婦人科疾患は、任脈と衝 脈とに特に密接な関係があつた。これら二脈の気 血が衰えると、月経不順が起こると考えられてい た。鍼众治療では、気海、天枢などの経穴がよく 使われていた。

【考察】以上のように、婦人科疾患と瘀血には密 接な関係があった。そして、それらに対する銊尒 治療が試みられたといってよい。

【結語】婦人科疾患における疼血およびその腹証 である小腹急結の存在は非常に重要といえる。そ して、その鍼多治療はそれを目標として行われた といってもよい。

キーワード : 婦人科疾患、瘀血、小腹急結
10-F-14:12

東洋医学の学理研究（第3報）

一東洋医学の原点を易の論理にもとめて一

清野鍼尒整骨院・東京地方会

清野充典

【緒言】はじめに、昨今の東洋医学領域特に鍼、 众に関する学問体系及び研究は、東洋思想（中国 思想）に基づいていないうえに、その東洋医学 （鍼众医術）の原理論と臨床実践が乘離している 点がさらに東洋医学の発展を妨げていると考える。 演者は東洋医学の理論と実践が一致した共通の言 語が必要と考えており、それを漢字文化の原点と なっている「易」の論理を元に検討を行っている。

【方法】易は今日、王強の注釈本を元にした「十 三経注疏」が底本と考えられている。易が太極か ら八卦（乾・兌・離・震・巽・坎・艮・坤）に派 生するまでの思想とその文字を検討し、その背景 にある身体の見方・病態把握について検討してみ た。

【結果】『易經』の繋辞傳に「易に太極あり、こ れ両儀を生ず。両儀四象を生じ、四象八卦を生ず。」 とある。医学に置き換えると、『太極』はヒト、 『両儀』は身体を陰陽で見ようという思想、と理 解できる。『両儀四象を生じ』とは、老陰、老陽、 少陰、少陽のことである。易では「虚」は「陰」、 「実」は「陽」という意味で用いられている。「四 象」は陰虚・陽実・陰実・陽虚といえる。そして 『四象八卦を生ず』とあるように、「八卦」乾・兌・ 離・震・巽・坎・艮・坤という思想が生まれ、こ れらを元に身体の見方が確立されたと考えられる。 これらは、「五行の色体表」の成立の基本思想と なっている。

【考察と結語】易に基づいた身体の見方・病態把 握の思想を健康体から病体に移行し死を迎えるま でに置き換えると、陰虚・陽実・陰実・陽虚とい う「象」を移行すると考えられる。この思想をも とに、現代医学に基づく病名診断を東洋思想に置 き換えることに応用することや、銊尒の手技を共 通の思想のもとに統一することが鍼尒医学・医療 の発展の鍵を握ると考える。

キーワード：易、太極、両儀、四象、八卦 
10-F-14:24

人中診法に関する中医文献の考察

日本中医推拿研究会

\section{0-F-14:36 生気の制御}

- The control of X-energy (=QI) -
【目的】人中部、別名水溝、鼻下。『霊枢 - 五色』 には「面王以下者、膀胱子処也」「唇厚人中長以 候小腸」という記載がある。中医望診において、 人中部の形態・色沢などを観察して体内の疾病を 推察・診断する方法を人中診法という。中国では 人中診法に関する研究発表は散在でありながら、 注目すべき成果が挙げられる。一方、日本鍼众界 では人中穴を用いて臨床治療に応用するのは大多 数であるが、望診の1部位とされる研究報告は稀 のようである。本研究は、中医学文献データベー スを利用して、人中診法に関する文献を検索し、 その結果をまとめ、私見を加えて報告する。

【方法】「中国中医薬文献数据庫」を on line し て、人中診法というキーワードを用い、この 20 年間発表された文献を検索し、検索された文献を 検討し、文献の信頼性評価を加え、システマティッ ク・レビューを行った。

【結果と考察】人中の色沢・長さ・深浅・しわと 隆起の有無を望診する。この中、人中の長さは診 察指標として多く応用されている。人中短浅もの には不妊症・インポテンスなど、人中狭長ものに は包茎・生理不順などが多く見られる。診察に応 用される範囲は泌尿生殖系疾患のみならず、小腸 や心臓の部分の疾患にも及ぼす。また、形態学に おいて、性成熟期女性の子宮と人中との高い相関 性を有する結論が付けられた調査研究は報告され、 人体組織発生学上において人中と子宮との関連性 が論議された。

【結語】古来の人中診法は今日の臨床診断に有効 に応用され、なおさら銊尒臨床では、人中穴の多 岐的な臨床応用にも可能性が示唆された。ただし、 evidence-based 診察法だとすれば、さらなる測 定手段の客観化・より大規模の症例収集と画像診 断の照合に関する研究は重要であると考えられた。
江南堂鍼众院・山梨地方会

花輪貞良
【目的】古典における補瀉について多く伝えられ、 あるいは解説されているが、検証しても納得出来 なかったので、30年の総括を報告する。

【方法】先ず経穴は、示指腹を該当部位に載せ、 術者の肩から手指迄の力を抜き、腕を軽く引きず ると、その指腹内に、表皮のざらつきとして触知 出来る点をもって確定した。次に刺す深さは、表 皮内に出現するざらつきが目標だから、深さはそ の分、 $0.1 \mathrm{~mm}$ 以内である。そして決め手は鍼尖 をその深さに刺す為に、押し手を固くして簡単に 刺さらないようにして、なお静かに竜頭を摘まん で押す事によって得られる「ひびき=echo」を目 標にすると良い。

【結果】補法の場合、押し手の左右から鍼尖を締 める力を強め、鍼を抜く時の瞬間に、押し手（ま たは刺し手でも可）を横に寝かせ（例えば母指）、 その鍼口＝経穴の部位を閉じる事によって生気の 充実がもたらされ、瀉法の場合は押し手を寝かせ る事なく、鍼口＝経穴を閉じない事によって得ら れる。これらは脉診で確認出来る。

【考察】生気の制御、即ち補瀉の違いが上記の (結果) のように制御出来る事は、そこに何らか の「力」が作用している事を示唆している。演者 は1996年開催の第4回世界鍼尒学会でこの点に触 れ、その強い左右圧の関与から、鍼口から出る何 かの「気体」が関与している可能性がある旨、報 告したが、未だ解明出来ていない。

【結語】手方手技の上から、そして一連の経緯か ら生体における気、即ち生気の制御が補瀉として 作用している事が伺われるが、その本態は未だ解 明出来ない。しかし実地臨床を通して、生気の制 御、即ち補瀉を言葉の上ではなく科学的に証明し たいと考えている。
キーワード：人中診法、望診、中医文献システマ ティック・レビュー、診察法、 evidence-based 
10-F-14:48

\section{ドーゼと得気と鍼感の考察（技術 転移)}

兵庫地方会

田中重喜

【目的】平成6年から「ドーゼの標準化」「銊感 得気の相関」について、これまで6回関係学会で 口演した。その結論のひとつとして、1施術にお いて日本は中国の 24 倍ドーゼを要する事が明ら かになった。そこで本口演ではその原因の背景と して専門書の記載内容が関与するものと考え、日 本と中国で使用されている標準教科書を対象に、 経穴に関する記載事項、刺鍼法、施尒法などにつ いて比較検討した。

【方法】日本および中国の標準教科書を対象とし た。日本の標準教科書として東洋療法学校協会編 の『経穴概論』と『鍼尒実技』を、中国のものと して『中国針众学概論』（三中医学院研究所編） と『針尒学』（上海中医学院編）を採用した。調 査項目として、取穴法、筋肉・血管・神経、施術 部位、刺鍼法、刺鍼深度、刺銊方向、銊感、施尒 法、施尒の可否などについて調査した。

\section{【結果】}

(1)日本の経穴に関する情報は位置情報が主である のに対して、中国のそれは臨床に則した情報 （深さ、得気、方向、主治など）が主であった。

(2)日本の教科書には刺銊深度や刺入方向の記載が 無いことから、医療過誤のリスクが高くなるこ とが予想される。

(3)日本では経穴への刺銊時に生ずる鍼感について の記載がない。

(4)日本の刺鍼においては無痛刺入を重視する傾向 にあり、しかも浅刺で多数穴に刺鍼する傾向に ある。

【考察と結語】以上の結果から、中国で示されて いるように日本においても経穴への刺鍼の深さ・ 方向・鍼感・主治などについて標準化をはかり、 臨床に則した目的的機能情報を重視すべきである。 そうすることによって臨床効果を高め、医療過誤 を未然に防ぐことが可能となる。中国針食術は標 準化医療技術システムとして機能していることか ら、日本への技術導入に際しては、一部を取り入 れるのではなく、原型をそのまま移入することが 肝要である。そういったことから、今後は経穴に 関する機能的情報を明確に記載することが求めら れる。

キーワード : 鍼感、得気、ドーゼ、標準化
10-F-15:00

手指先の経穴・非経穴から検出さ れる極微弱生物フォトン発光計測 について

東北工業大学情報処理技術研究所 - 宮城地方会

神 正照

【目的】人差し指から手の甲に分布している、経 穴・非経穴から検出される極微弱生物フォトン発 光測定を行い、生物フォトン発光強度の比較を行つ た。経穴・非経穴では生物フォトン発光に差違が あることが認められた。その結果、経穴の方が生 物フォトン発光強度が高いことが確認されたので 報告をする。

【方法】今回は、人差し指の未端から指の付け根 の所にある経穴・非経穴を測定し、それぞれの生 物フォトン発光強度を調べた。測定時間は1ケ所 それぞれ100秒間行った。

測定前は手と指先をきれいに洗浄し、外部から の光を完全に遮光し測定を行った。測定人数は、 学生（20代）男子5人である。

【結果】測定の結果、経穴と非経穴では生物フォ トンの発光特性がそれぞれ異なることが観測され、 指先の爪の生え際にある経穴の方が生物フォトン 発光強度が高くなっていることが計測された。人 差し指先にある経穴（商陽穴）部位で観測された 生物フォトンと非経穴の（指の腹）を比較した結 果、経穴側の方が多く発光していることが確かめ られた。

【考察】手の指先から検出される生物フォトン発 光強度は、測定の結果経穴には左右差があること が確かめられた。指先に分布する経穴においては、 右手の経穴の方が発光強度が高いことが観察され た。

【結語】同様な方法で測定した結果、左右の腕・ 手首の経穴で測定した生物フォトン発光量は、右 手側の方が発光量が多く測定された。これまで測 定してきた結果を比較すれば、上腕も左右差が有 ることが実験で確かめられた。

キーワード：経穴、非経穴、発光強度、生物フォ トン発光 
10-F-15:12

\section{人体フォトンの日中変化について の検討}

専門学校浜松医療学院

林昇、竹村千冬、山下典秀 竹下文朗、下村壯介

【目的】生物は生きている間、常に微弱なフォト ンを外部へ放出していることがすでに知られてい る。前回我々は鍼刺激による人体フォトン反応に ついての検討を報告した。その検討の中で我々は 人体から放出するフォトンの量には個人差があり、 同一のモデルでも時間帯によって、あるいは生理 状態によって異なることに気がついた。今回、我々 は、日中に人体経穴から放出するフォトン量の変 化と、運動前後におけるフォトン量の変化につい て検討した。

【方法】1）被験者の手三里、合谷、手掌を遮光 テープで遮光し、直射日光を避け、弱い自然光の 部屋で普通の事務仕事（パソコンや読書）をしな がら、朝9時から夕方6時まで、1時間毎に手三里、 合谷、手掌のフォトンをそれぞれ5分間測定した (測定方法は前回と同じく、暗室で行う)。2）夕 方6時から20分間運動し、運動後のフォトンを測 定した。以上の平均值をグラフにして分析した。

【結果】朝9時から夕方 6 時にかけて、手掌、合 谷、手三里ともにフォトン量の変化は波状を呈し、 朝9時頃はフォトンの量が高く、昼に向かって徐々 に低下する。昼過ぎに再び上昇し、2 時と 3 時の 間にピークとなり、その後また徐々に減ってくる。 夕方6時頃低下した時点で20分間運動をした後、

フォトン量が再度上昇する。日中、手三里、合谷、 手掌フォトン量の変化曲線が平行して移行するも のではなく、それぞれ異なった波線をなしている。

【考察・結語】結果から見ると、朝9時から夕方 6 時の間、手三里、合谷、手掌のフォトン量の変 化には二つの高值点があった。一つは朝初回測定 の頃、もう一つは昼食後しばらく経過してからで あつた。二つのピークはともに食後に現れた。ま た、フォトン量が低下した時点で運動をした場合、 フォトン量の上昇が見られた。この結果から日中 フォトン量の変化が体の代謝レベルに関連してい るのではないかと考えられる。経穴間フォトン量 の異なる変化は東洋医学におけるいわゆる気の変 化との関連があるのではないかと思われる。

キーワード：フォトン、経穴、代謝、気

\section{$10-\mathrm{F}-15: 24$ \\ 耳針治療の臨床効果と橈骨動脈反 射}

新肥満研究所・東京地方会

池園悦太郎

【目的】第51回本大会において、肥満治療にお ける耳針の効果として、胃点の刺激が満腹感を催 起し、視床下部における摂食中枢の抑制物質が増 加する事を報告した。肥満治療では、胃点の他に、 味覚を変化させる神門点、苛立ちを抑える脳点に 置針した。また喘息、アレルギー性皮膚炎を合併 する患者には、耳介のアレルギ一点を探索し、橈 骨動脈の変化を記録した。

【方法】Paul Nogier の脈診は、左手首の関の 脈診を用いている。この脈診法を客化する為に日 本コーリン社製の圧トランスジューサーを用いて、 橈骨動脈波をアナログで測定し、これをデジタル 化して解析をおこなった。アレルギー点は、耳介 の頂上部耳輪の縁の下にある。ツボ探索には、 Nogier が作製した Agiscop DT を使用し電気抵 抗值が $1 / 2$ に減弱する点を、患者が知覚しない 3-5 $\mu \mathrm{A}$ 電流で探索し橈骨動脈波の変化を測定した。

【結果】患者は30歳、BMI=29.4の女性で日光ア レルギーがあり、四肢のどの部位でも日光にあた ると掻みを伴う赤い小丘疹ができた。Agiscop DTを用いて、アレルギーポイントを探索し、耳介 頂上部で耳輪の内側に反応点を発見した。探索時 における橈骨動脈の最高血圧は、対照時 $97.16 \pm$ $3.09 \mathrm{mmHg} \quad(\mathrm{n}=52)$ より $101.66 \pm 3.26 \mathrm{mmHg}$ $(\mathrm{n}=57)$ に上昇 $(\mathrm{p}<0.001) 、 \mathrm{PP}$ 間隔は 759.23 $\pm 13.28 \mathrm{msec} よ り 730.64 \pm 12.16 \mathrm{msec}$ に下降 $(\mathrm{p}<0.001)$ 、脈圧は $51.68 \pm 1.24 \mathrm{mmHg}$ より $53.51 \pm 123 \mathrm{mmHg}$ に上昇 $(\mathrm{p}<0.001)$ 、 upstroke（脈圧 / DIA $\rightarrow$ SYS）時間は 326.746士 $19.21 \mathrm{mmHg} / \mathrm{sec} よ り 346.28 \pm 21.13 \mathrm{mmHg} /$

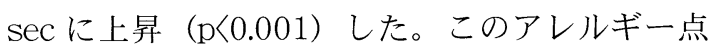
に円皮針を刺入留置した結果日光アレルギーは軽 快した。

【結語】耳介には、満腹感催起、味覚変化、アレ ルギ一改善点、腰痛点などがあるが、ツボ探索器 Agiscop DT を使用し、反応を橈骨動脈反射で 確認する事が望ましい。

キーワード : Paul Nogier、脈診、Agscop DT、 橈骨動脈波、アレルギー 


\section{0-F-15:36 \\ 脉状診と血圧との関連研究}

愛知地方会研究部情報・評価班

皆川宗徳、石神龍代、堀茂、中村弘典 田中法一、服部輝男、河瀬美之、絹田 章 中村高行、黒野保三

【目的】黒野等は、脉診の実態を客観的に引き出 す目的で、脉診と六祖脉との研究結果を第32回、 34回（社）全日本鍼尒学会学術大会において報告 した。六祖脉を基本として、脉状診と血圧との関 連を、正常血圧群、高血圧群、低血圧群に分けて 比較検討したので報告する。

【方法】平成 13 年 7 月より 12 月までに 10 治療院 に来院した患者に対し、血圧測定、脉診を行った。 脉状診は、浮・沈・遅・数・滑 - 濇に分類し、血 圧測定データから、正常血圧群、高血圧群、低血 圧群の3群に分類した。さらに高血圧群を拡張期 血圧（以下DBP） 90mmHg 以上をパターン、収 縮期血圧（以下SBP） $140 \mathrm{mmHg}$ 以上をパター ン2、DBP90mmHg 以上かつ $\mathrm{SBP} 140 \mathrm{mmHg}$ 以 上をパターン 3 とした。低血圧群を DBP60 $\mathrm{mmHg}$ 以下をパターン1、 $\mathrm{SBP} 110 \mathrm{mmHg}$ 以下 をパターン2、 $\mathrm{DBP} 60 \mathrm{mmHg}$ 以下かつ $\mathrm{SBP}$ $110 \mathrm{mmHg}$ 以下をパターン 3 とた。

【結果】(1)多施設（10治療院）での集積結果は 243例となり、正常血圧群126例（52\%）、高血 圧群80例 (33\%)、低血圧群37例（15\%）となつ た。(2)高血圧群では、パターン2の割合が59\%、 低血圧群ではパターン2の割合が70\%と多かつた。 (3)浮・滑群では、正常血圧群59\%、高血圧群 47 \%、低血圧群 $28 \%$ と正常血圧群、高血圧群の割 合が多く、沈・滀群では、低血圧群 $31 \%$ 、高血 圧群 $16 \%$ 、正常血圧群 $6.7 \%$ と低血圧群の割合が 多かった。

【結語】脉状診と血圧との関連を正常血圧群、高 血圧群、低血圧群に分けて比較検討した結果、浮・ 滑群では、正常血圧群、高血圧群の割合が多く、 沈・濇群では、低血圧群の割合が多いことが判明 した。今後、脉状診と血圧の客観化として、パラ マコロトコフ音図との関連性も検討していきたい。

キーワード：脉状診、六祖脈、血圧
10-F-15:48

末梢血液像と中医弁証との相関に ついて

\author{
一脈診から血診へー
}

中城歯科医院・神奈川地方会

中城基雄

【目的】中医弁証を行う際、特に脈診において、 「何が」「どの様に」「脈状」に反映しているのか、 客観的に評価しうる明確な指標はなかった。今回、 演者はブラッドフォード末梢血液評価システム (アメリカンバイオロジクス社製、以下、BVPM と略す）を用いて、患者の血液像を観察し弁証と の相関を検討した結果、弁証の違いによって発生 する血流中の変化を初めて画像として捕らえ、興 味ある知見を得たので報告する。

【方法】歯科口腔疾患を主訴とする患者に対し、 中医学的な弁証と脈診を行い記録した。次いで、 患者の商陽穴より刺絡を行い、プレパラートに採 取しB VPM システムを用いて未梢血液象を顕微 鏡観察し、DVビデオレコーダーにて記録して、 弁証と脈診との相関を検討した。

【結果】(1)痰濁証（主訴：辺縁性歯周炎）の患者 に、特有の $50 \mu$ 大の血中脂質プラークを認めた。 (2)疾血証（主訴：歯髄壞死）の患者に、粘調度増 加による赤血球の巨大集合体を認めた。(3)肝腎陰 虚証（主訴：急性歯槽膿瘍）の患者に、変形した ウ二状赤血球を多数観察した。

【考察】従来、血液中には主に血漿成分と血球成 分が含有していると考えられているが、実際の生 体には、それ以外の物質が多く流れている事は、 BVPMシステムの客観的評価法によって確認され ている。演者は、この様な体質の変化によって発 生する、典型的な末梢血液像が中医弁証との間に 何らかの相関が内在している事に着目した。すな わち、こうした病理産物が、生体にとっての「実」 な部分であり、「邪の正体」ではないかと類推す る物であり、ひいては、脈状に反映している可能 性がある事も示唆するものである。今後は、さら に臨床的検討を進め、治療効果の判定も視野に入 れて、脈診から発展した新たな概念として「血診」 の有意性を考慮して行きたいと考える。

【結語】BVPM システムを用いて、患者の末梢 血液像を観察し、中医弁証との間に客観的評価法 へつながる相関を見出した。

キーワード : 末梢血液像、ブラッドフォード末梢 血液評価システム、弁証、脈診、血診 
10-F-16:00

\section{刺鍼手技と生体反応（第1報）}

一鍼の刺入深度の違いによる

末梢血流と筋内血液動態の影響—

明治鍼众大学臨床鍼尒医学 II 教室

田和宗徳、北小路博司

明治鍼尒大学健康鍼尒医学教室

矢野 忠

筑波医療技術短大

坂井友実

【目的】鍼刺激時の局所や遠隔部の血流の検討は、 これまで多くの報告がされている。しかしながら、 刺鍼手技と血流との関係についての報告は少ない。 今回演者らは、置鍼による刺入深度を変えたとき の刺激局所及び遠隔部の血流と皮下深層から笳肉 表層までの深部の血液動態の変化を検討した。

【方法】健常成人男子 6 名（平均年齢 24.2 才）を 対象とした。皮下血流はレーザードップラー血流 計ALF21を用い、深部の血液動態の変化は近赤 外分光計MCPD-2000を用い、それぞれのプロー ブを刺鍼部位（上巨虚）より $2 \mathrm{~cm}$ 離れた所に装 着した。また刺鍼側の足の第1指に指尖容積脈波 計を装着した。なお、実験に先立ち超音波画像診 断装置で皮膚の厚みを計測して各被験者の刺入深 度を決定し、皮下,筋肉内 $1 \mathrm{~cm}$ 刺入の置鍼を行つ た。容積脈波のデーターはポリグラフに入力した 後に、皮下血流はMacLab/8sに、それぞれオン ラインでデーターを保存した。近赤外分光計のデー ターは専用のコンピューターにて保存した。デー ターの解析は、MacLab/8sで容積脈波の1分間当 たりの積分值と皮下血流の平均值を算山し、近赤 外分光計のデーターは専用の多成分解析プログラ ムにて数值化した。以上の条件で刺鍼前、置鍼中、 抜鍼後10分間の測定を行った。

【結果と考察】容積脈波は筋肉内 $1 \mathrm{~cm}$ 刺入によ り置鍼中、抜鍼後に増加傾向を認めた。皮下血流 は、いずれの刺入でも実験開始から終了まで減少 傾向を認めたが、筋肉内 $1 \mathrm{~cm}$ 刺入において置鍼 中の值が置鍼前の值に、抜針後の值が置鍼中の值 に、復する傾向が見られた。深部の血液動態は、 いずれにも変化は見られなかつた。このことから、 容積脈波の変化は交感神経を介した血管反応を引 き起こしたと考えられた。一方、皮下血流及び深 部の血液動態にはあまり影響しないことが示唆さ れたが、被験者の中には深部の血液動態と皮下血 流が変化している例もあるので、症例を増やして 検討する必要がある。

【結語】置鍼の刺入深度の違いによる変化を検討 した結果、筋肉内 $1 \mathrm{~cm}$ 刺入時の血管反応以外に は変化を認めることは出来なかつた。

キーワード：鍼、近赤外分光法、血流、刺銊手技
10-F-16:12

\section{近赤外線分光法による鍼刺激時の 筋組織血液量変動の検討}

一刺鍼部位の違いによる血液動態—

東京医療専門学校

大久保正樹、坂本 歩、村居眞琴、斉藤秀樹 鹿屋体育大学 浜岡隆文

東京医科大学衛生学公衆衛生学教室

勝村俊仁、下光輝一

【目的】本研究では、近赤外線分光法の測定部位 の中心に鍼刺激を行った場合と測定部位外に鍼刺 激を行つた場合、僧帽筋筋組織における血液動態 がいかに変化するかを検討した。

【方法】被験者は健常成人16名（うち男子 2 名、 女子 14 名)、年齢は 23 歳 64歳（平均；35歳） であった。刺激部位は右肩上部の僧帽筋上部線維 の筋腹とした。筋組織の血液量 (BV) は、オム ロン社製 $H E O-210$ を用い 0.2 秒毎に測定した。分 離型プローブの送光部と受光部の距離は $4 \mathrm{~cm}$ と した。刺激部位は、送受光部の中心になるように 設定した場合 (中央部) とプローブの遮光シート 外縁に設定した場合（外側部）の2部位に行った。 鍼刺激は、測定開始 3 分後から雀啄術を 2 分間行 い、ひびきを感じた時の時間を記録した。更に測 定開始 15 分後に僧帽筋最大随意収縮（肩挙上） を5秒間行った。僧帽筋内血液量の評価は、肩挙 上後の血液量変化の最大值に対する刺激時の血液 量変化の割合（\%)で行った。

【結果】血液量は、中央部・外側部ともに刺鍼前 に比べて刺激中は有意に増加した（p<0.0001）。 刺激中最大值の比較では、外側部 $(13.9 \pm 30.8 \%$, 平均 $\pm \mathrm{SD})$ に比べて中心部 $(50.0 \pm 18.6 \%)$ は 有意に血液量が増加した（p<0.001）。また、ひ びきと血液量の間には相関関係はみられなかった。

【考察と結論】近赤外線分光法では、送受光部の 距離 $(4 \mathrm{~cm})$ の半分を半径 $(2 \mathrm{~cm})$ とした半球状の 深さを測定している。これまでの実験で中心部の 刺銊によって測定部の血液量が増加することが認 められている。本実験では、刺激部位である外側 部は中央部 (測定部位の中心)から $3 \mathrm{~cm}$ 離れてい た。従って、測定部位から少し離れた外側部の鍼 刺激による血液量の増加は、神経系を介した筋組 織の血管床の拡張によるものと考えられる。

キーワード：近赤外線分光法、僧帽筋、血液量、 中央部、外側部 
$10-\mathrm{F}-16: 24$

\section{温冷刺激の局所皮膚温・熱流量に 与える影響（第2報）}

日本銊众理療専門学校 ${ }^{1)}$ 、

(財) 東洋医学研究所 ${ }^{21}$

小島孝昭 ${ }^{1,2)}$ 、小川 - ${ }^{1,2)}$ 、白石武昌 ${ }^{2)}$

【目的】生理的反応や機能障害は生体の約 $60 \%$ 以上を占める種々の体液の組成変化・循環障害を 反映している。このことから、ある種の刺激で機能 障害を発現している部位の体液の“流れ”を調整 することによって、その正常化が可能であるかを 試みた。換言すると全身の治療を目的とした血・ 津・液の流れを調整しようとする試みである。こ の方法を “BOFCOORT (Body Fluid Coordination Treatment)”として提唱した。 今回は軽〜中等度の腰痛患者の皮膚温と単位時間 当たりの熱流量（熱流束； $\mathrm{W} / \mathrm{m}^{2}$ ）を指標とし検 討した。

【方法】被検者は informed consentを得た男性 30名、女性29名、軽度〜中等度の腰痛患者、平 均年齢約29 (19４9) 歳で、刺激はアルミ製の温 球 (直径約 $2 \mathrm{~cm}$ 、温度約 $42 \sim 45^{\circ} \mathrm{C}$ ) ・冷球（直 径約 $5 \mathrm{~cm}$ 、温度約 $20^{\circ} \mathrm{C}$ ) を木製握棒で連結した 温球と冷球で皮膚面を交互に温・冷刺激した。患 側・健側の腎俞近傍の皮膚温はthermistorで、熱 流束と共に連続測定し、 1 秒毎、約 60 分間 PC-HD に記録した。併せてサーモグラフと同時 計測し、刺激・治療（BOFCOORT）前後の変化 を大杼周辺と比較検討した。

【結果】腰痛患者の患側腎俞近傍の皮膚温 (33.9 $\left.\pm 0.2^{\circ} \mathrm{C}\right)$ は健康者 $\left(33.3 \pm 0.2^{\circ} \mathrm{C} 、 \mathrm{n}=10\right)$ より高 かった（p<0.05）。また大杼近傍 $\left(34.4 \pm 0.2^{\circ} \mathrm{C}\right)$ に比し低かった（p<0.05）。BOFCOORT 後の治 療効果は、腎俞近傍の皮膚温は熱流束の変化に伴 い低下し、大杼では上昇させるなどの成績を得た。

【考察と結語】今回軽度〜中等度の腰痛患者に対 する BOFCOORT 効果は、興味あることに患部 の体液の“流れ”が調整され、結果的に熱流束の 変化に伴う温度変化が得られるという未知の所見 を得た。このことは未病を治し自然治癒力を六め る BOFCOORT の有効性を示唆するものであろ うか。今後、他の疾患等に試行し詳細に検討する。

キーワード : 温泠刺激、皮膚温、熱流量、 BOFCOORT、腎有
$10-\mathrm{F}-16: 36$

\section{鍼炎治療による自律神経反応の検 討}

関西鍼尒短期大学鍼尒学臨床教室

坂口俊二、中吉隆之、池藤仁美、川本正純

【目的】我々はこれまで、鍼众治療（以下、治療） による生体反応を末梢循環動態や自律神経機能を 評価する加速度脈波（SDPTG）を用いて観察し てきた。今回は、SDPTGに皮膚通電電流量 $(\mathrm{ECV}) 、$ 血圧・脈拍測定を加えて、治療による 自律神経反応を検討した。

【方法】対象者は、口頭にて同意の得られた本学 附属鍼炎治療所の患者58名（男20名、女38名、 平均年齢58.6歳）であった。対象者には仰臥安静 にて問診、SDPTG、ECV および血圧測定後に各 症状に対する治療を行い、終了後に再度 SDPTG と ECV を測定した。SDPTGは、加速度脈波計 SDP-100（フクダ電子製）を用いて右第2指で測 定し、ECVは、ノイロメーターマスターチャー トAD（K.K.データグラフ製）を用いて、手足 12 か所、左右計 24 所の代表測定点で測定した。 血圧は右上腕で聴診法にて測定し、22名は治療 終了後に再測定した。なお、測定環境は、室温 $24.3 \pm 1.2^{\circ} \mathrm{C}$ 、湿度 $56.1 \pm 8.9 \%$ であった。

【結果】対象者を降圧剂を服用している群（「服 用群」）18名とそうでない群（「非服用群」）40名 に分類した。「服用群」では脈拍数のみが有意に 減少したのに対し、「非服用群」では脈拍数と ECV の有意な減少、SDPTG の d/a 值の有意な 減少と PTGAI 值の有意な増加がみられた。22名 の治療後の血圧に有意な変化はみられなかつた。

【考察】降圧剂服用の有無に関連しない治療後の 脈拍数減少と「非服用群」にみられたECVは、 副交感神経機能充進を示し、それに誘起された交 感神経機能克進が、 $d / a$ 值減少とPTGAI值増加と いう機能的な動脈壁の緊張状態を表したものと考 えられる。

【結語】鍼众治療による自律神経反応は、降圧剤 服用の有無が影響し、降圧剂を服用していない者 では、副交感神経機能の亢進とともに交感神経機 能の亢進による機能的な動脈壁の緊張状態を作り 出すことが示唆された。

キーワード：鍼尒治療、自律神経、加速度脈波、 皮膚通電抵抗、血圧 
10-F-16: 48

\section{反復刺激によるSSR・SFRの habitua- tion について}

関西鍼众短期大学東洋医学臨床教室

木村研一、黒岩共一、増田研一、若山育郎

【目的】我々は本学会でsympathetic sweat response (SSR) • sympathetic flow response (SFR) が鍼刺激によって抑制されることを既に 報告した。しかし、SSR、SFR は慣れ現象 (habituation) による修飾を強く受けるため、そ の再現性について指摘されている。そこで今回、 反復刺激によるSSR・SFRにおける habituation の発生機序について microneurography を用い て皮膚交感神経レベルでの検索を行った。

【方法】対象は神経学的異常の無い健常成人 14 例とした。実験は室温 $25^{\circ} \mathrm{C}$ 、湿度 $40 \%$ の検査室 で行った。被験者は安静仰臥位とし室温順応 30 分後、右側手関節部正中神経を経皮的に 20 秒以 上の間隔を置いて duration $0.2 \mathrm{msec}, 60 \mathrm{~mA}$ の矩 形波電気刺激を 10 回行い、左側肘部正中神経か ら microneurography を用いて反射性皮膚交感 神経活動（SSNA）を記録し、同時に換気カプセ ル法を用いて母指掌側基節部から SSR、レーザー ドップラー血流計を用いて示指指尖部から SFR を記録した。

【結果】反復刺激により SSNA バーストの潜時 は変化しなかったが、振幅は1回目に比較し2回 目以降は有意な低下を示した。同様に、SSR も2 回目以降は有意な反応性の低下を認めたが、SFR は有意な変化を示さなかった。また、SSR は SFR に比較すると有意な反応性の低下を認めた。

【考察と結語】2回目以降に SSNAバースト振幅 が低下したことから habituation による交感神経 出力の低下が皮膚交感神経レベルで示唆された。 また、SSR が SFR に比べ、有意な反応性の低下 を示したことは habituation による発汗運動神経 出力の低下と汗腺の活動性の低下により SSR の 反応が2回目以降、著しく漸減したと推測した。

キーワード : SSR、SFR、SSNA、 habituation、 microneurography

\section{P-D-15:00 \\ 放送大学学生および教職員における 健康と理療の関心度について}

東京都立八王子盲学校

宮村大地

【目的】放送大学は平成 13 年 2 学期現在で学生数 約 9 万人が学ぶ教養学部から成る通信制大学であ り、平成 13 年 4 月より大学院が設置された。在学 生の年齢や職業は様々であり、それに伴い家族構 成や生活習慣、嗜好なども同様に多種多様である と考えられる。今回、理療（はり、きゅう、あん 摩マッサージ指圧）の受療経験の有無や既往歴、 現病歴の有無、衛生学・公衆衛生学など理療科科 目分野に関連する生活に関する基礎的な情報を客 観的に調査分析し、理療に対する印象、ストレス、 現在の体調など回答者の健康に関する事項を記述 してもらいまとめた。

【方法】年齢、職業、嗜好、趣味、運動習慣、現 病歴、既往歴等と、はりきゅうマッサージの印象 (イメージ)、受療経験の有無、種類、場所等を問 う選択記述複合形式のアンケートを作成し平成1 4年7月 25〜26日に東京多摩学習センター、同年 7月27〜28日、8月15日に東京世田谷学習センター、 同年8月17日に埼玉学習センターで切手付き返信 用封筒とアンケート用紙を総計124通配布した。

【結果】学生、教職員合わせて84名（男性30名、 女性54名）から回答が得られた。平均年齢は 47.6 歳（男性50.5歳 女性45.8歳）で、理療の受療経 験「あり」は53.6\% (45名)、なしは46.4\%（39 名) であった。中でもマッサージが47\% (40名) で割合が高く、以下はり $29.7 \%$ (25名)、きゅう 9.5\%（8名）であつた。はりの印象については、 「良くなる(なりそう)」・効果がある(ありそう)」、 「痛い（痛そう）」、きゅうは無回答、「熱い（熱そ う)」、マッサージは「気持ち良い」・「効く」・「良 くなる」、無回答の順で多く、受療経験のある中 で4名が定期的に受療していることがわかった。

【考察・結語】マッサージの受療割合が高く、治 療院以外にクイックマッサージやエステ、スポー ツクラブなど最近開拓された場所での受療がある ことがわかった。はりに対して「痛い」よりも 「効果がある・良い」といつた正のイメージが多 かったことがわかった。

キーワード : アンケート、理療、受療経験 
1P-D-15:14

鍼炎をもっと身近なものに（1）

一病院勤務看護師の愁訴と鍼众に関するイメージ

の調査一

兵庫県立東洋医学研究所

外間宏昌、吉田剛典、伊達敬太郎

石川 亨、曽 炳文

兵庫県立尼崎病院

植田英子、石谷明子、近藤優子

【目的】兵庫県立東洋医学研究所は同県立尼崎病 院に併設されている。そのため看護師が局こりや 腰痛の改善を求めて鍼尒治療を受けたり、病院受 療中の患者が看護師の勧めによって来所すること もある。しかしそういつたケースは必ずしも多く はない。今回我々は、同病院勤務看護師の鍼尒に ついての理解を深めることを目的として、看護師 の有する鍼众適応症状と鍼众受療経験に関するア ンケート調査を行った。さらに希望者に対しては、 鍼の体験治療も実施したが、不参加者を対象とし て鍼众に対するイメージ調査もあわせて行ったの で報告する。

【方法】対象とした看護師 417名（男6名・女 411 名、20６0歳）に対し、肩こり・腰痛・膝 痛およびその他の自覚症状の有無と鍼尒受療経験 についてアンケート調查を行った。そのうち体験 治療不参加者181名については、不参加の理由を 無記名調査用紙にて回答してもらった。

【結果】有効回答数 329 名 $(79.8 \%)$ について、 有訴症状を有するものは、局こり $80.8 \%$ 、腰痛 $60.7 \%$ 、膝痛 $18.5 \%$ 、その他としては頭痛、下 肢の浮腫・だるさなどが多かつた。鍼尒経験につ いては「経験あり」が20.7\%、「経験なし」が $79.3 \%$ であった。年齢による症状の違いについ ては、50歳代に膝痛を有する傾向がみられた （ $\chi^{2}$ test）。体験治療不参加の理由としては「自 覚症状がない」「鍼众に関心がない」「怖いという 印象がある」などが上位を占めた。

【考察と結語】病院勤務看護師の多くが鍼尒適応 症状を有するが、鍼众治療経験者は予想外に少な いことが分かった。年齢・勤務内容による自覚症 状の差異は、50歳代に膝痛を有する者が多かつ た以外は特に一定の傾向はみられなかった。体験 治療不参加の理由から鍼众に対する意識を推察す ると、今後病院勤務看護師に対して鍼众をアピー ルする機会をより多く提供する必要性があると思 われた。

キーワード : 病院勤務看護師、鍼众受療経験、ア ンケート調査
1P-D-15:28

鍼炎をもっと身近なものに（2）

一短時間の鍼「簡易鍼」による肩こり軽減効果の 検討一

兵庫県立東洋医学研究所

吉田剛典、外間宏昌、伊達敬太郎

石川 亨、曽 炳文

兵庫県立尼崎病院

植田英子、石谷明子、近藤優子

【目的】鍼治療は肩こりに対して有効な治療手段 の1つである。しかしながら、鍼に対する恐怖感・ 時間的制約・経済的問題などの理由から、実際に 鍼众治療を受けるのをためらっている患者もかな り多いことが想像される。またこれらは、鍼众適 応と考えられる患者に対して、医師が積極的に鍼 治療を钦めにくい理由ともなっている。

この問題を解決し鍼尒をより身近なものにするた め現在当診療所では、軽刺激による局所主体取穴・ 短時間による治療システム（以下「簡易鍼」）の 導入を検討している。これを前提として、今回兵 庫県立尼崎病院看護部の協力を得て、簡易鍼が有 用であるかどうかを検討したので報告する。

【方法】対象は兵庫県立尼崎病院勤務の看護師の うち、肩こり症状を有する簡易鍼希望者 134 名 （34.5 \pm 10.7 歳）である。方法は対象者に座位に て、40 16 号ディスポ針を用いて、項頸部・肩 背部主体に、浅刺・軽刺激による10分間の治療 を、約 1 週間の間隔をおいて 2 回行なつた。対象 者には治療前・直後・2日後の自覚症状の数值ス ケール (numerical scale:NS) と治療後の感覚 や鍼治療に対する印象などの調査項目について記 録してもらった。

【結果】症状の数值スケールについては記載漏れ を除いた 125 名において、鍼治療前後で有意な低 下がみられた（p<0.01）。「鍼が心地よい」と感じ たものは64名であった。治療時間については 「初めての体験で手軽で良かったが、10分では物 足りない」という意見も多かった。「今後続けて 治療を受けたい」とした者は71名であった。

【考察と結語】簡易銊は肩こりの自覚症状を軽減 し得ることが確認できた。今後効果の持続日数の 延長や他症状への適用拡大を検討していく必要が ある。軽刺激・局所主体の治療体験を通じて鍼に 対する恐怖心や不安感を払拭し、患者にとって鍼 众治療がより身近なものになるための有用な手段 になり得ると考えられた。

キーワード：肩こり、簡易鍼、数値スケール 
$1 \mathrm{P}-\mathrm{D}-15: 42$

\section{鍼炎技術研修における時系列分析 法の運用}

一えひめ東医研における試み一

愛媛県立中央病院東洋医学研究所

谷口一也、山見 宝 山岡傳一郎、光藤英彦

【はじめに】愛媛県立中央病院東洋医学研究所で は、平成 9 年度より研修プログラムを導入し、鍼 炎師の卒後研修を試行している。この研修におい て時系列分析法を取り入れている。その事により、 研修生がチーム医療の中で効率良く臨床研修が行 えると考えている。今回、具体例を示してその一 端を報告する。

【具体例】ポスターにて症例の詳細を掲示する。 要約は以下の通りである。器質的には問題が無い 之診断されている13才の夜尿症の症例。時系列 分析を行う事により以下の事が明らかになった。 (1)夜尿は一次性で比較的軽症であると考えられる。 (2)転居を契機に、咳・風邪引きやすさ・頭痛等を 発症している。(3)夜尿症である事が頭痛を増悪さ せているのではないかと考えられる。(4)兄弟・両 親ともに夜尿症の既往は無い。(2)・(3)に注目する と、本症例は、転居に伴う生活環境の変化によっ て固定された心身症ではないかと考えられる。

【結語】医学領域での時系列分析法とは、既にこ れまでの医療での歴史的認識である、既往歴・家 族歴・現病歴と矛盾するものではなく、むしろこ れらを包括し、それぞれの歴史を並列・比較する ように工夫したものである。この時系列分析法の 運用により、(1)病人を全人的に捉えられる。(2)家 庭・社会環境における病人の位置付けの理解。(3) 病人を中心としたチーム医療の中での共通の認識 が得られるため、効率良く研修が行えると考える。 しかし、時系列分析法の運用には、(1)治療相談力ー ドからの情報収集、(2)面接技術、(3)生活上の出来 事と病症との関連性の掌握等のテクニカルノウハ ウが必要となり、そのトレーニングを研修プログ ラムに導入する事が不可欠であると考える。

キーワード：鍼尒技術研修、時系列分析法、チー 厶医療

\section{P-D-16:00}

\section{ネットワーク利用による蔵書検索シ ステムの構築}

後藤学園ライフエンス総研情報科学研究部 ${ }^{1}$

岩手医科大学歯学部口腔生化学講座 ${ }^{2}$

稲木雅人 ${ }^{1}$ 、高松邦彦 ${ }^{2}$ 、高岡 裕 ${ }^{1}$, $)$

【目的】図書館等の蔵書検索は、コンピュータを 利用したものが増えてきている。学校内のパーソ ナルコンピュータ (PC) から蔵書を直接検索で きれば、作業効率の向上と、それに伴う教育の質 の向上が期待され、さらには生徒の自学自習にも 役立つ。昨年本大会で報告したように、後藤学園 はインターネット接続とサーバ群を独自に管理運 営しており、鍼尒教育に積極的に利用してきた。 今回、本校が所有しているサーバ上に図書検索シ ステムを構築、校内既設の Windows や Machintosh 等の PC から、Web ブラウザ利用の 検索を可能にしたので報告する。

【方法】蔵書デー夕の管理には Micro Soft 社の MS-Access を用いた。検索用データは、データ ベース標準形式の一つである CSV 形式を利用し、 その際変換プログラム (Perl (Ver.5.005_02) 言語）を作成することで文字コードの問題を解決 した。Unix サーバには当校既設のSun Microsystems 社製 Enterprise250に、Apache （Ver.1.3.27）をインストールして Web サーバと して使用した。そして、検索結果は Web ブラウ ザで閲覧できるようにした。

【結果/考察】この蔵書検索システムが完成した ことで、直接教員自身の PC から蔵書を検索でき るようになった。その結果、教職員が教材を作成 するときに、作業効率が向上した。また、学生も 図書館に設置された PC を利用し、同様の恩恵に あずかった。また検索用 PC のソフトは Web ブ ラウザであり、PCの機種に非依存のため、メン テナンスはサーバ側のみでよい。通常、このシス テムの構築には、高価なソフトウェア購入か多額 の開発費が必要になる。しかし、今回我々は短時 間かつ低コストで開発を終了できた。現在、本学 園内（東京校及び神奈川校）からのみ検索が可能 になっている。今後は、インターネット上で公開 することも検討したい。

キーワード : 蔵書検索、インターネット、WWW 
1P-D-16: 14

\section{音声出力／認識を利用した対話型電 子カルテ入カシステムの検討}

筑波技術短期大学鍼众学科

筑波技術短期大学附属診療所
木村友昭

津嘉山洋
1P-D-16:28

鍼炎高等教育機関·大学院博士課程修 了後の動向調査

明治鍼尒大学大学院鍼尒学研究科

北出利勝、渡邊 泱、平澤泰介
【目的】これまでに我々は、音声認識を利用した 電子カルテ入力システムを試作し、カルテ入力の 効率化に役立つ可能性を指摘した。今回は、定型 的な所見入力のためのガイダンスを音声出力し、 音声で所見を入力する対話型入力システムを試作 し、その有用性について検討した。

【方法】対話型の所見採取のモデルとして、腰下 肢痛に対する日本整形外科学会（JOA）スコア を採用した。JOA スコアの各項目（計14項目） に対し、（1）各項目名、評価基準等を音声合成 により読み上げ、音声認識により結果を入力し、 データベースに保管する機能、（2）過去のスコ ア記録を読み上げる機能を満たすユーザーインター フェースを作成した。入力者の熟練度に応じて入 力効率を向上させるため、スコア項目のガイダン ス機能は音声コマンドによって省略可能とした。 本システムの開発には Visual BASIC 6.0 (Microsoft 製)、合成音声エンジンには TTS 3000 (Lemount\&Hauspie製)、音声認識エンジ ンには AmiVoice4.0（Advanced media 製）を 使用した。ハードウェアはパーソナルコンピュー 夕（SONY 製 PCG-C1VJ/BP） とマイクロホン 付ヘッドホンおよび自家製 USB ペダルで構成し た。

【結果と考察】項目名とその詳細説明が音声出力 されることにより、対話形式でスコアの入力が可 能であった。さらに、過去のスコアを音声で参照 することが可能となった。以上の特長から、本シ ステムがディスプレーによる情報の確認が困難な 視覚障害者のための定型的力ルテ所見の入力支援 システムなどに有用であると考えられた。

キーワード：電子カルテ、ユーザーインターフェー ス、音声認識、対話型、JOA スコア
【目的】本大学院鍼炎学研究科は、博士前期課程 (修士課程; 2 年間) が、鍼尒医学における研究 能力または高度の専門性を要する職業などに必要 な能力を養う (以下、マスター)。また、博士後 期課程（博士課程；3年間）は、研究者として自 立して研究活動を行い、専門的な業務に従事する に必要な高度の研究能力を養うこととしている (以下、ドクター)。そこで、マスター、ドクター 両者の修了時の進路とその後の動向を知るために 調查した。

【方法】マスターは1991年に開設され、修了年 は1993年であり 2002 年までの 10 年間を、ドクター は1994年にスタートして修了年は1997年であり 2002年までの6年間を調査した。調査項目は次の 通りである。マスターおよびドクターの進学先と 就職先について、現在の立場において大学院教育 が生かされいるかどうか (教育、臨床、研究)。

【結果】マスター修了者は1993年から10年間、 合計75名（男：57名、女：18名）であった。進 学の内訳はドクターへ進んだ者が44名（この内、 6名は他の大学院)、教員養成科が3名、本学研修 生が3名、海外留学（二ュージランド、米国）が 2 名であった。就職の内訳は病院、鍼尒院が 11 名、 教員が8名、開業が2名、その他が2名であった。 ドクター修了者は 1997 年から6年間、合計 22 名 （男：18名、女：4名）であった。就職の内訳は 教員が 20 名、研究生が1名であり、その他が 1 名 であった。

【考察と結語】わが国最古の医学全書である『醫 心方』を編纂した丹波康頼は、鍼博士・医博士で あった。大学院ドクターコース修了者は「銊尒学 博士」という名の学位記を授与される。同博士が 誕生した1997年は医聖・康頼が永眠して1002年 後のことであった。なお、課程博士ではない論文 博士は現在、5名が鍼尒学博士を取得している。 マスター修了者はドクターへ進学する者が過半数 を占めた。本学に限らず他大学もあった。教員と して就職する比率が高かった。ドクタ一修了者は ほとんどが教員になっていることが分かった。

キーワード：鍼尒高等教育機関、大学院教育、鍼 众学博士、論文博士、調査 


\section{P-D-16: 42 \\ 鍼炎の動物実験における実験条件の 文献による検討}

関西鍼众短期大学鍼尒学基礎教室

\author{
山崎寿也、楳田高士、吉備 登 \\ 北村 智、錦織綾彦
}

関西鍼尒短期大学生理学教室穴田靖之

【目的】鍼尒のメカニズム解明のため、多くの動 物実験が行われている。実験の条件は、その結果 に大きな影響を与える。そこで、どのような条件 で行なわれているかを、日本国内で発刊されてい る文献について調査を行い、検討を行つた。

【方法】1982〜2002年間の文献を対象に、キー ワードを「動物」及び「銊」「動物」及び「尒」 とし、「医学中央雑誌刊行会」から検索を行った。 項目としては、動物の種類、性別、週齢、体重、 麻酔剂の種類や使用量、施術部位、銊の種類、太 さ、長さ、パルスの使用、周波数、波形、電流、 電圧、炎については艾炷の大きさや壮数等につい て分析を行った。

【結果】抽出した文献数は鍼文献64、众文献42、 鍼・炎両方を含む文献 12 の 118 文献が抽出された。 条件の記載のない文献も多く認められたが、動物 の種類ではラットの使用が最も多く（72文献：61 \%)、ついでマウス（23文献: 19\%)、ウサギ（14 文献: $12 \%)$ の順であった。麻酔は64文献で記載 があり、ペントバルビタール (28文献: 44\%)、 ウレタン（27文献：42\%）が多く使用されていた。 鍼の施術部位では、後肢が最も多く、ついで背部、 腹部、前肢の順であった。パルス使用は50文献 にみられ、周波数は $1 、 2 \mathrm{~Hz}$ が最も多く、波形、 電流、電圧等の全ての条件を記載した文献は少な かった。施尒部位は背部が最も多く、ついで腹部、 後肢、頭頂部の順であつた。艾炷の大きさは一定 ではなく、壮数については $1 \sim 3$ 壮が最も多く認 められた。

【考察と結語】動物実験の実験条件を調査、分析 したが、その条件は研究者に依り一定していなかつ た。異なる条件では結果に差が生じる可能性があ り、結果を他文献と比較検討する場合、適切であ るのかどうか疑問が残る。今後出来る限りこれら の実験条件の統一化が望まれる。

キーワード：動物実験、実験条件、鍼尒、文献

\section{P-E-15:00 \\ 四肢択一問題の解答方法と正答率に ついての検討}

明治東洋医学院専門学校

渡辺康晴、安藤文紀、田中 博、谷口和久

【目的】今回、はり師きゆう師国家試験で行われ ている四肢択一問題において、正答率の良い学生 とそうでない学生の間に解答方法に違いがあるか どうかを検証したので報告する。

【方法】対象は本校の第 1 鍼众学科 1 年と柔道整 復学科 1 年の学生で、平成14年度中に解剖学 III 履修した 219 名とした。使用した問題は、第1回 から第10回のはり師きゅう師国家試験および柔 道整復師国家試験問題とした。これらの問題の中 から、授業で学習した範囲（中枢神経系）に該当 する35問を抽出し、内容別に2回にわけて授業中 に学生に解答させた。学生には各問題の解答時に 解答方法を評価するよう指示した。評価は3段階 で、容易に解答が1選択肢に絞れた問題 $(\mathrm{A})$ 、選

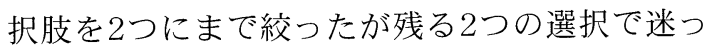
た問題 $(\mathrm{B})$ 、選択肢を $2 つ に$ 絞ることもできなかつ た問題 (C) とした。2回の模擬テストが行えなかつ た学生は解析から除外し、解析には209名のデー 夕を使用した。

【結果】全体の正答率は $52.2 \pm 19.0 \%$ (SD） で あった。学生を成績別に3群に分類した。35問中 25 問以上正解した高得点群（47名：正答率80.6 土7.3\%）では解答方法の評価と正答率に極めて 良い一致が見られた。一方、11問以下の正解数 であった低得点群（32名：正答率 $27.3 \pm 4.0 \%)$ では、解答方法を $\mathrm{A}$ と答えた問題で誤答を選ぶケー スが多かつた。その結果、解答方法を $\mathrm{A}$ 答えた 問題と解答方法を C と答えた問題の間で正答率に 大きな違いは見られなかった。12問から24問の 正解数であった中間群（130名：正答率48.1土 9.9\%）では、高得点群と低得点群の中間の傾向 を示した。

【考察と結語】高得点群では問題を解答すると同 時に、その解答が正答である可能性を正しく評価 できる傾向が見られた。一方で低得点群では、選 んだ解答が正答であるかどうかを認識できず、安 易に誤答を選ぶ可能性のあることが示唆された。

キーワード : 四肢択一問題、正答率、解答方法、 成績 


\section{P-E-15: 14 あん摩鍼炎実習教育の保険に関する 実態調査}

千葉県立千葉盲学校理療科

筑波技術短期大学鍼尒学科 ${ }^{2}$

箕輪政博 ${ }^{1,2)}$ 、形井秀— ${ }^{2}$

【目的】平成元年の厚生省の指導要領の改訂をう けて、専門学校では臨床教育の充実が急務となつ てきている。しかし、臨床実習中の事故等の対策 についての実態は明らかでない。そこで、あん摩 マッサージ指圧鍼尒（以下あん摩鍼尒とする）教 育の臨床実習に関する保険（主に賠償責任保険）

についてアンケートによる実態調查を実施したの で報告する。

【方法】調査対象は大学を除く全国のあ九摩鍼众 教育機関 (以下学校とする)、盲学校61、視力障 害センター6、専門学校等54の合計 121 校とし、 調査期間を平成 14 年 7 月 9月とした。アンケー 卜は選択と記述形式で行い、回答は記名式とした。 内容は施設や指導の実態、衛生面・安全面や保険 などを大項目 $\mathrm{A} \sim \mathrm{E} に わ け$ 全質問数を 49 問とし た。本発表では特に保険問題に焦点を絞つて報告 する。

【結果】回答件数は 121 校中 100 校で、有効回答 率は82.6\%であった。実習の保険に関して民間保 険会社と契約している学校は48校で、契約して いない学校は36校であった。契約保険会社では 総加入校数 52 校のうち A 社が 31 校、 $59.6 \%$ で最 も多く、ついで B 社が 13 校、 $25.0 \%$ あ゙あった。 補償内容は「学生が附属臨床施設で患者へ起こし た事故」が89.6\%で最も多く、ついで「教職員が 附属臨床施設で患者へ起こした事故」が66.7\%で あった。1校あたりの合計保険料は 1 万円以下か ら10万円以上とばらつきがあるが、5万円台が 18 校と最も多く、54,680円の学校が14校あった。 対人補償の限度額でも 1 千万円から 1 億円と幅が あり、1名について 3 千万円が 22 校、1事故につい て3千万円が 23 校で最も多かった。平成元年以降 の保険金の支払い事例は9校で13例あり、支払額 は最高で31万円、最低で11,620円であった。

【考察】臨床実習における賠償責任保険商品とし て流通しているのはA社の「鍼尒マッサージ臨床 実習賠償責任保険」だけであった。しかしす心゙て の学校でこの保険を契約しているわけではなく、 そのほかの保険商品はそれぞれの学校が代理店や 保険会社を通じて独自につくつたものであつた。 社会情勢の変化を鑑みて、各校が保険について再 認識し、再検討する必要もあると考える。

キーワード：あん摩鍼尒教育、臨床実習、実習中 の事故、賠償責任保険

\section{$1 \mathrm{P}-\mathrm{E}-15: 28$ 施炎技術の自動評価装置の開発}

東京衛生学園基礎医科学研究部

會澤重勝、勝又隆弘

【目的】施尒技術の評価は、竹筒や紙の上に施尒 し、手際のよさや、焼け焦げ具合から行ってきた。 時には、評価者の皮膚上に艾を立てさせたり、実 際に施众を行うことも行われている。皮膚上への 施众は最も臨床に近く望ましい事ではあるが、評 価者の負担が大きく、ばらつきも生じ易い。竹筒 や紙の上への施众では評価者の負担は軽減し、焼 け焦げの程度から施众時の温度の評価もある程度 客観的にできるが、多人数を評価する場合には作 業が煩雑で時間を要する。今回、センサー上に施 众を行い、これを自動的に評価する装置を開発し たので報告する。

【方法】スライドグラスに封入した熱電対を施众 部位とし、2つの施众部に交互に施众を行う。熱 電対の出力をソフトサーモを介してパソコンに接 続し、専用ソフトで温度デー夕を自動解析する。 評価は標準施众数、標準施众温度、上限温度、下限 温度、点火不良の判定温度を独立に設定して行う。 結果は施众のグラフに加えて、各壮ごとの施尒温 度の平均と標準偏差、施众間隔の平均と標準偏差、 下限温度と上限温度の間に収まる施尒数、上限温 度を超えた施尒数、下限温度に満たない施尒数、 点火不良回数、の值とコメントおよび評価点を表 示し、印刷する。

【結果】施尒の技術評価を自動的に行うことが可 能となつた。点火時の不手際は、従来の方法では 温度曲線を注意深く見なければ読み取れなかつた がこの装置により自動的に検出することが可能と なり、実技の評価に有用と考えられる。

【結語】従来は施尒時の温度曲線を記録計により 描き出し、この図から定規を用いて温度や、施尒 間隔を測定していた。これは大変煩雑で間違いも 起こりやすい。また、結果の通知にも時間を要し た。今回開発した方法では、施尒終了と同時に施 众温度曲線と各評価項目及び評価点が印刷される。 また、各被験者のデータが記憶されているのでク ラスの平均など統計も可能である。

キーワード：食、施尒温度、パソコン、評価、開 発 
1P-E-15: 42

\section{卒業試験におけるOSCE形式試験導入 の試み}

早稲田医療専門学校東洋医療鍼炎学科

鈴木盛夫、小岩信義、所 数樹、浅野貴之 坂本真紀、二本松明、町田雅秀

昭和大病院リハビリテーション科隹 武

【目的】近年銊尒師の養成施設において OSCE 客観的臨床能力試験の導入が進んでいる。本学で は平成 12 年度までの卒業認定実技試験は、学生 1 名に対し教員が 1 名で鍼炎実技及び取穴・理学検 査の成績判定を行っていたが、一部の学生から合 否の判定に不公平感があると批判があつた。そこ で平成13年度の卒業認定実技試験に OSCE 形式 を導入し、学生1名は 4 つステーション6分野を 巡り8人の教員に判定される方法で行った。学生 は共通の評価者に評価されることになつたが、そ れまでの実技試験とは違つた方法の試験を受験す ることになった。試験後に行ったアンケートの結 果を報告する。

【方法】対象は平成 13 年度の卒業認定実技試験 を受験した96名、内訳は昼間部学生68名（男40 名・女28名）夜間部学生28名（男15名・女13名）。 全員にアンケートを行った。

[結果] 問題の難易度は、「易しかった」が 14.6 \%、「普通だった」が $62.5 \% 、 「$ 難しかつた」が 22.6 \%。自分の結果をどう思っているかは、「出来た と思う」が37.5\%、「何ともいえない」が40.1\%、 「出来なかつた」が $21.7 \%$ 。実技能力の判定に意 義があると思うかについては $81.3 \%$ 学生が意義 があると答えた。この形式での卒業試験に賛成の 学生は $56.3 \%$ 、反対は $5.2 \%$ 、どちらとも言えな いが $37.5 \%$ でった。

【考察】受験生は卒業試験の約 1 ヶ月前に突然そ れまでに受けたことのない試験形式の要項を渡さ れ試験方法の説明を受けた。それにもかかわらず 前述のアンケート結果を得たことは、1.学生から 公平だと評価された、2. 臨床で役立つと評価さ れた、と言える。本学では未だ OSCE とは呼べ ず、ただ形式を採用したに過ぎないと考えている が、導入の途中経過としても、公平な試験である こと、認知領域の試験では計れない学生の情意領 域の技能を見ることができたことで、卒業認定実 技試験に導入したことは意義があったと言える。

キーワード：OSCE、卒業試験、評価
1P-E-16:00

盲学校における医療面接技法評価の 試み（第2報）

北海道高等盲学校

泉 重樹、岡部博之、舟崎 隆

【目的】第51回大会では本校において OSCEに よる医療面接評価を行い、視覚障害鍼尒・あ九摩 マッサージ指圧師養成施設においても OSCE 実 施は可能であり有用性は高いことを報告した。平 成14年度は臨床理療実習の中に医療面接カリキュ ラムとして OSCE を盛り込み、4月と11月にそれ ぞれ OSCEによる診断的評価と形成的評価を行 い、内容および評価について検討したので報告す る。

【方法】対象は本校専攻科 3 年生 10 名（理療科9 名・保健理療科1名）である。医療面接カリキュ ラムは OSCE を含め8時間で配当した。内訳は 4 月に医療面接事前指導 2 時間、第 1 回 OSCE 2 時 間、第1回 OSCE フィードバック 1 時間を行い、 11月に第2回 OSCE 2時間、第2回 OSCE フィー ドバック1時間の内容で行った。OSCE はステー ション(以下ST) を2つ設定し ST1で医療面接を 行い、ST2では医療面接内容を 4 択式で解答させ る筆記試験を行った。事前指導は態度としてよく ない例のモデル (教師が寒施)が医療面接している 場面をビデオで視聴しながら医療面接の態度・技 法について討議する方法で行い、フィードバック についてはビデオ撮影した各自の医療面接の模様 を生徒全員で視聴し意見交換しあう形式で行った。

【結果と考察】第1回 OSCE の結果、ST1のイン タビューのプロセス（患者への対応）の得点は $67( \pm 14.6)$ 点、インタビューのコンテント(症状 について)の得点は43.4 ( \pm 16.4$)$ 点、ST2の得点 は60(土27.4) 点であり、第2回 OSCE の結果はそ れぞれ、82.8（土14.8)、53.4( \pm 17.9$) 、 68.3( \pm$ 21.4）と1回目よりも2回目のほうが増加してい た。また今回は全盲教員による評価も実施した。 評価表の工夫と評価者の位置取りに配慮すること により全盲教員でも医療面接中の非言語的コミュ ニケーション評価の一部は可能と考えられる。

キーワード：医療面接、OSCE、臨床実習、評価、 視覚障害教育 
$1 \mathrm{P}-\mathrm{E}-16: 14$

鍼炎専門学校における臨床能力育成 の検討（第4報）

ーコミュニケーション技法の学習と指導一

明治東洋医学院専門学校

河井正隆

【目的】本校では、学生の臨床能力育成をテーマ に、授業「シミュレーション実習」を本年まで 9 年間継続し開講している。この授業から得られた いくつかの知見は、本学会で過去3回に亘り発表 を行つた。

そこで今回は、昨年の第51回大会（筑波大会） で発表した内容をさらに発展させ報告する。具体 的には、鍼众臨床における面接場面でのコミュニ ケーション技法の構造化を試み、面接に関する学 習上の着目すべきポイントや指導面での手だてを 抽出してみたい。

【方法】まずは、面接時のコミュニケーション技 法について、さまざまな文献を下敷きに整理・検 討し、その構造化（枠組みの作成）を行う。続い て、実際に学生が行った面接場面と突き合わせ、 学習と指導の両面から、コミュニケーション技法 の習得に有効な方法を検討する。

【結果と考察】得られたコミュニケーション技法 の構造をもとに、何点かの学習と指導の上で注目 すべき事柄が抽出された。以下に述べてみたい。 (1)面接の流れに影響を与えるコミュニケーション 技法として、質問方法の選別と傾聴のタイミング が挙げられる。(2)活用する質問方法により、“収 束的な面接”または “拡散的な面接”という2つ の流れが生じる。(4)積極技法の活用には、患者と の信頼関係のうえに用いてこそ、有用と思われる。 (5)コミュニケーション技法を階層構造として把握 することが、その技法の習得に有用と思われる。

【結語】鍼尒臨床における面接時のコミュニケー ション技法を習得するうえで、その技法の構造理 解にともなう適切な学習・指導が重要と思われる。

キーワード : 鍼尒臨床、医療面接、コミュニケー ション技法、臨床能力、

\section{$1 \mathrm{P}-\mathrm{E}-16: 28$ \\ 刺鍼技術実習の授業評価の試み}

明治鍼众大学臨床鍼尒医学 II 教室 明治鍼众大学健康鍼众医学教室 笹岡 知子 山田 伸之 明治鍼众大学臨床鍼众医学 I 教室 石崎 直人 明治鍼众大学臨床鍼尒医学血教室 佐々木和郎

【はじめに】刺鍼および施众の技術教育は、鍼尒 師を育成する上で非常に重要である。技術の習得 には、学生自身による自習復習が不可欠であり、 そのためにも学生と教員の相互の努力により学習 意欲を高く持たせ続ける事が必須である。同時に、 より良い教育を提供するためには、教育内容を自 己点検し評価を実施することが必要である。そこ で我々は、鍼技術学（演習）について授業評価を 目的としたアンケート調査を行ったので報告する。

【対象と方法】本学在学生 1 回生 118 名（男子 68 名,女子 50 名）を対象とし、全講義終了時に、多 摩大学および聖徳大学の授業評価アンケートの内 容を参考に授業評価アンケートを独自に作成した。 調査の内容は、大項目として1. 授業について (小項目；2項目）、2. 授業科目について（5項目）、 3. 授業に対する学生自身 (7項目)、4. 担当教員 （3項目）について調査し、回答は5段階の選択法 を用いた。それぞれの大項目において自由記述式 に意見を求めた。

【結果】アンケートの有効回答数は107であった (有効回答率 $91 \%$ )。授業に興味を持って参加し た 98 名 $(91.6 \%) 、$ 有意義な実習であった 85 名 (79.4\%) と高かったが、自習・復習を行った 62 名 (57.9\%)、質問を行つた58名 (54.2\%) と低 かった。自分の身体であれば不安なく刺鍼出来る 81名（75.7\%）であり、他人の身体に不安なく 刺鍼出来る 43 名 $(40.2 \%)$ であった。自由記述 式の意見で多かったのが、切皮痛を与えてしまう 事の不安感と、技術が臨床上どう活かされるのか という疑問や興味であった。

【結語】今回のアンケート調査により、学生の授 業に対する興味や参加意識は高いが、自習・復習 はあまり出来ていない事が明らかとなつた。本ア ンケート調査は、実習内容をより良く改善するた めの方法として有効で有り、今後、技術習得に対 する自己努力を促す工夫が更に必要であることが 明確になった。

キーワード：鍼尒、技術教育、授業評価、アンケー 卜調査 


\section{P-E-16: 42 \\ 鍼炎理論・臨床医学各論における授 業評価}

四国医療専門学校

桑野素子

明治鍼众大学健康鍼众医学教室

福田文彦

【目的】教育および教育効果を高めるためには、 適切な評価とそれに伴う教員および学生への双方 向のフィードバックシステムが必要である。授業 の受け手である学生の視点からの授業内容および 教育方法における問題点の抽出は貴重な評価とな る。そこで演者は、自身の授業における問題点の 抽出および授業内容向上を目的に授業についての アンケート調査を実施したので報告する。

【方法】対象は演者の担当授業（全3科目、鍼众 理論前半・鍼尒理論後半・臨床医学各論）を受け た本校学生とし、最終授業終了後に無記名、自記 式、集合調査法にて調査を行った。アンケートの 内容は I. 教員の授業の進め方に対する評価、II. 授業を受けた学生の自己評価とし、各項目とも5 段階の選択法とした。また、それと同時に授業に 対する意見を記述法により調査した。

【結果】アンケートの回収率は各科目において 86.5-95.3\%であった。各評価項目の「非常にそ う思う」と「そう思う」の割合は以下のようになつ た。Iでは「熱心であった」(78.3-93.9\%)、「準 備は十分であった」(65.0-100\%)、「解説はわか りやすかった」(53.0-77.0\%)、「回答は適切だっ た」(53.0-77.0\%)、「板書は見やすかった」 (46.2-86.4\%) などであった。II では「積極的な

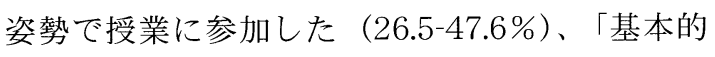
事項が身についた」（23.1-41.5\%）などとなつた。

【考察および結語】Iでは大半の項目で「非常に そう思う」「そう思う」の割合が5割以上という 評価が得られたが、IIではいずれの項目も5割に 満たなかつた。教員自身がより深い知識を持った 上で授業に臨み、学生の疑問点に的確に回答でき るようにすることが授業内容の向上や学生の興味・ 関心を惹くことにつながると思われる。そして、 それが学生の学習に対する積極性の向上を可能に させると考える。

キーワード：授業評価、アンケート調査、学生の 積極性

\section{0-B-09:00 \\ 足臨泣の施鍼による頸部圧痛の変化}

南雲治療院・北海道地方会

南雲三枝子

【目的】足臨泣に施鍼し、頸部（完骨付近）の最 大圧痛点の圧痛の変化を、鍼経験群と未経験群と に分けて検討した。更に、圧刺激による痛みの感 受性と自己評価の差異について考察を試みた。

【方法】頝部の痛み・重苦しさ・こわばり感等の 愁訴をもつた100例 (男41例・女59例、年齢19〜 83 ・平均 47 歳）を対象に、仰臥にて安静を得た 後、40ミリ16号鍼を用いて左右足臨泣に5分間の置 鍼を行った。計測は、左右完骨付近の最大圧痛点 に対し、圧痛計（FPメーター）を用いて施鍼前 後の圧痛閾值の変化をみた。VASは、施鍼前の 圧痛閾值の痛みと抜鍼後、施鍼前の圧痛閾值の数 值にて加圧した痛みの程度を表現させた。経験群 は66例（男25例・女41例）、未経験群は34例 （男16例・女18例）である。

【結果】100症例の圧痛閾值は上昇（ $\mathrm{p}<0.01 ） 、$ $\operatorname{VAS}$ は低下 $(\mathrm{p}<0.01)$ 。経験群の圧痛閾値は上昇 ( $\mathrm{p}<0.01) 、 V A S$ は低下 $(\mathrm{p}<0.01)$ 。未経験群の 圧痛閾值は変化が認められず、VAS は低下（p< 0.05 )。

【考察】今回、経験群は圧痛閾值とVAS共に改 善をみた。過去に鍼治療により愁訴の軽減を得て いる経験群は、施鍼により望ましい生体反応が生 じ圧刺激による痛みに対して良好な感受性を示し たものと推察する。術者は、より快適で満足感が 得られる治療を提供することが、鍼効果を高める 上で大切であると考える。未経験群は術後、客観 的な圧痛閾值に変化がみられず主観的なVASに 改善をみたことより、鍼効果に対する期待や要求 等の心理的要因及び、銊治療の紹介者やマスコミ 等から得ていた情報や学習による予備知識等が VAS に影響を及ぼしたものと推察する。痛みの 感受性は個人差が大きくしかも、不安や緊張等の ストレスがある未経験群は感受性が高いと考えら れることより、リラクゼーションの必要性やコミュ ニケーションの重要性が伺われた。

キーワード：足臨泣、頸部圧痛、圧痛閾値、VAS、 銊経験の有無 
20-B-09: 12

急性頚部痛に対する鍼治療効果につ いて

\author{
一刺鍼群と偽銊群の比較（第2報）-
}

古東整形外科

小澤庸宏、古東司朗

【目的】第50回本学会において当院の田辺らが 急性頚部痛に対する銊治療の効果について報告し た。今回我々は、さらに症例を追加し、ランダム 化比較臨床試験（以下RCT）をもちいて鍼治療 効果の検討を行なつた。

【方法】対象は2000年9月から2001年2月までに 急性頚部痛を主訴として来院した 30 症例（男性 10 例、女性 20 例、平均年齢52.6歳) を対象とし た。全例インフォームドコンセントを行ない同意 が得られた後、封筒法にて刺鍼群と偽鍼群に割付 を行なった。刺鍼群の治療法は、患者を伏臥位と 乙両側の風池、肩井と頝部最大圧痛部一点の計 5 穴に $50 \mathrm{~mm} 20$ 号鍼を刺入したの後、置鍼を 10 分間 行なった。偽鍼群は、前述の5穴に銊管だけを吒 打した後、伏臥位姿勢を10分間行なわせた。評 価方法は治療前後の頚部運動時痛についてVAS をもちいて評価した。

【結果】刺鍼群のVASは治療前 $67.2 \pm 17.8$ 、治 療後50.0土19.4で有意差が認められた $(\mathrm{P}<0.01)$ 。 偽銊群のVASは治療前 $73.9 \pm 16.1$ 、治療後 $59.9 \pm$ 22.0 で有意差が認められた $(\mathrm{P}<0.05)$ 。また治 療後のVASについては両群間に有意差は認めな かった。

【考察】当院の田辺らは、神経根症状を認めない 急性頚部痛に対して鍼治療を行ない、両群共に治 療前後のVASは有意に減少していたと報告した。 今回の結果も前回の報告と同様に、治療前後にお けるVASは有意に減少していた。よって、急性 頚部痛に対して鍼治療が有効であるが、その効果 には鍼の効果に加え、プラセボの関与も考えられ た。また、銊経験の違いや、原因疾患による違い が効果に影響したものと考えられた。

【結語】急性䅡部痛に対して銊治療が効果的であ るが、プラセボの関与も考えられる。

キーワード：急性頝部痛、偽鍼、プラセボ効果、 銊治療

\section{0-B-09:24}

胸郭出口症候群に対する鍼治療（第5

報）

ールーステストにおける上肢末梢循環動態の検討一

東京大学医学部附属病院リハビリテーション部 小糸康治、美根大介、粕谷大智、杉田正道 江藤文夫

【目的】我々は本学会において、胸郭出口症候群 (以下TOS)の評価に用いられているルーステス 卜についてサーモグラフィにより手指皮膚温変化 を観察・分類し、胸郭出口部での神経刺激症状の程 度と罹病期間が関与する可能性を示した。また鍼 施術での症状緩和に伴いサーモグラムのパターン も変化し神経刺激症状の改善が認められた。そこ で今回我々はサーモグラフィとレーザードプラー 血流計を用い胸郭出口部への鍼施術が上肢末梢循 環動態に及ぼす影響について検討したので報告す る。

【方法】対象は安静時上肢症状を自覚しないが脈 管テストで症状誘発される6名。鍼施術は中斜角 筋に対し低周波鍼通電を10分間行った。サーモ グラフィの測定方法は鍼施術の前後、一定の室温 下で座位にて肘の高さの台に上肢を置き、皮膚温 安定後ルーステストを行い、上肢を元の位置へ戻 した後、経過を12分間観察した。測定部位は両 側第1〜5指の爪根部とした。またレーザードプ ラー血流計により両側中指指先部の血流量を測定 した。

【結果】 鍼施術前は全例でサーモグラムに回復の 遅延など健常者と異なるパターンが認められた。

鍼施術後、脈管テストでの陽性所見や上肢症状誘 発に臨床上有意な変化は認められなかつたが、上 肢挙上負荷中の血流量は鍼施術前より増加し、負 荷直後の皮膚温低下も軽減した。また皮膚温回復 の時間も短縮しサーモグラムのパターンに改善が 認められた。

【考察と結語】鍼施術後、挙上負荷中の手指血流 量が増加したことから、胸郭出口部の緊張緩和に よる阻血状態の改善、もしくは挙上に伴う腕神経 叢に対する刺激の軽減の可能性が示唆された。ま た上肢皮膚温の回復時間短縮から交感神経機能六 進状態の軽減が示唆された。以上サーモグラフィ とレーザードプラー血流計より TOS の病態を把 握でき、鍼治療経過の客観的評価に有用と考えら れ、TOS症例に対する鍼治療の有用性が期待さ れた。

キーワード：胸郭出口症候群、ルーステスト、鍼 治療、サーモグラフィ、レーザード プラー血流計 
20-B-09:36

\section{肩関節周囲炎に対する鍼治療(第5報)}

一拘縮症例についての治療効果一
東京大学医学部附属病院リハビリテーション部

美根大介、小糸康治、粕谷大智、杉田正道 江藤文夫

【目的】我々は本学会において、拘縮を伴う症例 は非拘縮例と比べ治療効果が劣り、治療に長期を 必要とすることを報告した。一般的に拘縮を伴う 患者は医療機関においても治療手段は少なく、症 状の軽減を期待し鍼炎治療を受ける場合が多いと 思われる。そこで今回、拘縮を伴う症例の銊众治 療に対する満足度及び満足度に影響を与える要因 について非拘縮群を対照として検討したので報告 する。

【方法】対象は当院において肩関節周囲炎と診断 され鍼治療を行った11例 12 肩（男性5例、女性6 例、平均年齢62.7歳）である。これを拘縮群5肩、 非拘縮群7肩に分類し 2 群間を比較した。評価項 目は(1)疼痛の程度、(2)関節可動域、(3)日常生活動 作、(4)銊尒治療全般に対する調査とした。

【結果】銊治療により全例で疼痛の軽減、可動域 の改善、日常生活動作の向上が認められたものの、 拘縮群では非拘縮群と比べ改善しにくい傾向であつ た。しかし、満足度はVAS (visual analogue scale）において両群ともほぼ同様であり、その 内容については拘縮群で肩の動かしやすさ、だる さの軽減などの治療効果や、施術者の説明、日常 生活上のアドバイスなどの施術者に対する評価が 多くみられた。

【考察と結語】今回の結果は従来報告されている ように、拘縮群では疼痛の軽減や可動域の改善が 非拘縮群と比べ劣る傾向であった。しかし、鍼治 療に対する満足度は高く非拘縮群と比較しても同 様であった。これは拘縮を伴う症例の場合、疾病 治癒を期待したものではなく、上述した治療効果 や日常生活指導など QOL の向上を期待しており、 銊治療はその期待に応えたことで満足度を高めた ものと考える。

キーワード : 鍼治療、肩関節周囲炎、拘縮

\section{0-B-09:48 \\ 可動域テストによる関節構成要素の 形態学的変化亡施術への応用}

一肩関節に有用性が認められた 1 例一

国立身体障害者リハビリテーションセンター

舘田 美保

防衛医大 - 解剖第 1

日本柔整鍼尒専門学校

竹内 京子

埼玉東洋医療専門学校 小比賀黎子 一の瀬 宏

【目的】運動器疾患における評価で、関節可動域 (ROM) テストは一般的に角度計測を行うもので ある。我々は、このテストを施術の一部という前 提で施術を行っている。評価は、ROMに加え工 コー像により軟部組織の状態観察をしている。今 回は、複数の慢性外傷を有するラグビ一選手に、

この方法で施術を行い有用性が認められたので報 告する。

【症例】22歳男子（医学科学生、ラグビ一部）

主訴: 左右肩の挙上制限、不安定感と疼痛。既 往歴: 平成 13 年 4 月 右肩関節覀脱臼、平成 13 年 10月 右鎖骨骨折。その他、肉離れ、膝関節捻 挫、手指の突き指等、競技の特性から頻回に受傷 をしている。

【方法】左右肩関節を対象に ROM テスト（自動、 他動）を行った。ROM テストは施術の前後に、 屈曲位・外転位にて行つた。なお、他動テストに ついては、Scaption で挙上に抵抗感のない方向 をさぐりながら、90 挙上までは肩峰を固定し ながら行つた。他動 ROM テス卜効果を検討する ため、自動 ROM テストを 1 回のみ実施し、食施 術した。また、エコーにて、すべての検査、もし くは施術の前後に患部を観察した。

【結果】自動ROMテストとそれに続く他動 ROM テスト直後の可動域は左右とも約 10 度改善して いた。しかし、患側と健側間の差は10度のまま であった。食施術後は、健側には変化が認められ なかったが、患側は10度改善し、両者間の差は 消失した。

【考察と結語】肩可動域制限の著しいスポーツ選 手において、他動による肩関節 ROM テストその ものが、施術としての効果があると考えられてい るが、テスト後の众施術は、慢性外傷に伴う痛み、 筋力低下等の症状の改善が認めた。エコー観察を 行いながらのテストならびに施術は被検者に対す るインフォームドコンセント得るのに非常に有用 であった。

キーワード：スポーツ銊众、众療法、関節可動域 テスト、Scaption、関節構成要素 
20-B-10:00

\section{腰痛に対する鍼治療の検討（2）}

ーJ0AスコアとVAS、FFDを使用した多施設での症 例集積結果一

愛知地方会研究部疼痛疾患班

堀茂、河瀬美之、石神龍代、中村弘典 服部輝男、皆川宗徳 甲田久士、井島晴彦 中村高行、絹田 章、校條由紀、黒野保三

【目的】鍼众院を訪れる患者のうち、疼痛疾患で も特に多い腰痛に対する銊治療の有効性を客観的 に検討する目的で、鍼治療の有効性を定量的に見 出すスケールを用い、班員による多施設での症例 集積を行って医学統計処理を行つた結果、興味あ る結果が得られたので報告する。

【方法】平成 12 年 5 月より平成 14 年 11 月までの 間に 12 施設に来院した患者のうち、主訴が腰痛 であった患者134例（平均年齢52.9歳,男 : 女二 81:53）に対し鍼治療を行った。その評価とし て日本整形外科学会腰痛疾患治療成績判定基準 (JOAスコア) と Visual Analogue Scale (VAS)、 前屈指床間距離（FFD）を使用してそれぞれの 推移を観察し、腰痛に対する鍼治療の有効性を検 討した。統計処理はJOAスコアに対しては Mann-Whitney U test、VASに対しては Wilcoxon rank sum test、FFDに対しては不 合順位検定を用いた。

【結果】初診時と平均治療回数 3.4 回の最終時を 比較すると、JOA スコアは平均18.6点が23.0点、 VAS は10〜100が0〜 100、FFD は平均 $22.6 \mathrm{~cm}$ が $15.7 \mathrm{~cm}$ となり、それぞれ有意な改善 $(\mathrm{p}<0.05)$ が認められた。また、最終時の効果判定は著効 27 例 $(20.1 \%)$ 、有効 42 例 $(31.3 \%)$ 、やや有効 48例 $(35.8 \%)$ 、無効17例 $(12.7 \%)$ となり、症 例の $87.3 \%$ に何らかの改善が認められた。

【考察と結語】今回の結果は、腰痛に対する鍼治 療の有効性を示唆するものと思われ、今回のよう なスケールを用いることは鍼治療の有効性をより 客観的に検討することができる一方法と思われる。

キーワード : 腰痛、JOAスコア、VAS、FFD

\section{0-B-10: 12}

\section{慢性腰痛患者に対するトリガーポイ ント鍼治療の試み}

明治鍼尒大学臨床銊尒医学 II 教室

伊藤和憲、越智秀樹、北小路博司

明治鍼尒大学整形外科教室

小嶋晃義、北條達也、勝見泰和

【目的】慢性腰痛に対して鍼治療は効果的な保存 療法と考えられているが、その治療方法は様々で あり治療成績も異なる。一方、慢性腰痛の原因の 一部に筋・筋膜由来の疼痛が関与していることか ら、筋・筋膜に対する治療の必要性が報告されて いる。そこで慢性腰痛患者を対象に、腰下肢痛に 効果があるとされる経穴への治療群（経穴群）と 筋・筋膜への治療群（トリガーポイント治療群 : $\operatorname{TrP}$ 群）の2群に分け、鍼治療の効果を検討した。

【方法】明治鍼众大学附属病院整形外科を受診し、 6ヶ月以上腰下肢痛が持続している患者の中で、 インフォームドコンセントの得られた8名（68.9 土6.4歳）を対象とした。患者は封筒法により無 作為に経穴群と TrP 群の2群に分け、それぞれ週 1 回で計 3 回の治療を行つた。効果判定は施術前 に腰下肢の痛みを VAS $(100 \mathrm{~mm})$ 、治療開始時 と治療 3 回終了時に QOL を Roland Morris Questionnaire (RMQ：24点満点）にて評価し た。

【結果】対象患者は全例退行性変化を基盤とした 変形性腰椎症であった。治療前経穴群ではVAS: $54.0 \pm 19.2 \mathrm{~mm} 、 \mathrm{RMQ}: 7.2 \pm 2.0$ 点、 $\operatorname{TrP}$ 群では VAS : $54.3 \pm 24.6 \mathrm{~mm}$ (mean \pm S.D.) 、 RMQ : $12.2 \pm 3.5$ 点であったのに対し、治療 3 回終了後 経穴群ではVAS: 50.0 \pm 10.5mm、RMQ: $7.7 \pm$ 2.1 点、TrP 群ではVAS : $28.0 \pm 16.6 \mathrm{~mm} 、 \mathrm{RMQ}$ ： $3.3 \pm 2.3$ 点でTrP群に著明な改善が見られた。

【考察・結語】銊众治療は慢性腰痛に対して効果 的な保存療法の一つである。今回腰下肢痛の原因 となる筋肉に対してトリガーポイント治療を行う ことにより、高い治療効果を得ることができた。 このことから、慢性腰痛患者に対して鍼治療を行 う際には、筋・筋膜由来の疼痛を考慮した治療法 (トリガーポイント治療) が必要であると考えら れた。

キーワード : 慢性腰痛、QOL、トリガーポイン 卜治療 
20-B-10:24

\section{アトピー性皮膚炎を有する椎間板へ ルニアに対する鍼炎治療の 1 症例}

埼玉東洋医療専門学校・東京地方会一の瀬宏 日本柔整鍼尒専門学校 土肥康子、小比賀黎子 防衛医大解剖第一講座竹内京子

【目的】前回まで肩こり症状に数穴の皮膚接触鍼 法（鍉銊）が症状改善の自覚的変化をもたらし、 並びに主要経穴部のエコー像の変化を観察してき た。今回椎間板ヘルニアによる下肢疼痛としびれ に対して鍉鍼を試み症状と罹患していたアトピー 性皮膚炎の改善が見られた一症例を報告する。

【症例】36歳男性 医師 (救急救命外科医) 身 長 $178 \mathrm{~cm}$ 、体重 $86 \mathrm{~kg}$

主訴：右大腿前・外側の疼痛としびれ。両足のし びれ。

現病歴：平成6年入浴後ギックリ腰、以来長時間 の手術後に痛み、及びしびれが出現。1年前に MRI撮影によりTh12・L1、L4・5の椎間板へ ルニアを確認。日常的には問題箇所を探りなが ら台座尒の試行、運動療法により疼痛の改善を 図っていたが、激務のため最近は両足がしびれ るようになり、自助努力だけでは症状緩和の効 果を保てなくなった。

治療：銀製鍉鍼（直径 $0.3 \mathrm{~mm}$ 長さ $80 \mathrm{~mm}$ ）にて

(手当ての鍼と命名) と知熱众（燃焼温度34 $\left.36.6^{\circ} \mathrm{C}\right)$ を行う。1回目（02年 $11 / 20 ）$ 下脘穴 知熱众 3 壮、鳩尾・右太白 ・ th 12 - 腰の陽関に 皮膚接触鍼法。2回目 $(11 / 27)$ 下脘穴・関元 知熱食 3 壮、th $3 \cdot 9 \cdot 12$ - 右中封 - 曲泉 - 左陽 稜泉・三里に鍉鍼。3回目 (12/4) 以後継続の 治療を行う。術前後に姿勢・動作チェック並び にエコー像による軟部組織経穴部の観察を行つ た。他に皮膚表面の写真を撮つた。

【結果】治療初期の頃にはしびれは著効で2日間、 疼痛は7日間位緩解するが、後は緩慢に薄皮を剥 がすように改善していった。経穴部のエコー像の 変化が認められた。腰痛が軽減するとアトピ一症 状も変わつた。

【考察・結語】本症例の改善に鍉鍼治療が役にたつ たと思われる。

キーワード：皮膚接触鍼法、鍉鍼

\section{0-B-10:36 \\ 脊椎圧迫骨折に対する銊治療}

清野鍼尒整骨院・東京地方会

今田開久、清野充典

【目的】当院では1988年2月に鍼众・整骨院とし て開院以来、様々な外傷に対する鍼众治療を試み てきた。今回我々は、当院で取り扱つた脊椎圧迫 骨折患者の訴える腰部〜背部痛に対する鍼治療の 効果を検討したので報告する。

【対象と方法】対象は、腰背部痛を主訴とし来院 した患者群で、他医療機関において脊椎圧迫骨折 と診断、または臨床所見により圧迫骨折の疑いの 高い患者群10例 (男性3例・女性7例)、年齢56 77歳（平均年齢70.1歳 \pm 6.9 歳、mean $\pm \mathrm{SD}$ ) で あり、発症からの期間は、1 92日（平均41.6日 土30.9日）である。施術方法は、圧迫骨折部上下 の左右棘間傍点に対し、ステンレス鍼 $40 \mathrm{~mm} 16$ 号鍼を用い管鍼法で弾入切皮し、刺鍼深度は皮下 に到達しない程度までとし10分間の置鍼術を行つ た。評価方法は患者の自覚症状を指標とした。尚、 銊施術後骨折部位はサラシ、またはコルセットに て固定し経過を観察した。

【結果】患者群の急性期疼痛は、いずれの症例も 鍼治療直後より緩解し、放射状に広がる腰背部痛 は4〜5回の鍼治療により消失した。また、慢性 期に残る背部痛についても同様の効果が見られた。

【考察】通常、骨折による疼痛は固定が十分であ れば最小限に抑えられるが、春椎骨折では固定が 困難であり体位変換等、疼痛を生じる要素が数多 く、また骨折部を中心に腰背部に放散痛・自発痛 を伴う事も多い。脊椎圧迫骨折に伴う疼痛は、骨 膜・椎間関節部、及び脊椎周囲の軟部組織由来の 疼痛であることが考えられるが、受傷からの経過 期間や銊刺入深度により銊治療効果に差があるこ とも考えられた。

【結語】脊椎圧迫骨折に伴う疼痛に対し鍼治療を 行ない、症状の緩解を得ることが出来た。これら の事から、骨由来の疼痛に対する鍼鎮痛機構に影 響があった事が考えられ、他疾患に対する臨床応 用も可能であることが示唆された。

キーワード : 春椎圧迫骨折、外傷、刺鍼深度、鍼 治療 
20-B-10:48

環跳穴低周波鍼通電療法施術前後の 血中セロトニン值の変動

福岡地方会

大淵千尋、箱嶌大昭

【目的】セロトニン (5-HT) は坐骨神経痛では減 少し、鍼治療後は増加するとされているので、環 跳穴低周波鍼通電前、後の変動を正常人 1 名、坐 骨神経痛患者 1 名で術前術後に測定検討した。

【方法】対象は正常人 1 名、患者 1 名の計 2 名であっ た。術式は環跳穴に刺銊し $(-)$ 、更に秩辺穴に刺 鍼 $(+)$ して低周波鍼通電を $1 \mathrm{~Hz}$ 15分間行い、術 前、術後に採血した。採血した検体は（株）シー・ アール・シーに 5-HT 測定を依頼した。鍼は（株） タガシン製 $90 \mathrm{~mm} 20$ 号針、低周波通電器は全医 療器製オームパルサーLFP4500であった。

\section{【結果と考察】}

鍼通電前の血中 $5-\mathrm{HT}$ 濃度は正常人で 305.0 ng/ml であったが、坐骨神経痛患者では低下し ている傾向にあり $79.7 \mathrm{ng} / \mathrm{ml}$ であった。また、 鍼通電に伴い正常人では $272.0 \mathrm{ng} / \mathrm{ml}$ 、坐骨神経 痛患者では $74.5 \mathrm{ng} / \mathrm{ml}$ へといずれも低下する傾 向にあった。

【結語】坐骨神経痛に対し環跳穴低周波通電療法 は、その症状の緩解作用にセロトニン増加が関与 していると推察される。
20-B-14:00

超音波断層法による筋硬結の検討 （第3報）

日本臨床鍼尒愁話会 ${ }^{11}$ 、川村病院神経内科 ${ }^{2)}$

星野良和 ${ }^{1)}$ 、湯谷 達 ${ }^{1)}$ 、鈴木 信 ${ }^{11}$ 竹田博文 ${ }^{1)}$ 、尾崎朋文 ${ }^{1)}$ 、米山 榮 ${ }^{1,2)}$

【目的】我々は腰部において高率に筋硬結が認め られ、鍼众臨床においても治療点として頻度の高 い志室穴周囲の筋硬結について、エコー・C Tを 用いて検討してきた。そして志室穴周囲において その深部には肋骨突起が存在し、筋硬結を触れる 例の過半数に肋骨突起近傍に高輝度像を認めるこ とを報告した。今回䅡肩腕痛・肩こりにおいて、 筋硬結が高率に認められ治療点としても重要と思 われる肩外俞・肩井穴のエコーによる検討を行っ たので報告する。

【方法】川村病院神経内科を受診した肩こりを訴 える患者8名 (女性8名、年齢27～74歳) の肩外俞・ 肩井穴、左右各16部位を対象に、触診による筋 硬結の理学的所見・エコーによる検討を行った。

\section{【結果】}

\section{(1)触診所見}

肩外俞穴 : 1度 (筋緊張様) 1部位。2度（弾力 ある硬結）15部位。

肩井穴 : 1度 (筋緊張様) 10部位。2度（弾力 (2)エコー所見 ある硬結）1部位。硬結なし 5 部位。

肩外俞穴：線状高輝度像：14部位。

肩井穴：線状高輝度像：13部位。

【考察】肩外俞穴の近傍には肩甲骨内上角、肩井 穴の深部には肩甲骨内上角・第1肋骨が認められ、 それぞれ骨周囲に高輝度像が認められた。これは 肩甲挙筋など僧帽筋の深部に存在する筋の高輝度 像と思われ、特に肩外俞穴においては肩甲挙筋の 停止部が筋硬結に関与する可能性が示唆された。 また肩井穴においては僧帽筋内に高輝度像が認め られる例もあり、筋腹においては筋硬結に筋膜が 関与している可能性が示唆された。

キーワード：筋硬結、起始停止部、筋膜
キーワード：坐骨神経痛、低周波鍼通電療法、セ ロトニン (5-HT) 
20-B-14: 12

\section{腰痛自覚者腰部における硬さの左右 差の成因について}

一皮下組織の厚さとの関連一

明治東洋医学院専門学校 有馬義貴、高野道代

【目的】腰痛自覚者の腰部では脊柱を挟んだ左右 で硬さに差があることがこれまでの研究で明らか になっている。また、皮下組織の厚さが硬さ決定 の大きな要因であることも明らかになっている。

このことから、腰痛自覚者における硬さの左右差 は皮下組織の厚さが変化したことによって起こっ ている可能性が考えられる。そこで、腰痛自覚者 における腰部の硬さと皮下組織の厚さについて測 定し、腰痛自覚者腰部における硬さの左右差の成 因に皮下組織の厚さが関与するかについて検討を 行つた。

【方法】健康成人ボランティア（腰痛非自覚者 1 2名、腰痛自覚者12名）の腰部の硬さおよび皮膚 表面から筋膜までの皮下組織の厚さを生体用組織 硬度計および超音波診断装置を用い多点的に測定 した。なお腰痛の自覚以外に明瞭な差がない者の 腰部を対象とした。

【結果】腰痛自覚者群では脊柱を挟んだ腰部の硬 さに有意な左右差が認められた。しかし、皮下組 織の厚さに有意な左右差は認められなかつた。

【考察と結語】皮下組織の厚さが皮膚表面から触 知する硬さの主要な成因であるが、腰痛自覚者腰 部における硬さの左右差の成因についてはその他 の要因を検討する必要があることが明らかになっ た。

\section{0-B-14:24 \\ 肩凝りの鍼治療が精神的ストレス認 知に与える影響について}

兵庫鍼众専門学院

梶間育郎

【緒言】鍼众臨床において肩凝り症は臨床上よく 見られる症状であるが、一般にその原因は単に局 所筋群の疲労のみならず、他の身体症状との関連 や精神的なストレスとの関連が示唆されている。 本研究では、肩凝りとして自覚される愁訴の改善 によって、その他の身体的、精神的愁訴の改善に ぞの様な影響が見られるかについて臨床的検討を 試みた。

【方法】肩凝りを自覚し、CMI による調査で精 神的愁訴の是認回答数の比較的多い 24 歳から 42 歳の成人男女（女12名、男7名、平均年齢 $32.7 \pm$ 5.5歳）を被験者群とし、天柱、肩外俞、肩井、

肺俞、膈俞の左右 10 穴に対し、セイリン社製 50 $\mathrm{mm} 、 20$ 号ステンレス鍼を用い、得気を得た後 10 分間の置鍼を行う方法で週 1 回、3週間にわた り3回の治療を行った。局凝りの自覚状況は各回 治療の前後に被験者自身によりVASに記入させ た。全身愁訴及び精神愁訴の状況は初回治療前と 終了時に CMI を用いて調査し、それぞれの改善 変化を統計手法を用いて検討した。

【結果】各被験者の VAS による肩凝り自覚の改 善率とCMI による身体愁訴、精神愁訴全項目合 計の各是認回答率増減において、スピアマン順位 相関係数は、身体愁訴 0.31 、精神愁訴 0.44 、全項 目合計 0.48 であった。また減少した人数の多い項 目は、「目と耳」「消化器系」「筋肉骨格系」「疲労 度」「怒り」などであった。

【考察と結語】肩凝り局所に対する鍼治療は、そ の部位の筋の緊張を緩和するだけではなく、精神 的緊張などのストレス反応についても緩和する傾 向があり、それらの改善は心身の緊張に関連する 消化器系や目の疲労等の症状改善にも影響すると 思われる。よって、肩凝りの鍼治療は、単に局所 的治療というだけでなく、心身相関として全人的 な健康管理面においても有用であると考えられる。 キーワード：肩凝り、精神的ストレス、鍼治療 


\section{0-B-14:36 \\ 遠位経穴刺激の基礎的研究（第6報）}

一腰痛治療点としての「承山一飛陽－崑崙」の刺 鍼刺激効果の検討一

日本鍼尒理療専門学校 ${ }^{1)}$

(財) 東洋医学研究所 ${ }^{21}$

大場雄二 ${ }^{1,2)}$ 、筒井宏史 ${ }^{1,2)}$ 、白石武昌 ${ }^{2)}$

【目的】前回、軽一中等度の腰痛患者に対して、 足太陽膀胱経上の「承山、「飛陽」、「崑崙」刺激 に通電刺激を行い、腎俞における閾值の変化、す なわち、応答性の変化等を報告して来た。今回は その腎俞の応答性を「承山、「飛陽」、「崑崙」へ の刺鍼刺激により、測定することにし、興味ある 成績が得られたので、その一部を報告する。

【方法】実験は、インフォームドコンセントを得 た健康成人男（17名）、女（15名）と、「腰痛患 者」男（12名）、女（27名）を被験者とした。応 答性の測定部位は、左右足の太陽膀胱経の腎俞と した。測定方法は、測定部位にSSP電極およびシー ルを貼付の後、測定した。測定条件は、従来の成 績を参考に、電気刺激装置よりパルス幅 $0.02 \mathrm{~ms}$ 、 矩形波による単一刺激電圧 $48.5 \mathrm{~V} \sim 168.9 \mathrm{~V}$ で行つ た。 測定時間は、刺鍼前10分、それぞれの経 穴への刺鍼直後、10分経過・抜鍼直後、抜鍼 10 分後、抜鍼 20 分後、抜鍼 30 分後、抜鍼 40 分後に 測定した。刺鍼方法は、安静伏臥位で、鍼は、40 $\mathrm{mm} 、 18$ 号で約 $15 \mathrm{~mm}$ 刺入後雀豚をし、得気を 得た後、置鍼した。

【結果・考察】先の委中鍼刺激の劇的な閾値の上 昇（治療効果）や、前回の通電効果に比し、更に 遠位での「刺鍼」の役割は多様で、「承山」への 刺鍼により、患者群は男女とも腎俞での応答性は 上昇、また女性の健常群も腎俞の応答性を上げた ( $\mathrm{p}<0.05)$ 。女性の「諧崙」では腰痛の有無に拘ら ず明らか（ $p=0.02-0.03 ） に そ の$ 店答性を高めた。 一方、「飛陽」での変化は「健常群」で応答性は 経時的に動摇があるものの低下傾向が認められた。

【結語】同一経絡上の経穴では「委中〜承山、飛陽、 崑崙」とその解剖学的位置とは直接関係しない、 それぞれ固有の経穴特性があることを確認した。

キーワード : 遠位経穴刺激、腰痛、腎俞-委中 • 承山・飛陽・崑崙
20-B-14:48

脛骨叨打テストの有用性について

一脛骨内側顆骨壊死症之変形性膝関節症との比較一

明治銊尒大学臨床鍼尒医学 II 教室

越智秀樹、伊藤和憲、北小路博司

明治鍼众大学整形外科学教室

勝見泰和、北條達也、小嶋晃義

【目的】膝関節特発性骨壊死が一つの疾患として 報告されて以来、二次性の変形性膝関節症の原因 の一つとして注目されるようになつた。鍼尒臨床 においても脛骨内側顆骨壊死症と変型性膝関節症 の鑑別が不明瞭であり困難を伴う。そこで今回本 疾を銊尒師の立場で分析しうる方法として新しく 考案した検査法を施行し検討を行なつたので報告 する。

【対象・方法】対象は、本学附属病院整形外科戈 よび附属鍼尒センターに膝痛を主訴とし受診し、 四肢専用 MRI (ARTOSCAN, ESAOTE BioMedica 社製）で脛骨内側顆部に骨壊死様所見が 確認された患者5名（骨壊死群）と、変形性膝関 節症をX-pにて分類した、初期例8名（初期OA群）、 中期例 8名 (中期 OA 群)、末期例 8名 (末期 OA 群）を対象とした。これらの症例に脛骨粗面部を 吒打し、健側と患側のひびき感覚の違いを確認す る脛骨叮打テストを施行した。また臨床所見とし て発症状況、発症の誘因の有無、発症時の疼痛の 程度を4段階で評価した。

【結果】脛骨叨打テストの結果、骨壊死群はすべ ての症例で健側と患側との吒打による左右差が確 認でき陽性であった。また変形性膝関節症の初期 OA 群はすべてにおいて陰性であり、中期 $\mathrm{OA}$ 群 は1名のみ擬陽性以外はすべて陰性であった。し かし末期 OA 群は2名が陽性、2名が擬陽性、4名 が陰性となった。

【考察・結語】骨壊死の病巣は、微少骨折が発生 しその結果形成されるという説がある。今回我々 が行なつた脛骨吒打テストは、吒打により、骨伝 導で微少骨折を来している壊死病巣部へ刺激が伝 わり、陽性所見が確認出来たと考えれれる。また 変形性膝関節症の末期例 2 症例で陽性が確認され た理由として、これらの症例は関節軟骨の破壊が 進行し骨組織へ及ぼし出現したと考えられる。末 期 OA を除外すれば、脛骨吒打テストは本疾患 の病態把握に有用な一方法であると考えられた。

キーワード : 脛骨内側顆骨壊死症、骨壊死、変形 性膝関節症、脛骨吒打テスト 


\section{0-B-15:00 \\ 高知国体セーリング競技会場でのコ ンディショニング効果}

東京医療専門学校

古屋英治、小川裕雄、石川慎太郎 金子泰久、坂本 歩

【はじめに】第57回国民体育大会夏季大会セ一 リング競技選手に対するコンディショニング効果 を調査したので報告する。

【方法】高知県夜須町セーリング会場に平成 14 年9月21～23日、9:00～17:00（最終日 14:00迄） にコンディショニングルームを開設した。利用者 は年齢、性別、種目、競技歴、主訴等必要事項を各自 で記入した。コンディショニングは鍼治療が主で 取穴は主訴の局所とし、単刺術・置鍼術及び散鍼を 用いた。その他必要に応じてアイシング・テーピ ング・ストレッチ・マッサージ（以下他手技）を 用いた。効果の判定は主訴に対する施術前後の visual analogue scale (VAS) 值を求め、有意 差の検定は $\mathrm{t}$ 検定で行った。

【結果】利用者は延へ人数 88 名でヨット競技は 36 名、平均年齢 $21.1 \pm 6.4$ 才、競技歴 $7.1 \pm 4.4$ 年、ウィ ンドサーフィン（以下WS）競技は52名、27.4土 4.7 才. $8.9 \pm 3.9$ 年であった。主訴は腰痛 51 名、頚・ 肩・背のこり感・鈍痛・つつぱり感（以下肩痛） 22 名、その他15名であった。コンディショニングは 腰痛の鍼治療単独 41 名、鍼治療亡他手技の併用 9 名、他手技 1 名、肩痛の鍼治療単独 17 名、鍼治療と 他手技の併用 4 名、他手技1名であった。治療穴は 腰痛で大腸俞・関元俞・腎俞・気海俞等、肩痛で天柱、 肩井、亳肓、膈俞等であった。鍼治療単独のVAS 值は腰痛（n=41） で治療前 $54.0 \pm 22.7 \mathrm{~mm}$ が後 $20.6 \pm 17.1 \mathrm{~mm} （ \mathrm{p}<0.01 ） 、$ 肩痛（ $\mathrm{n}=17 ）$ で前 59.9 $\pm 20.6 \mathrm{~mm}$ が後 $16.7 \pm 15.2 \mathrm{~mm}$ （p<0.01）で減少した。

【考察と結語】セーリング競技で発生する症状に 対する局所への銊治療は治療前後の VAS 值が減 少したことから、その効果が確認され、競技現場で 行うコンディショニング法のひとつとして鍼治療 は有効であることが示唆された。

キーワード：コンディショニング、腰痛、スポー ツ鍼尒、ヨット競技、銊治療

\section{0-B-15: 12}

鍼刺激が運動に与える影響について

一自転車競技での応用一

明治東洋医学院専門学校

古田高征

兵庫医科大学生理学教室

辻田純三

【目的】近年、競技選手への鍼众施術の報告が多 く行われている。その評価は選手の自覚的疲労度 や筋痛の発生状況に関するものが多く、競技成績 を検討したものは少ない。そこで競技現場での施 術を検討するため、自転車競技の参加選手に鍼众 施術を行い、その影響について競技成績などから 検討した。

【方法】対象は、インフォームドコンセントが得 られた成人男子 6 名で、自転車 4 時間チーム耐久 レースの競技参加者とした。実施手順は被験者を 2 チーム（1チーム 3 人）に分け、周回コースを 2 周毎に交代しながら走行させた。周回のペースは 基本的には各人の自由とした。走行後の被験者は 自由に休息を取らせた。対照群と銊群を設定し、 被験者をランダムに2群に分けた。鍼群では、休 息時間に鍼刺激を行なつた。鍼施術は、大腿四頭 筋を中心に大腿や下腿の全体をローラー鍼（擦過 銊）にて擦過刺激した。測定項目は周回時間や自 覚的運動強度として、周回を経るごとの変化につ いて観察した。

【結果】周回時間は、初回の所要時間と比べると、 対照群では徐々に周回時間が増大する傾向を示し た。しかし鍼群では、若干増大がみられるものの ほぼ初回の所要時間と同等であった。自覚的運動 強度は、初回の走行後を基準とすると、対照群は 周回を重ねるごとに運動強度が上昇する傾向がみ られた。一方、鍼群は対照群に比べ低い傾向が見 られた。

【考察】周回時間や自覚的運動強度は、対照群に 比べ鍼群の変動率が運動の初期と同程度で推移し たことから運動による疲労が対照群より小さかつ たのではないかと推測される。これは今回行った 鍼刺激がローラー鍼による軽度の擦過を行うもの であり、マッサージの様に組織中の血液循環を促 進したためではないかと思われた。

キーワード：自転車競技、ローラー鍼（擦過銊） 


\section{0-B-15:24}

\section{スポーツ選手のコンディショニング に対するSSP療法の効果}

ーランダム化比較試験による検討一

明治鍼尒大学健康鍼尒医学教室

片山憲史、井上基浩、矢野 忠 明治銊尒大学整形外科学教室

勝見泰和、小嶋晃義 明治鍼众大学大学院鍼尒学研究科 北出利勝 龍谷大学トレーニングセンター 堀場久司

【目的】SSP療法は鎮痛や筋緊張の緩和などに広 く用いられているが、スポーツ選手のコンディショ ニング目的に用いた報告はない。そこでSSP療法 を一定期間施行し、コンディショニングにおける 有効性を検討した。

【方法】大学の運動選手18名を対象とし、封筒 法にてランダムに低頻度群 6 名、高頻度群 6 名、 対照群6名（評価のみ）の3群に分け、倫理上の 配慮を十分に行い研究を実施した。SSP療法は低 頻度 $2 \mathrm{~Hz}$ 、高頻度 $50 \mathrm{~Hz}$ で刺激は 10 分間とした。 強度は至適強度より少し強い程度とし、選手の状 態により主に圧痛や反応点のトリガーポイントに 施行した。施術の頻度は週2回とし、評価はオリ ジナルの健康調査表にて毎回施術前に行った。群 間の有意差はMann-WhitneyのU検定を用い、危 険率 $5 \%$ 未満を有意とした。

【結果】スコアの合計は低頻度群67点、高頻度 群64点、対照群56点であった。低頻度群と高頻 度群の間では差はなかったが、対照群とは両群と もに有意に得点が高かった。各項目の平均値では 精神面や全身状態は低頻度、高頻度群ともに差は なかったが、身体面の筋肉疲労、痛み、疲労感に 関して対照群との間で有意な差があつた。特に筋 疲労と疲労感については低頻度群で、痛みについ ては2群ともに対照群と比較し高得点であった。

【考察】両群ともに鎮痛作用は認められたが、高 頻度は低頻度に比較し筋疲労や疲労感の緩和作用 は少なかった。鎮痛作用は内因性オピオイドの関 与が、筋疲労は低頻度では単収縮を、高頻度では 強縮をおこす作用が報告されており、今回の結果 もそれらに由来すると考える。

【結語】低頻度群と高頻度群間では合計点に差は なかったが、対照群との比較では、両群ともに有 意に高得点であった。低頻度群は筋肉疲労や疲労 感と痛みに、高頻度群は痛みに関して対照群と比 較して有意に高得点であったが、精神面や全身状 態に関しては各群間に差はなかった。

キーワード：SSP療法、スポーツ選手、コンディ ショニング、RCT（ランダム化比 較試験)

\section{0-B-15:36 \\ トライアスロン競技中の円皮鍼施鍼 による競技翌日の筋痛回復効果}

\author{
東京医療専門学校
}

金子泰久、古屋英治、坂本 歩

【目的】トライアスロン競技後に発生する筋痛に 及ぼす円皮鍼施鍼効果を検討した。

【方法】対象は平成13年8月11日、平成14年8月 10 日に西湖で行われたトライアスロンレース （51.5 km）に参加した選手、男女121名（年齢 $27.0 \pm 8.3$ 才）とした。被験者には事前に調査内 容、方法について十分な説明を行い、同意を得て 調査を行った。円皮鍼はセイリン株式会社製パイ オネックス鍼（鍼長 $0.6 \mathrm{~mm} 、 0.8 \mathrm{~mm}$ ）およびプラセ ボで、これらの鍼の被験者への割付は乱数表を用 いた。施鍼部位は左右のL2-S1の各棘突起間外方 $2 \mathrm{~cm}$ おび第 2 仙骨裂孔計 10 所であり、レー ス中の施鍼とした。筋痛の評価はVisual Analogue Scale (VAS) 值を用い、レース前後 と翌日に大腿前部・後部、下腿前部・後部、腰部、 慰部の6部位についてアンケート形式で調査した。 統計処理はレース前・後・翌日の各部位毎に、

$0.6 \mathrm{~mm}$ 群、 $0.8 \mathrm{~mm}$ 群、プラセボ群の筋痛をVAS值 として求め、 3 群間で 2 元配置分散分析及び多重 比較を行った。

【結果】レース後のVAS值はレース前に比べ各 群とも全ての部位で有意に増加した。レース後か ら翌日のVAS值の変化は大腿前部においてプラ セボ群 $37.9 \pm 21.4 \mathrm{~mm} \rightarrow 42.8 \pm 22.6 \mathrm{~mm} 、 0.6 \mathrm{~mm}$ 群で $48.3 \pm 21.3 \rightarrow 38.3 \pm 23.4 \mathrm{~mm}$ 、 $0.8 \mathrm{~mm}$ 群で $49.2 \pm$ $23.4 \mathrm{~mm} \rightarrow 34.2 \pm 22.9 \mathrm{~mm}$ となり、0.8mm群のVAS值 が有意（p<0.05）に減少した。他部位においても 円皮鍼群のレース翌日のVAS值はレース後と比 較して有意に減少あるいは減少傾向であった。

【考察・結語】トライアスロン競技中の腰部への 円皮鍼施鍼によって翌日の筋痛が抑制された。競 技中ばかりでなく日常のトレーニングでも円皮鍼 の腰部への施鍼は、トレーニングによって発生す る腰下肢の負担を軽減し、効率良いトレーニング を実施できると考えられる。

キーワード：トライアスロン、円皮銊、筋痛、ト レーニング、鍼治療 
20-B-15: 48

\section{鍼炎療法とコンディショニング}

一非侵襲的施術と解剖生理学的原理一

防衛医科大学校解剖学第一講座

竹内京子

筑波大・体育センター

進藤正雄

埼玉東洋医療専門校

一の瀬宏

国立身障者リハビリテーションセンタ一理療教育 部

舘田美保

日本柔整鍼尒専門学校

小比賀黎子

【目的】運動選手のコンディショニングは、個々 の選手の様々な要求を $100 \%$ 満たすことが望まれ ているが、我々は、この条件を満たすべく可能な 限り安全でかつ著効が得られる施術方法を検討し ている。今回は非侵襲的施術の効果および作用機 序について解剖生理学的に考察を加えたので報告 する。

【方法】対象は運動クラブ所属（サッカー、陸上 競技その他）の高校生、大学生、社会人と一般成 人男女合計 148 名である。施術の種類は、鍉鍼、 台座尒、電子鍼、手技療法、チップ類貼付（チ夕 ン系、遠赤系、布・テープ等）である。刺激の強 さは本人の感覚を優先し、気持ち良く受け入れら れる程度とした。施術部位は個人により異なるが、 通常2-3個所である。評価は、本人の感想、姿勢・ 関節可動域の変化、エコー像の変化、障害からの 回復状況、運動パフォーマンスの改善などで行なつ た。

【結果と考察】非侵襲的療法は皮膚など組織への 侵襲がない、施術直後も運動が可能、緊張緩和・ 消炎鎮痛に著効ということで非常に好評であった。 エコー像にも変化が認められた。障害が重篤なほ ど強い刺激に鈍感であつたが、弱い刺激の方が効 果は著しかつた。金属系の刺激効果は著しく、衣 服の上からでも著効があった。皮膚へ持続刺激は、 時に副作用として、非刺激部位につり感や冷感が 生じたが、これは刺激量過多が原因と思われる。 人と人あるいは人と物体間に電位差がある時、両 者が接触すると必ず電流が流れる。施術部位に生 じた電流が更なる刺激となつて自律神経系に作用 していると考えられるが、今回の結果から、非侵 襲的刺激は副交感神経系へ優位に作用しているも のと示唆される。

【結語】競技力低下をもたらすことなく、疲労や 障害からの回復を図るためには、施術は楽にトレー ニングができる身体造りを目指す必要があるが、 今回の方法はこの目的に適うものである。

キーワード：スポーツ鍼尒、コンディショニング、 副交感神経系、非侵襲的施術
20-C-09:00

\section{便通異常に対する鍼治療の効果に関 する臨床研究}

明治鍼尒大学健康鍼尒医学教室

岩 昌宏

明治鍼尒大学臨床鍼尒医学 II 教室

今井賢治

明治鍼尒大学外科教室

田村隆朗、咲田雅一

【目的】鍼尒治療が便通異常に効果があるとされ ているにもかかわらず、研究報告はほとんどない のが実状である。今回はさらに詳細に便通異常に 対する鍼治療の効果を明らかにするために、便通 異常を有する被験者を銊群とシャム銊群に分け、 比較検討したので報告する。

【方法】対象：本学学生419名を対象に排便に関 するアンケート調査を行った。排便に不快感を 有する者 22 名を鍼群（11名）とシャム鍼群 （11 名）の2群に無作為に分けた。

治療方法：治療穴は足三里とし、鍼群では鍼体長 $1.2 \mathrm{~mm}$ の円皮鍼（セイリン社製pyonex）を使 用し、シャム群ではテープのみを貼付した。

研究行程 : 治療前、中、後をそれぞれ 3 週間とし、 治療期間には週2回、計6回の円皮銊及びテー プの貼り替えを行つた。全期間にわたつて排便 日誌を記録させた。

評価：途中8名が脱落したため14名（鍼群9名、 シャム群5名）を対象とした。「排便回数」、 「排便量」、「便性状」、「残便感」「「排便時の腹 痛」「鬼粪便の有無」の6項目について比較検 討した。

【結果】排便量：シャム群5名全員が変化なかっ たのに対して、鍼群では9名中5名が改善して いた。

便性状：シャム群5名全員が変化なかったのに対 して、鍼群では9名中7名が普通便へと改善し ていた。

鬼粪便の有無：シャム群5名全員が変化なかつた のに対して、鍼群では6名中4名が減少してい た。

排便時の腹痛 : 排便時の腹痛の割合の平均值を見 ると、シャム群では治療前 $36.7 \%$ 、治療中 33.5 \%、治療後 $43.5 \%$ と増加しているのに対して、 銊群では治療前 $42.5 \%$ 、治療中 $26.2 \%$ 、治療後 $24.1 \%$ と減少していた。

\section{【考察と結語】}

足三里への鍼刺激が便秘や下痢、交代性便通異 常などのそれぞれタイプの異なつた便通異常を改 善する傾向が認められた。特に排便量や便性状な どに影響を及ぼし、付随する残便感や腹痛などを 軽減さるのではないかと考えられる。

キーワード：便通異常、鍼治療、円皮鍼、シャム 銊、足三里 
20-C-09:12

\section{便通異常に対する鍼炎治療の効果に ついて}

-1 事例研究法（反転法）による検討一

明治銊尒大学内科学教室

松本 淳、小野公裕、苗村健治、山村義治 明治鍼众大学健康鍼尒医学教室矢野 忠 明治鍼众大学鍼尒臨床医学 I 教室石崎直人

【緒言】過敏性腸症候群（以下、IBS）を始めと する便通異常は、近年増加傾向にある。それらの 患者は、全身の愁訴や心理的異常を伴うことが多 く、従来の治療に抵抗するものも多い。今回、 IBS を中心に便通異常を有する患者に対し鍼炎治 療を行い、反転法により臨床効果を検討した。

【対象及び方法】当院内科に通院しIBSと診断さ れた患者4名。全員が罹病期間 1 年以上で、半年 以上の投薬によっても症状の完全な改善が得られ なかった患者であった。鍼炎治療は、各患者に対し 中医学的な弁証を行い、随時配穴した。治療期間 は10回ないし20回を1クールとし、無治療期間と 交互に繰り返した。便通異常の評価は、排便日誌 をもとに、腹痛の程度 (VAS、マクギル・メルザッ ク式痛みアンケート $[\mathrm{MPQ}]$ )、腹部膨満感、排便回 数、便性状等を記録した。また全身状態（フェイス スケールと明治鍼尒大学式弁証スコアー [MOS])、 心理状態 (Self-rating Depression Scale [SDS]、 と Profile Of Mood States [POMS]) 、QOL (Gastrointestinal Symptoms Rating Scale [GSRS〕）についても合わせて評価した。

【結果】1クール終了時には、4例中3例において 腹痛、腹部膨満感、全身状態が軽減したが、無治 療期間中には増悪するものもあった。QOLも同 じ3例で治療期間毎に改善したが、無治療期間中 には増悪した。残りの1例は治療期間中に、腹痛 のみMPQにおいて改善を認めたが、無治療期間 中は増悪した。心理状態については一定の傾向は 見られなかった。症状の変化に伴い服薬量は2例 で減少し、1例で増加した。

【考察と結語】今回の治療期間及び無治療期間の 経過から、鍼尒治療が便通異常における腹痛等の 症状軽減に有効である可能性が示唆された。

キーワード：過敏性腸症候群、腹痛、便通異常、 反転法、鍼炎治療

\section{0-C-09: 24 術後腸管機能に対する円皮針の影響}

明治銊尒大学外科学教室

中西博文、田村隆朗、咲田雅一 明治鍼众大学健康鍼尒医学教室 岩 昌宏

【目的】開腹外科手術後の数日間は麻酔や手術侵 襲の影響で腸管機能が低下する。多くの場合、腸 管機能は徐々に回復するが、なかには遷延する症 例もあり、なるべく早期に回復することが望まし い。そこで術後腸管機能の早期回復を目的に、手 術直後から予防的に円皮針を行うことで術後の腸 管機能の回復過程にどのような影響を与えるのか を比較検討した。

【方法】全身麻酔下で開腹外科手術が施行された 患者10名を対象とした。手術終了直後から両側 の合谷穴および足三里穴に円皮針を貼り付けた。 円皮針はセイリンJr（セイリン社製）を用いた。 円皮針は週3回貼り換え、術後2週間継続して行っ た。評価は開腹外科手術を受け、円皮針を受けな かつた患者を対照群として円皮針群と比較した。 胃腸管の切断を伴わない手術 (A) と胃腸管の切断 を伴う手術 (B) に分類し、腸動確認時間、初発排 ガス時間、初発大便時間、経口摂取開始時間を比 較した。

【結果】対照群に比べて円皮針群においてすべて の項目で明らかな時間の短縮がみられた。特に $\mathrm{A}$ では腸動確認時間、初発大便時間に短縮がみられ た。Bでは腸動確認時間、経口摂取開始時間に短 縮がみられた。

【考察と結語】円皮針は簡便で患者への負担が少 なく、持続して刺激を与えることが可能である。 今回の研究ではそれぞれの回復過程において時間 の短縮がみられたことより、開腹外科手術後の腸 管機能の早期改善に円皮針が有用であることが示 唆された。

キーワード：円皮針、鍼治療、術後腸管機能、開 腹外科手術 


\section{0-C-09:36 \\ 麻酔ラットの小腸運動に対する鍼通 電刺激の効果とメカニズム}

筑波技術短期大学鍼众学科

野口栄太郎、大沢秀雄

筑波大学附属盲学校

志村まゆら

【目的】前回の本学会において、鍼通電刺激によ り小腸運動が亢進または抑制することを報告した。 今回は鍼通電刺激が、小腸のどの部位にどのよう な影響およぼすのかを検討する目的で、測定部位 を空腸部と回腸部に分けて鍼通電刺激効果とその メカニズムについて検討した。

【方法】実験は、ウレタン麻酔人工呼吸下のラッ トを用い、空腸運動は幽門部より約 $15 \mathrm{~cm}$ 肛門側 で、回腸運動は虫垂より $15 \mathrm{~cm}$ 口側にバルーンカ テーテルを挿入し、2 所の小腸内圧の変化を同 時に観察した。実験終了後に胃から虫垂部までを 摘出し測定部位を計測した。刺激は鍼通電刺激と 小腸部での迷走神経の関与を明らかにする目的で、 大内臓神経と迷走神経を刺激した。

【結果】腹部鍼通電刺激と大内臓神経刺激により 空腸・回腸運動の抑制が観察された。腹部鍼通電 刺激による空腸・回腸内圧減少反応が内藏神経の 切断で消失した。空腸運動とは異なり、後肢足蹠 鍼通電刺激による回腸運動の反応は、約 $81 \%$ が 無反応で $19 \%$ に進反応が認められ、さらに迷 走神経刺激による回腸運動の克進反応は認められ なかつた。

【考察と結語】腹部鍼通電刺激による回腸運動反 応は胃・十二指腸・空腸運動と同様に交感神経を 介した抑制反応と考えられた。足蹠刺激により少 数例で観察された回腸運動六進反応の機序は、内 臓神経を介することが示唆された。

キーワード：鍼通電刺激、空腸運動、回腸運動、 迷走神経、ラット
20-C-09:48

\section{ラット結腸運動に対する鍼通電刺激 の影響 \\ 一通電頻度の違い、及びその作用機序の検討一}

明治鍼尒大学外科学教室 前原伸二郎、咲田雅一 明治鍼尒大学健康鍼尒医学教室岩 昌宏

【目的】我々はこれまでに直腸拡張刺激による結 腸運動抑制反応に対する鍼通電刺激（EA）の効 果について検討し、EAが結腸運動を元進させる 可能性を報告した。また、その作用機序として消 化管ホルモンであるコレシストキニン（CCK） が中枢レベルで関与していると推測されるが、詳 細については不明である。そこで今回、まず結腸 運動に対するEAの通電頻度の違いによる影響を 観察し、次にその作用機序に中枢のCCKが関与 しているか明らかにするために、CCK受容体拮 抗薬の脳室内投与実験、及びEA後の脳脊䯣液中 のCCK濃度測定を行つた。

【方法】実験動物はWistar系雄性ラットを用い た。結腸運動に前駆して発生する平滑筋の電気活 動（LSB）を記録するための電極を結腸漿膜面に 縫着した。実験 1 : 刺激前值として30分間のLSB を記録し、その直後より後肢へのEAを30分間行 い、刺激後も60分間、LSBを記録した。なお、 通電頻度は3、15、100 Hzとしその影響の違いを 比較した。実験 2：CCK-A（CR-1505)、CCK-B (L-365,260) の2種類の受容体拮抗薬を、それぞ れEA前に $5 \mu \mathrm{g} / 5 \mu \mathrm{l} / 10$ 分間で脳カニューレより 脳室内投与し、その影響を観察した。実験 3 : 脳 春髄液をEA前、EA30分後、EA60分後に採取し、 CCK濃度をRIA法を用いて測定した。

【結果・考察】実験 $1: 100 \mathrm{~Hz}$ のEAによりEA後 60分間にわたり結腸のLSBの有意な増加を示し たが、3、15HzではLSBの変化が認められなかつ た。実験 $2 ： 100 \mathrm{~Hz}$ の EA による LSB の増加は $\mathrm{CCK}-\mathrm{A}$ 受容体拮抗薬の脳室内投与によって拮抗 されたが、CCK-B受容体拮抗薬投与では拮抗さ れなかった。実験 $3: 100 \mathrm{~Hz}$ のAによって脳脊 髄液中のCCK濃度はEA30分後に有意に増加した が、3HzのEAではCCK濃度の増加が見られなかっ た。以上の結果より、100HzのEAによって中枢 に放出されたCCKが中枢のCCK-A受容体を介し て結腸運動を亢進する可能性が示唆された。

キーワード：結腸運動、鍼通電刺激、CCK、LS B、脳脊髄液 


\section{0-C-10:00 \\ 胃電図を指標とした腹部外科手術後 の胃機能に対する円皮鍼の影響}

明治鍼尒大学外科学教室

市川由美子、塩見真由美、田村隆朗、咲田雅一 明治鍼尒大学臨床鍼尒医学 II 教室今井賢治

【目的】腹部外科手術侵襲により消化管機能は抑 制され、胃においても運動の抑制と異常筋電図の 出現することがすでに知られている。特に異常筋 電図は胃電図による評価が可能であり、手術直後 には速波や遅波などの異常波形が出現し、時間経 過と共に3cycles/min.の正常波へと復すること をすでに確認した。今回は、手術直後から円皮鍼 による刺激を行い、術後の胃機能の回復を促進で きるかどうかを検討した。

【方法】全身麻酔下で腹部外科手術が施行された 患者14名（男性8名、女性6名。平均年齢75.6歳） を、円皮鍼群7名、非円皮鍼群7名に分けた。円 皮鍼はセイリンJrを使用し、手術終了直後から両 側の合谷穴および足三里穴に貼付した。手術終了 直後から胃電図の記録を開始し、翌朝9時まで継 続して行った。尚、記録にはポータブル型胃電計 (ニプロ社製)を用い、解析は専用のソフトでFFT を行い power spectrumを描出した。0〜9 $\mathrm{cycle} / \mathrm{min}(\mathrm{cpm})$ の帯域を胃電図の成分とみな 乙遅波成分 $(0 \sim 2 \mathrm{cpm})$ 、正常波成分 $(2 \sim 4 \mathrm{cpm})$ 、 速波成分 $(4 \sim 9 \mathrm{cpm})$ の占める割合を算出し、 その経時的推移を両群で比較した。

【結果】両群共に手術直後には胃電図の異常波形 の占める割合が高く、正常波の占める割合を上回つ ていた。しかし、正常波成分の経時的な推移に着 目すると、非円皮鍼群に比へ、円皮鍼群でその占 める割合が高く推移していた。特に、術後10時 間では、円皮鍼群で正常波の占める割合が $60 \%$ を越え術前のレベルに復したのに対し、非円皮鍼 群では約50\%と低値を示したままであった。

【考察】両側の合谷穴および足三里穴に円皮鍼を 貼付することで、術後の胃機能の回復を促進でき 得る可能性が示唆され、その評価に胃電図を応用 することは妥当であるものと思われた。

【結語】円皮鍼群では非円皮鍼群に比べ、術後に 出現する胃電図の異常波形の占める割合が低く、 正常波成分の占める割合が高く推移していた。

\section{0-C-10: 12 \\ 尿失禁を呈する過活動膀胱に対する 鍼治療の有用性}

明治鍼众大学臨床鍼众医学 II 教室

本城久司、北小路博司

京都府立医大泌尿器科学教室

浮村 理、小島宗門、三木恒治

明治鍼众大学泌尿器科学教室

斉藤雅人

【目的】我々は頻尿、尿失禁に対する銊治療の有 用性を報告してきた。今回、尿失禁を呈する過活 動膀胱患者に対する鍼治療の効果を検討した。

【方法】尿失禁を伴う過活動膀胱を有する患者 40 例（男性27例,女性13例）に銊治療を施行した。 過活動膀胱の原因疾患は脳血管障害およびパーキ ンソン病を含む脳神経障害患者 22 例と脊髄損傷 患者18例であった。脳神経障害患者全例に脳 MRI を施行し障害部位を特定した。銊治療は第3 後仙骨孔部の中髎穴 (BL-33) に直径 $0.3 \mathrm{~mm}$ 、 長さ $60 \mathrm{~mm}$ のディスポーザブル鍼を刺入した後、 鍼を半回旋する旋撚刺激を左右合計 10 分回行う ことを 1 回の治療とし、週1回で計 4 回施行した。 1 ケ月治療直後の評価のため鍼治療前と鍼治療 4 回終了1週後にウロダイナミクス検查を施行し比 較検討した。さらに、鍼治療前と鍼治療4回終了 の1週間での排尿記録による尿失禁量を評価した。 その後、月1回の維持療法を原則として行い長期 の治療効果も評価した。

【結果】尿失禁が消失した症例は8/40（20\%） で、尿失禁量が50\%以上改善した症例は $20 / 40$ (50\%) であった。ウロダイナミクスによる治療 評価では、膀胱容量が $110.1 \pm 57.9 \mathrm{ml} ら 178.7$ $\pm 84.4 \mathrm{ml}$ に有意（ $\mathrm{p}<0.0001 ） に$ 変化した。脳神 経障害患者 22 例のうち、膀胱容量の増大のみら れなかった症例は6例あり、5例に前頭葉の広範 な梗塞とラクネが明らかに描出されていた。また、 月 1 回の維持療法が有効な症例を 10 例経験した。 なお特記すべき合併症はなかうた。

【考察】中髎穴の銊治療は膀胱容量を増大させる ことにより、尿失禁の改善に寄与したと考えられ た。また、脳神経障害患者において、前頭葉の著 しい障害は鍼治療による尿失禁治療が困難な対象 であると考えられた。

【結語】鍼治療は膀胱容量を増大させ、尿失禁治 療に有用な低侵襲的治療の選択枝と思われる。

キーワード：尿失禁、過活動膀胱、銊治療 
20-C-10:24

鍼刺激が尿噴流に及ぼす影響に関す る検討

明治銊众大学泌尿器科学教室

手塚清恵、冨田賢一、斉藤雅人

明治鍼众大学鍼众臨床医学 II 教室

本城久司、北小路博司

【目的】鍼刺激が尿噴流に及ぼす影響について、 超音波カラードプラ法を用いて検討したので報告 する。

【方法】18～26歳（平均年齢23歳）の学生ボラ ンティア 20 名（男性10名、女性10名）を対象に 行った。実験 3 時間前に $350 \mathrm{ml}$ の飲水負荷を行い、 以後絶飲食とするように各対象者に指導した。尿 噴流の測定項目は5分間における尿噴流の出現頻 度、最高流速、持続時間とした。さらに腎臓の血 流動態を検索するために腎葉間動脈の Resis tance Index（RI）を測定し検討した。刺激部位 は中極穴（CV3）を選択し、鍼刺激は通電刺激、 捻鍼刺激とし、それぞれ日を変えて15分間行つ た。また無刺激をコントロールとした。

【結果】尿噴流の出現頻度、最高流速は刺激前值 に比べて通電刺激群と捻鍼刺激群で増大したが、

コントロール群では変化がなかった。持続時間は 通電刺激群と捻銊刺激群で短縮がみられたが、コ ントロール群では短縮する傾向が観察された。腎 血流動態の指標のひとつであるRIは全群で変化 がみられなかった。

【考察と結語】中極穴への銊刺激は尿管機能に作 用し、蠕動運動を促進させると考えられた。

キーワード : 鍼刺激、尿噴流、カラードプラ法、 超音波

\section{0-C-10:36 \\ 第 II 期前立腺肥大症に伴う排尿障害 に対する鍼治療の 1 症例}

明治鍼尒大学泌尿器科学教室

冨田賢一、手塚清恵

明治鍼尒大学臨床鍼尒医学 II 教室

北小路博司、本城久司

明治鍼众大学大学院修士課程

谷口博志

明治鍼尒大学健康鍼众医学教室

矢野 忠

【目的】高齢化社会を迎え、加齢によって起こる と考えられる排尿障害の出現は高齢者のQOL低 下を招く要因となっている。これまで、第 I 期前 立腺肥大症に対し鍼治療の有効性が報告されてい る。しかし、手術適用とされる第 II 期前立腺肥大 症への鍼治療が有効であったとされる報告はされ ていない。今回、夜間頻尿を主訴とし第 II 期前立 腺肥大症患者に対し鍼治療を行い、症状の改善が 見られたので報告する。

【症例】[患者］75歳男性。[現病歴］平成13年 9月夜間排尿時に腹圧をかけないと排尿できない 状態になり、近医泌尿器科を受診。前立腺肥大症 と診断され、 $\alpha 1$ ブロッカーを処方された。医師 には手術を勧められたが、拒否。平成 14 年6月、 夜間頻尿の改善を目的に明治銊尒大学附属鍼尒セ ンター、専門外来を受診した。[所見］排尿症状 は夜間頻尿が5〜 6回、残尿感 $(+)$ 、尿失禁 $(-)$ 、 排尿時痛 (一)、国際前立腺肥大症症状スコア (以下IPSS) が23点。前立腺重量は $37 \mathrm{~g} 。$ 超音波 検查にて $65 \mathrm{ml}$ の病的残尿を確認した。

【治療方法】中髎穴（BL-33）にセイリン化成社 製鍼尒鍼（直径 $0.30 \mathrm{~mm} \times$ 鍼長 $60 \mathrm{~mm}$ ）を用いて、 刺入後 10 分間捻鍼を行った。治療は7回目までが 週に1回、以降は月 1 回の間隔で計 9 回行った。評 価は排尿日誌、尿流測定、IPSSにて行った。

【結果】治療前は夜間排尿が5.14（ $\pm 0.69 ）$ 回。 IPSSが23点。平均尿流率 (以下AFR)が $5.7 \mathrm{ml} / \mathrm{s}$ 。 治療7回で夜間排尿が2.71（土2.71）回。IPSSが 15点。AFRが $8.4 \mathrm{ml} / \mathrm{s}$ と改善が見られた。

【考察と結語】今回、手術適用とされる第 II 期前 立腺肥大症患者に対し銊治療を行つた結果、良好 な結果を得た。夏季から冬季になつても症状の増 悪は見られず、治療間隔も1ヶ月に1回程度の鍼 治療で症状は安定しており、患者のQOLの向上 に鍼治療が貢献していると考えられた。

キーワード：前立腺肥大症、鍼治療 


\section{0-C-10:48 \\ 脳梗塞ラットによる過活動膀胱に対 する覚醒下鍼刺激の検討}

明治鍼众大学臨床鍼尒医学 II 教室

北小路博司、本城久司、谷口博志、冨田賢一 明治鍼尒大学大学院第3基礎医学教室 渡邉 泱 明治銊尒大学生理学教室喜田健司 明治鍼尒大学薬理学教室栗山欣彌

【目的】過活動膀胱の患者に対して仙骨部の鍼刺 激を行うと膀胱容量の増大が生じ、尿失禁が改善 することを報告した。しかし、膀胱過活動モデル の覚醒下における鍼刺激の基礎的検討は報告がな い。今回、脳梗塞ラットによる排尿反射の元進に 対する鍼刺激の影響を検討したので報告する。

【方法】S-D系雄性ラット（9～10週齡：体重約 340g） 7 匹を用い麻酔下 (pentobarbital sodium）で膀胱瘦カテーテル固定し、ボールマ ンゲージ内で覚醒下に生理食塩水を $0.2 \mathrm{ml} / \mathrm{min}$ 持続注入し膀胱内圧測定を行った。このときの膀 胱容量をControl值とした。後日、左中大脳動脈 を永久閉塞した脳梗塞ラットモデルを作成し同様 の方法にて膀胱容量を測定した。このときの膀胱 容量を梗塞後值とした。次に、仙骨部に鍼尒針で 1 分間刺激を行い、鍼刺激後の膀胱容量を鍼刺激 後值とした。評価はControl值、梗塞後值および 鍼刺激後値の各膀胱容量とした。統計学的検討は、 多重比較検定の Tukey 法を用いて (Stat ViewJ5.0)、危険率 $5 \%$ 以下を有意とした。

【結果】膀胱容量は、Control值 $1.7 \pm 0.8 \mathrm{ml}$ (平 均土標準偏差）に比べ梗塞後値 $0.5 \pm 0.3 \mathrm{ml}$ と有意 な（ $\mathrm{p}<0.05 ）$ 膀胱容量の減少がみられた。鍼刺激 後值は $0.9 \pm 0.5 \mathrm{ml}$ でControl值との間に有意な差 はなかった。

【考察・結語】脳梗塞ラットモデルの排尿反射の 亢進に対して、仙骨部の鍼刺激は排尿反射の六進 を抑制し、膀胱容量を増大させることが考えられ る。

キーワード : ラット、脳梗塞モデル、過活動膀胱、 覚醒下、銊

\section{0-C-14:00 \\ 糖尿病性勃起障害に対して鍼治療が 有効を示した 1 症例}

明治鍼众大学附属鍼尒セン夕-11

明治鍼尒大学大学院鍼尒臨床医学 ${ }^{21}$

明治鍼食大学臨床鍼尒医学 II 教室 ${ }^{3)}$

谷口博志 ${ }^{1.2)}$ 、矢野 忠 ${ }^{1,2)}$ 北小路博司 ${ }^{1,3)}$ 本城久司 ${ }^{1,3)}$ 、冨田賢一 ${ }^{1,3)}$

【目的】糖尿病を有する男性の約半数は勃起障害 (Erectile Dysfunction以下ED) を合併するとい われている。今回、糖尿病性EDに対してクエン 酸シルデフィル（以下、バイアグラ）の薬物療法 が施行されるも抵抗を示した症例に鍼治療を行い、 有効性が見られたので報告する。

【対象】61歳・男性。平成13年1月に雪かきをお こなっていたところ四肢に感覚がなくなるほど冷 えを感じ、その後EDが発症した。同年の9月に 国立舞鶴病院泌尿器科を受診し、糖尿病性神経障 害によるEDと診断され、バイアグラ $50 \mathrm{mg}$ を処 方された。バイアグラを2、3回服用することに より、改善が見られたものの、その後効果がなく なったので、知人の紹介にて本学附属鍼尒センター の受診となった。初診時の性機能所見は、早朝勃 起なし、性交時の勃起なし、国際勃起障害機能又 コア5（以下、IIEF5）は9点であった。

【治療と経過】鍼治療は週1回の間隔で合計 31 回 行った（平成14年12月現在）。1回目〜 5 回目は 中髎穴に旋撚術を行ったところ早朝勃起がみられ、 性交時に勃起が可能で硬度も約 $60 \%$ まで改善し た。また、IIEF 5 は17点と改善がみられた。よ り高い効果を期待して6回目〜25回目は銊治療部 位を陰部神経刺鍼点の鍼通電療法に変更したとこ ろ、性交時の陰茎の感覚が改善したが、他の所見 にさらなる変化はみられなかつた。そこで 26 回 目以降は、鍼治療部位を陰部神経刺銊点と中髎穴 の鍼通電療法に変更したが、早朝勃起、性交時の 勃起硬度、IIEF5いずれにおいても増悪、緩解は なく、性交時の勃起硬度は60\%〜 70\%で、ED罹 患前までは回復しないものの、性交渉を試みた時 は、勃起障害の定義である「75\%以上性交が行え ない状態」を上回るまで性機能が回復した。なお、 現在も鍼治療は継続中である。

【結語】今回、糖尿病によるEDに対して銊治療 を行った結果、早朝勃起や性交時の性機能に改善 がみられた。このことより、糖尿病性勃起障害に 対して鍼治療が有効であることが示された。

キーワード : 勃起障害、糖尿病性神経障害、鍼治 療、IIEF5 


\section{0-C-14: 12}

\section{鍼治療により改善した糖尿病性胃運 動異常の 1 症例}

明治鍼尒大学内科学教室

米田裕和、福井和佳子、小野公裕、山村義治 明治鍼尒大学臨床鍼尒医学 II 教室 今井賢治 明治鍼尒大学臨床鍼尒医学 I 教室 石崎直人 明治鍼尒大学健康鍼众医学教室 矢野 忠

【目的】糖尿病患者は胃運動異常を合併する場合 が多く、それが血糖コントロールの妨げになるこ とがある。今回我々は、胃電図に異常を認めた 2 型糖尿病の 1 例に対して鍼尒治療を施行し、症状 と胃電図所見に改善を認めたので報告する。

【症例】73歳、女性。1996年に糖尿病と診断さ れ、1999年より薬物療法を開始した。その後通 院加療していたが、2001年1月頃より HbA1cが 徐々に高值を示し、14\% 前後を示したため、 2002 年 8 月当院内科に教育入院となった。入院 時に腹部膨満感があり、胃電図検査により、胃運 動異常が疑われたため、鍼众治療を試みた。

【結果】入院時の胃電図所見は、空腹時の律動異 常を認め、飲水負荷後に通常診られる周波数の徐 波化が久如していた。6日間の経過観察後には、 飲水負荷に対し振幅は増大したものの、依然とし て周波数の徐波化は認められなかった。しかし、 翌日に再度行った胃電図検査中に足三里の鍼刺激 を加えたところ、銊刺激中に正常波成分が増大し、 その後の飲水負荷に対しては、周波数の徐波化を 認める反応を示した。その後、足三里、内関への 銊治療を週2回の割合で継続したところ、治療4 回終了時（退院時）には、空腹時の正常波成分が 鍼众開始時に比べて増大し、飲水負荷に対して周 波数の徐波化を認める反応を示し、腹部膨満感は 消失した。

【考察】約 1 週間の血糖コントロール行った限り では、依然として腹部膨満感は改善しなかったが、 胃電図では若干の改善がみられた。しかし、翌日 の胃電図検査では銊刺激中に改善を認め、飲水負 荷に対しても正常な反応を示した。さらに継続的 な鍼众治療を施行したところ、腹部膨満感は消失 し、胃電図は正常波成分の増大及び周波数の飲水 負荷による徐波化が認められた。

【結語】鍼炎治療が糖尿病性胃運動異常を改善し た可能性が示唆された。

キーワード : 糖尿病、胃電図、胃運動、鍼治療

\section{$20-C-14: 24$ \\ 糖尿病に対する鍼治療の 1 症例}

東洋医学研究所 ${ }^{\circledR}$

山田 篤、中村弘典、黒野保三

【目的】1997年に厚生省が行った糖尿病実態調 査では、我が国の糖尿病患者は予備軍を含めると 約1370万人と言われている。このことから、鍼 众院に来院する糖尿病患者は増加するものと思わ れる。今回の症例は、親戚から瘦せたと指摘され 心配になり、検査を受けたところ糖尿病と診断さ れた患者に対して鍼治療を行ったところ、血糖コ ントロールが良好な状態に改善されたので報告す る。

【症例】患者は82歳女性、主訴は糖尿病・瘦せ が気になる。治療方法は全身の調整を目的とした 太極療法（黒野式全身調整基本穴）とした。銊治 療期間は平成 12 年 10 月 27 日から平成 13 年 5 月 1 日 までの188日間（42回）で、治療頻度は原則とし て週2回とした。治療経過はへモグロビン $\mathrm{A}_{1 \mathrm{c}}$ と 空腹時血糖值から血糖コントロールの状態を検討 すると同時に、（社）全日本鍼尒学会愛知地方会研 究部生活習慣病班糖尿病カルテを使用して症状の 推移を客観的に検討した。

【結果】鍼治療直後のへモグロビン $\mathrm{A}_{1}$ は $10.0 \%$ 、 空腹時血糖值は $190 \mathrm{mg} / \mathrm{dl}$ 、糖尿病自覚症状点数 は16点だったのが、最終時のへモグロビン $\mathrm{A}_{1 \mathrm{c}}$ は $5.9 \%$ 、空腹時血糖值は $97 \mathrm{mg} / \mathrm{dl}$ となつた。また、 糖尿病自覚症状点数は8点となり、効果判定は有 効だつた。

【考察】鍼治療により全身を調整したことにより、 インスリン分泌率の低下であったものが改善され て上昇したものと考えられ、糖尿病に伴う症状の 改善が見られた。

【結語】全身調整を目的とした太極療法としての 銊治療を行った結果、血糖コントロールが良好な 状態になり、糖尿病自覚症状点数が減少した。こ のことから、銊治療が糖尿病に対して有効である ことが示唆された。

キーワード : 糖尿病、血糖值、へモグロビン $\mathrm{A}_{1 \mathrm{c}}$ 、 太極療法（黒野式全身調整基本穴）、 糖尿病力ルテ 
20-C-14:36

\section{糖尿病モデル動物に対する鍼治療の 効果 (IV)}

一全身麻酔糖尿病ラットにおける検討一

東洋医学研究所 ${ }^{\circledR}$ グループ ${ }^{11}$ 、名古屋市立大学大 学院医学研究科細胞機能制御学分野 ${ }^{21}$

中村弘典 ${ }^{1,2)}$ 、黒野保三 ${ }^{1,2)}$ 、石神龍代 ${ }^{1,2)}$ 堀 茂 ${ }^{1,2)}$ 、河瀬美之 ${ }^{1,2)}$ 、山田 篤 ${ }^{1,2)}$ 皆川宗徳 ${ }^{11}$ 、鈴木 光 $^{2)}$

【目的】我々は、第51回 (社) 全日本鍼众学会学 術大会において、全身麻酔下では鍼治療効果を完 全には抑制できないことから、鍼治療効果には脳 を介さない機序の存在が推察されることを報告し た。そこで、今回はSTZ糖尿病ラットに対する銊 治療効果の機序が末梢に存在することを解明する ため、全身麻酔糖尿病ラットに、さらに皮膚粘膜 の局所麻酔を加え鍼治療の有効性を検討したので 報告する。

【方法】実験には6週齢で体重約 $170 \mathrm{~g}$ の Wistar 系雄性ラットを用いた。ラットは9群に分け、I 群：コントロール (3匹)、I群 : STZ糖尿病（7 匹)、正群 : STZ+鍼治療 (8匹)、IV群 : STZ+ 全身麻酔十銊治療、V群: STZ+局所麻酔（皮膚 粘膜）十鍼治療（8匹）、VI群 : STZ+全身麻酔 十局所麻酔＋鍼治療（8匹）とした。糖尿病ラッ トは、STZ60mg/kgを腹腔内に投与して作成し た。全身麻酔はペントバルビタールを腹腔内に $50 \mathrm{mg} / \mathrm{kg}$ 投与し、皮膚粘膜の局所麻酔は銊治療 部位にキシロカインを塗布した。銊治療は週2回、 経穴は中脘・天枢・気海・肝俞・脾俞・腎俞に切 皮程度に治療を行った。空腹時血糖值は、20時 間絶食後簡易血糖測定器で測定した。

【結果】鍼治療群は、前回の実験結果と異なり、 STZラット群、STZ+麻酔十鍼治療ラット群及び $\mathrm{STZ}+$ 全身麻酔十局所麻酔＋鍼治療ラット群に比 ベ空腹時血糖值の低下傾向が認められたものの有 意な差は認められなかった。また、体重において も、鍼治療群は他の鍼治療ラット群と比べ体重の 増加傾向が認められたが、有意な差は認められな かった。

【考察・結語】今回の結果から、全身麻酔及び 局所麻酔により鍼治療効果が軽減し、さらに全身 麻酔と局所麻酔の両方を処置し鍼治療を行ったと ころ、全身麻酔のみや局所麻酔のみに比べ、鍼治 療の効果が軽減傾向にあった。このことから鍼治 療効果の機序の存在が中枢と末梢の双方にあるこ とが考えられる。

キーワード : 糖尿病、ストレプトゾトシン (STZ)、 空腹時血糖値、ラット、鍼治療
20-C-14:48

非代償性肝硬変症に対する鍼治療の 検討

東洋医学研究所 ${ }^{\circledR}$ グループ

服部輝男

東洋医学研究所

東京大学大学院情報学環

黒野保三

伊藤陽一

【目的】非代償性肝硬変症と診断され、腹水の貯 留、消化管出血、黄疸、肝性脳症などで入退院を 繰り返していた患者が腰痛を訴えて来院してきた。 問診の結果、肝硬変症の治療が重要と考え腰痛と 並行して鍼治療を行ったところ興味ある結果が得 られたので報告する。

【症例】患者：69歳、女性。現病歴：近医より $\mathrm{K}$ 病院に転院して汎血球減少、T.BiL、アンモニ ア值の上昇、コレステロールの減少などが見られ 非代償性肝硬変症と診断された。治療方法：30 $\mathrm{mm} 、 16$ 号ステンレスディスポ鍼を使用し単刺 術及び置鍼術にて、生体の総合的統御系の活性化 を目的とした太極療法（黒野式全身調整基本穴） と症状に随つた局所療法に基づいた銊治療を行っ た。治療期間：平成10年7月 14 日から平成 14 年 11月27日までの1598日間（991回）。治療頻度： 毎日とした。評価方法 : 不定愁訴カルテ、血中ア ンモニア值、出血時間、プロトロンビンについて 観察した。

【結果】初診時の不定愁訴指数 51 点が 3 点に、血 中アンモニア值は240〜300 $\mu \mathrm{g} / \mathrm{dl}$ が110〜160 $\mu \mathrm{g} / \mathrm{dl}$ 程度で推移し、出血時間は正常範囲となり、 プロトロンビンに関しても正常值を示している。

【考察】鍼治療を施すことにより、免疫機能や再 生機能が賦活され、血中アンモニア值、出血時間、 プロトロンビン濃度などがほぼ正常範囲となり、 不定愁訴指数 51 点が 3 点と低下を示し、QOLの 改善が確認できたことなどにより肝臓機能が回復 しつつあると思われる。

【結語】今まで、肝硬変症に対して有効な治療法 がないとされてきたが、今回の非代償性肝硬変症 に対する銊治療により部分的かつ僅かではあるが 治癒の方向に向かっていることが示唆された。

キーワード : 肝硬変症、腹水、肝性脳症、血中ア ンモニア值、黒野式全身調整基本穴 


\section{0-C-15:00 \\ 脱毛を主訴とし、夜尿症、気管支喘息 及びアトピー性皮膚炎を合併した小 児患者に対する鍼治療の1例}

明治鍼尒大学老年鍼众医学教室

明治鍼众大学臨床鍼尒医学 II 教室

明治鍼众大学健康鍼众医学教室

明治鍼尒大学内科学教室苗村健治、山村義治

【目的】脱毛を主訴とし、夜尿症、気管支喘息及 びアトピー性皮膚炎を合併した小児患者に鍼治療 が有効であった1例を報告する。

【症例】15歳男性。5歳頃から脱毛が始まり、近 医を受診するも原因不明であった。夜尿症は乳児 期から継続し、中学校入学頃より悪化した。気管 支喘息とアトピー性皮膚炎は3歳頃から認められ た。いずれの疾患に対しても他に治療を受けてい なかった。

【所見】(1)脱毛は、前頭部から頭頂部にかけて認 められ、頭頂部から後頭部には散在性にうぶ毛様 の発毛がみられた。(2)夜尿症は、自宅では週に3 〜4回認められたが、外泊時等には夜尿はなく、 心因性の関与も考えられた。(3)気管支喘息は、初 診時には、自覚・他覚的症状共に認められなかつ たが、季節の変わり目に喘息発作がよく認められ た。(4)アトピー性皮膚炎は、全身に皮膚の乾燥を 認め、後頝部と时窩部に強く、軽度の紅斑がみら れた。熱感、法出液、丘疹、掻破痕は認めなかっ た。掻㾕は後頝部と时部に認められたが、日常生 活が障害されるほどではなかった。

【治療方法】東洋医学的所見により腎精不足証、 血虚証と弁証し、証に基づいて治療した。脱毛に 対しては時に閻三針を行った。鍼治療は週 1 回、 36週に35回行った。

【結果】治療25回（5ケ月後）には、後頭部から 頭頂部にかけて毛髪は明らかに増加した。夜尿症 は「1ヶ月に1〜2回」にまで改善した。気管支喘息 やアトピー性皮膚炎は、「前年の同時期よりも症 状悪化の程度が少ない」との患者のコメントが得 られた。アレルギーの状態を示す末梢血好酸球数 は $22.9 \% \rightarrow 18.4 \%$ 、血中 IgE RIST值は $304 \mathrm{IU} / \mathrm{ml}$ $\rightarrow 222 \mathrm{IU} / \mathrm{ml}$ と低下した。

【考察と結語】脱毛、夜尿症、気管支喘息、アト ピー性皮膚炎を合併した1例に対し、東洋医学的 な観点から全身的に診断と治療を行い、症状の改 善が得られた。東洋医学的な治療方法が生かされ た症例であったと考えられた。

キーワード : 脱毛、夜尿症、気管支喘息、アトピー 性皮膚炎、鍼

\section{$20-C-15: 12$ \\ アトピー性皮膚炎の鍼炎治療と自己 免疫疾患への応用}

一表記疾病治療と予防を目的とするEBM評価作業一

東京地方会

飯沼浩江

国立塩原視力障害センター

宮腰 治

【目的】本学会で1988年より表題に関して毎回 発表してきた結果、幼児のアトピー性皮膚炎及び 気管支喘息は全例治癒し、成人の（特異・非特異） IgE 高値者や長期ステロイド使用者、SLE、潰瘍 性大腸炎等の自己免疫疾患罹患者、抗核抗体検出 者、肝・腎臓同時悪化を血液検査で確認した表題 疾病罹患者等の治癒への道程をそれぞれの切口で 発表してきた。旧文部省児童健康調査でアレルギー 関与の疾病は増加している、この状況に答える為 に幼児・児童のアレルギー疾病を早期治癒に至ら せ健康に育てる治療手段として当該治療結果の精 査の緒についたが、今回も引き続き報告し併せて $\mathrm{EBM}$ 評価作業への道程とした。

【対象者・治療方法】 (I) 幼児・览童で当該治療 を受けた患者群の、家族からの自筆自主記載方式 での結果を集計する。(II) 免疫抑制薬使用による 局所リンパ節腫脹と全身性皮膚炎症へ移行した患 者2名。《治療方法》1) 30mm14号ディスポ針で 数力所の接触針、中級もぐさ少量を 5 秒 30 秒連 続燃焼 $38^{\circ} \mathrm{C}$ 以下で熱感を与えない。2)皮膚温度 の精製水洗浄。3) 植物多品目入りスープの飲用。 《記録方法》1) 経過写真。2) IgE、好酸球、LDH、 CH50、抗核抗体、炎症反応、肝 - 腎機能検査。 3) 成長記録。

【結果】1)長期・多量ステロイド塗布箇所に限 定した島状の皮膚炎悪化は、当該治療で前回発表 後4例増加、合計112例（男性42例、女性60例） 全例治癒。2)対象者 (I) は健康状況向上が具体的 に見えた。（II）は7ヶ月間の治療で治癒したと判 断したが、プロトピック軟亮（免疫抑制薬）塗布 局所のみ突然再発症した。3ケ月間の当該治療で 皮膚症状は安定している。

【考察、結語】当該治療はアレルギ一疾病を治癒 し、克つ健康増進作用があると証明できる。行政 が研究着手している I 型アレルギー遺伝子探査は 治らない理由づけや、優性学につながる危険があ る。今、アトピー性皮膚炎の治療に免疫抑制薬使 用の安易な判断があり、本研究は未来への禍根を 断つ目的もある。

キーワード：アトピー性皮膚炎、ステロイド離脱、 プロトピック軟膏、鍼尒治療 


\section{0-C-15:24 \\ 皮脂欠乏症に対する鍼治療効果の一 考察}

一未梢血液像の変化一

筑波技術短期大学鍼众学科

和久田哲司、柴崎正修

【目的】皮脂欠乏症に対して鍼治療を 2 年余り行つ てきたところ、一定の治療成績が得られた。そこ で、鍼治療の作用機序を確認する一方法として、 治療効果の観察とともに白血球系の血液像の変化 を観察して、鍼刺激が惹起する影響について考察 した。

【方法】皮脂欠乏症、64歳、男、技師。9 10年前 より本症を発症。2000年3月に本学診療所を受診。 初診時には背腰部から足指に至る下肢全体の強度 の掻痒と枯燥が見られた。

鍼治療: '00年6月より開始し、全身状態の改善の ため難経に基づく本治と腹部刺鍼。局所刺銊は 患部の数穴に置鍼し副刺激法を加えた。治療後 に円皮鍼をほぼ6ヶ所に添付した。

観察：治療成績は「掻痒・枯燥自覚評価表」（自作） を作成し症状の推移を改善率で評価した。（身 体を15区分し、それぞれに掻痒・枯燥の強度を 2 〜0点に分け合計点が大きいと重症となる)。 血液像は、初診時（'00年3月、評価点16、改善率 $0 \%$ ）、比較的改善時第 10 診（'00年9月、評価点 5、改善率69\%)、第43診再発傾向時（'01年7 月、評価点7、改善率 $51 \%$ ) 及び完治第74診('02 年 8 月、評価点0点、改善率100\%) を検討した。

【結果】(1)初診時に単球が正常值より高值にあっ たもの、またリンパ球が低值であったものが、共に 正常值に復した。(2)好酸球は高值であったものが 完治状態には正常値に復元した。(3)好塩基球は初 診時正常值上限にあったものが、比較的改善時に は半減した。(4)好中球は正常值にあったものが完 治状態でやや高值を示した。

【考察】(1)単球及びリンパ球が症状軽減に付随し て正常值に復元したことは免疫能が高まったもの と推測される。(2)好酸球の復元はアレルギー性炎 症が改善したものと思われる。(3)好中球の変化は 防衛の向上の現れと思われる。(4)生化学検査にお いても微妙な変化が見られるため、更なる血液像 の影響とともに検討が必要である。

キーワード：皮脂欠乏症、白血球、血液像、鍼治 療、掻痒・枯燥評価表

\section{0-C-15:36}

関節リウマチ患者の頚部痛に対する 鍼治療

明治鍼众大学整形外科学教室

鷹峰澄子、小嶋晃義、北條達也、勝見泰和 明治鍼尒大学臨床鍼尒医学 II 教室

伊藤和憲、越智秀樹、北小路博司

【目的】関節リウマチ（RA）による環軸関節亜 脱臼は頝部痛を引き起こすことが多く、これらの 症状は、RA患者のQOL低下をまねく一因となつ ている。そこで、今回、環軸関節亜脱臼による頝 部痛を訴えるRA患者に対して鍼治療を行い、痛 みとQOLを指標として鍼治療の有用性を検討し た。

【対象】RA専門外来に通院中の頝部症状を訴え るRA患者5例。X線動態撮影所見より環椎歯突起 間距離（以下ADI）は $4 \mathrm{~mm}$ 以上であった。頝部 症状は後頭部痛、頚部痛、頝肩部痛であった。 Larsen 分類grade $3 \sim 4$ 。 class分類2３であった。 神経症状は 1 名に出現していた。

【方法】治療は $1 \sim 2$ 週間に 1 回の頻度で $2 \sim 3$ ケ月 間行つた。治療終了時から 3 ケ月後を経過観察期 間とした。治療部位は山本らが作成した「頝部関 節リウマチ病期別治療チャート」に基づいて、風 池穴、天柱穴、肩井穴などに行った。さらに治療 期間中は全身状態と治療前後の頝部痛をVAS (visual analogue scale;VAS) で評価した。QOL、 RA活動性は治療開始時、治療終了時、経過観察 終了時の合計3回調査した。QOLは旧厚生省リウ マチ研究班の作成したAIMS-2 日本語版調查票を 用いて調査した。

【結果】5例中3例は、ADI5mm以下で軽度の患 者であり、鍼尒治療によって頝部痛の直後効果が みられ、QOLも全身状態と共に改善傾向を示す 項目が多く見られた。しかし、2例は、ADI8mm 以上と重度の患者であり、治療回数を重ねても改 善はあまり見られなかった。

【考察】環軸関節覀脱臼による頝部痛に対しては、 有効な保存療法は確立されていない。そこで、今 回、鍼治療を行ったところ、ADIが軽度の患者で は、良好な結果を得ることができた。しかし、 ADIが重度の患者では効果が見られなかった。よつ て、RA患者の環軸関節亜脱臼による頝部痛に対 する鍼治療は、適応期を考慮したうえで行うと有 効であると考えた。

キーワード：関節リウマチ、頝部痛、QOL、銊 治療 


\section{0-C-15:48 \\ 喘息症状が炎療によって改善された と思われる55才男性の 1 治験例}

愛媛県立中央病院東洋医学研究所

上拫樹夫、光藤英彦

【目的】気管支喘息は伝承東洋医術の比較的ポピュ ラーな適応対象であり、光藤の師匠達の豊かな治 験報告が残されている。このような治験の結果と して発見された喘息俞と命名された穴位がある。 山本、深谷はそれぞれ別個に背中のTh6 棘突起 両側に位置する喘息俞の治効を確認した。私の担 当した一事例は病症が気管支喘息であり、この両 先生の指摘する穴位に特徵あるSignが穴位に認 められたのでこれらを含む穴位治療を施術したと ころ主病に対して有効であったと判断されたので 報告する。

【症例】55才、男性、主病症は “気管支喘息” (2次的病症は味覚障害)、副病症は偏頭痛、肩凝 り、耳鳴り、高血圧。〔現病歴〕H11年4月（53 才時）勤務先が障害者施設に、移動となる。母親 （D M、直腸ガン）死去。54才時2ヶ月間ほこり の多い倉庫の整理をしたり、又夏にクーラーが入っ てから喘息症状（咳、痰、のどがヒューヒューい う）発症。喘息の薬（テオドール、オノン）の副 作用か分からないが、味覚障害になったと云う。 〔穴位治療〕施尒指導は、手足三里、陶道、霊台、 喘息俞。刺絡は、後頭部充血部位、或中、俞府。 （医師の指示により処置を行う）众頭針は陶道、

霊台、腎俞付近。〔経過〕1クール終了時（1Wに 1回で6回の通院）の喘息症状に対する評価はA 評価（良くなっている）であった。

\section{【考察と結語】}

主病症に対する効果への考察 : 光藤の師伝であ る众療と刺絡法は共にその適応の所見があり運用 したがこの事例の有用性に寄与していると判断さ れた。主病症以外の病症CHP (Cronic Health Problems）の効果に対する考察：味覚障害及び 偏頭痛に対してはいずれの穴が有効に寄与したの かは判断できない。

キーワード：喘息、お众、喘息俞

\section{0-F-14:00 \\ 肺癌の化学療法による副作用に対し て鍼治療が有効であった 1 症例}

明治鍼众大学内科学教室

植松佑介、山村義治、苗村健治

明治鍼尒大学老年鍼众医学教室

江川雅人

明治鍼众大学健康鍼众医学教室

矢野 忠

【緒言】我々は肺癌の 1 症例において、化学療法 の副作用による症状の抑制を目的として鍼治療を 行ったので報告する。

【症例】65歳、男性。(1) 診断名: 肺扁平上皮癌 術後再発、（2）主訴：化学療法中の全身倦总感、 頭痛、嘔気、（3) 病歴：2001年7月に肺扁平上皮 癌に対する右肺上葉切除術が施行されたが、同年 11月に肺内転移による再発が確認され、点滴に よる化学療法 (CDDP 130mg (day1) + MMC 13 mg (day1) +VDS 5 mg (day 1,8)) が開始され た。化学療法による、全身倦急感、頭痛、嘔気など の副作用の症状に対して鍼治療を開始した。化学 療法は1クール約30日間の計9クール施行された。

【所見及び病態】全身倦怠感は日内変動なく、常 に認められた。頭痛は頭部全体が締め付けられる ような重だるい痛み、嘔気は制吐薬でも改善しな かった。胸部X線CTにて $1.0 〜 1.5 \mathrm{~cm}$ 大の腫瘍影 が数ヶ所認められた。中医学的には脾胃湿熱証と 肝稣気滞証と弁証した。

【治療 - 効果判定方法】治療は健脾と利湿、疏肝 理気を目的として百会、内関、足三里、太衝、内 庭、豊隆、陰陵泉、脾俞を基本穴とし、置鍼術 10 分間を行った。治療頻度は化学療法の各クー ルの入院期間中、土日を除く毎日行った。全身倦 忞感、頭痛、嘔気についてはVisual Analogue Scale（VAS）法、気分も含めた全身的な体調に ついてはフェイススケールにより評価した。

【結果とまとめ】化学療法9クールの入院治療中、 合計207日間に89回の鍼治療を行つた。鍼治療の 効果は、短期的には鍼治療直後で各症状の軽減が 認められた。また、観察期間の前半4クールでは、 銊治療による各症状の改善は緩やかであったが、 後半の5クールでは、鍼治療により、比較的速や かな改善がみられた。これは、鍼治療の継続によ る長期的効果と考えられた。また、副作用の症状 が軽減され、9クールという長期間に渡り化学療 法を継続することができ、胸部X線、CTにおい て、腫瘍の縮小が確認された。鍼治療が副作用に よる症状の抑制を目的とし、癌治療における補完 医療として位置づけられるものと考えられた。

キーワード : 肺癌、鍼治療、化学療法、副作用 


\section{0-F-14:12}

\section{不定愁訴に対する鍼治療の 1 症例 \\ 一大腸癌手術後に生じた不定愁訴一}

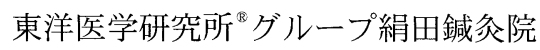

絹田 章

【目的】近年、わが国において食生活が欧米化し、 生活習慣病ともいわれている大腸癌に罹患する人 が増加している。今回、大腸癌の手術を受け、種々 不定愁訴を訴えて来院した患者に対して鍼治療を 施し、症状の推移を客観的に検討する目的で（社） 全日本銊尒学会研究部不定愁訴班作成の不定愁訴 カルテを使用して鍼治療の有効性を検討したとこ ろ、1 例ではあるが興味ある結果が得られたので 報告する。

【症例】患者：男性、69歳。現病歴：平成11年4 月8日に大腸癌の手術。その後排便過多（1日4〜 5回）に悩み、いつ便意をもよおすか不安になり、 頭痛、肩こり、たまに手足がしびれるなど種々の 不定愁訴を発症。現症 : 脉状診; 浮・滑、脉差診 ; 肝虚証、血圧 ; 146/86mmHg、脈拍；66回/分、 腹診 ; やや軟、背診; 項背強、身長 ; $162 \mathrm{~cm}$ 、 体重；69.3kg、BMI；26.4、不定愁訴指数；26 点（重症度判定中等症）。治療方法：随証療法 (曲泉、太衝)、太極療法（黒野式全身調整基本穴）、 局所療法（合谷）で $30 \mathrm{~mm} 18$ 号鍼を用い、単刺術。 評価法 : 不定愁訴力ルテ。治療期間 : 平成 12 年 4 月 13 日〜平成 12 年6月 26 日まで 75 日間 (14回)。

【結果】下痢便で 1 日 $4 \sim 5$ 回の排便が正常便で 1 日2回に改善、頭痛は消失、肩こり及び手足のし びれは軽減。初診時不定愁訴指数 26 点（中等症） が、次回来院時 26 点、8回目来院時 11 点、 15 回 目来院時（最終時）では7点となり、不定愁訴指 数減少率 $73 \%$ で効果判定は著効。

【考察】鍼治療による種々の不定愁訴の改善に伴 い、大腸癌手術後の排便過多についても通常の経 過より早期に改善がみられたと考える。

【結語】大腸癌手術後に生じた不定愁訴に対して 14回の鍼治療を施し、不定愁訴カルテにより検 討したところ、鍼治療の有効性が客観的に証明さ れた。また、大腸癌手術後の機能障害と思われる 排便過多も改善され、鍼治療が手術後のケアとし て有用である可能性が示唆された。

キーワード：生活習慣病、大腸癌、機能障害、不 定愁訴、太極療法

\section{0-F-14:24 \\ 手術後の健康障害· 再発不安の解消之 QOL障害の改善に有用であった 2 症例}

愛媛県立中央病院東洋医学研究所

村山 功、山岡傳一郎

【はじめに】私どもの研究所では時系列分析法を 用いて、炎療を中心とした診療を続けている。今 回、子宮がん手術後および胃がん手術後の健康障 害の改善と再発不安の解消とともに、QOL障害 の改善に役立つたと思われる症例を得たので報告 する。

【症例】症例 $1: 69$ 才の女性。平成 12 年 10 月、 子宮および付属器の全摘手術を受ける。その後腹 部の痛みが続き再発・転移の不安が募り、睡眠不 良となる。術後の体質改善、免疫力の向上を希望し て当研究所を受診。鍼众治療は沢田流太極療法に 則り、炎点として曲池・足三里・三陰交・百会・ 身柱・天髎・膈俞・腎俞等の要穴を取穴、自宅施 众を指示。経過はアンケート方式の患者自己評価 では、すべての項目で自覚症状の改善と不安感の 解消が認められ、QOLの向上に役立つたと思わ れる。

症例 $2: 62$ 才の女性。平成 11 年 1 月胃ガンの摘出 手術を受ける。その後肝機能障害を指摘され、胃 痛・食欲不振・易疲労などの健康障害を発症。家 族歴にもガンの人がいて再発不安をかかえ当研究 所を受診。銊众治療は前症例と同様に沢田流太極 療法に則り、炎点として曲池・足三里・附分・至 陽・肝俞・脾俞・腎郁等の要穴を取穴、自宅施尒 を指示。経過は順調で同前の評価法でも満足度は 高く、QOL障害の改善に役立つたと思われる。

【考察および結語】時系列分析法にはチーム医療 を行うスタッフが患者の生活背景や家族状況がよ く理解できる利点があり、特に不安感を持つ患者 とのコミュニケーション上有用と思われる。また 私どもの研究所では家族間での众療を推奨してお り、家族による施尒で心の交流が図られ、苦痛の 軽減だけでなく精神的安定も得られたと推測する。 四国地方はお众発祥の地であり、21世紀に向け てその文化の継承・発展のために、私ぎもの研究 所に課せられた責務は大きいと思われる。

キーワード：時系列分析、自宅施尒、QOL障害 


\section{0-F-14:36}

\section{当科における悪性腫瘍患者に対する 鍼炎臨床の実態分析（第2報）}

埼玉医科大学東洋医学科

廣瀬賢一、山口 智、小俣 浩、新井千枝子

阿部洋二郎、浅香 隆、大野修嗣、藤岡正志 埼玉医科大学健康管理センター 土肥 豊

【目的】我々は、第51回本学会において当科で 取り扱つた悪性腫瘍患者の訴える疼痛や愁訴に対 する鍼治療の実態を分析した結果、銊治療は現代 医療に併療する治療法として、有用性の高いこと がわかった。そこで今回は、さらに症例を追加し、 鍼治療効果と患者の背景因子との関係についても 検討した。

【方法】対象は、過去5年間に当科を受診した悪 性腫瘍患者19例（男性10例・女性9例、9歳～82 歳、平均年齢57.5歳 \pm 17.7 歳 mean \pm S.D.) であ る。方法は、依頼診療科、入院・外来の別、基礎 疾患及び合併疾患、鍼治療の対象となった症状、 罹病期間、鍼治療期間と治療回数、鍼治療成績に ついて検討し、鍼治療効果率と背景因子との関係 について分析した。

【結果】(1)依頼診療科は、内科からの依頼が7割 を占め、基礎疾患は肝臓癌や前立腺癌、合併疾患 は腫瘍の原発巣に伴う疾患、治療方法では化学療 法と放射線療法の併用が多く、薬物療法は鎮痛剂 及び鎮痛補助薬が投与されていた。これら患者群 の症状は腰痛が最も多く、下肢痛・胸痛・背部痛・ 顔面筋麻痺と続き、鍼治療期間・回数は 1 日 738日 (平均132.6日 日186.5)、1回から92回 (平 均22.8回土22.2) であり、鍼治療成績は有効・や や有効を併せて $75.6 \%$ 有効率であった。(2)鍼治 療効果率と背景因子との関係では、基礎疾患が肝 臓癌で合併疾患に癌転移を有する患者群の効果率 が高く、罹病期間は 1 年以上で鍼治療回数が 20 回 以上の患者群で効果率が比較的高い傾向が認めら れた。

【考察および結語】以上の結果より、原発巣のも つ要因や転移の有無、罹病期間、鍼治療回数等が 鍼治療効果率に影響を及ぼしている可能性が考え られた。これらのことから、悪性腫瘍患者に対す る鍼治療は、患者の背景因子を詳細に分析し、適 応や限界を検討することが臨床上極めて重要であ ることが示唆された。

キーワード：悪性腫瘍、癌性疼痛、鍼治療

\section{$20-\mathrm{F}-14: 48$ \\ 緩和ケア病棟における電子温炎器の 応用 (第2報)}

東海大学医学部附属大磯病院銊尒治療室

川崎市立井田病院かわさき総合ケアセンター

高士将典

【はじめに】第20回全日本鍼尒学会関東甲信越 支部学術集会にて、緩和ケア病棟における電子温 众器を用いた治療（以下温尒という）の成績を報 告した。今回は評価判定の改良を試み、00年度 31 症例も加えて報告する。

【対象】 99年6月〜01年3月までに入院した癌患 者74例、平均年齢63.9歳、男性36例女性38例、 温众治療期間は平均 14.3 日であった。

【方法】治療は電子温众器（カナケン社製）を用 い経穴に温熱刺激を与えた。配穴は弁証に基づき 行つた。その指示を受け看護師が 1 日に 1 ～3回施 行した。評価判定は、主訴の長期評価（治療開始・ 終了時期に0〜 5のフェイススケールで聴取、2段 階以上改善を 2 点、1段階の改善を 1 点、変化なし を 0 点、1段階以上の悪化を-1点とした）と主訴 の直後評価（治療直前後で、上記と同様の評価） と看護記録からの患者印象度（1点、0点、-1点）、 以上の 3 つの評価を合計して、4点以上を著効、 2 〜3点を有効、1 - 1 点を不変、 -2 点以下を悪化と 判定した。また聴取できないのを不明とした。

【結果】著効が $17.6 \%$ 、有効 $33.9 \%$ 、不変 $40.5 \%$ 、 悪化 $5.4 \%$ 、不明 $2.7 \%$ であた。痛みを訴える症 例は、 58 症例と多く、有効以上が $55.2 \%$ あっった。 00 年度の症例は温众開始の時期が早くなり、有 効症例数も増加した。また看護記録からリラック スしていることが伺われた。

【考察】緩和ケアチームが容易に参加できる温众 を行ってきた。そのため00年度になって、治療 時期の早期化や有効症例数の増加が見られた。こ れは無作為に治療を行うのではなく、治療時期と 対象患者の選択が向上した為と考えられる。また 患者にリラックスを与え、癒しにも貢献できた。 また増悪した症例から治療に適さない状態がある ことがわかった。

【まとめ】温众はターミナルケアにおける代替医

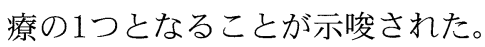

キーワード：代替医療、チーム医療、電子温尒器 治療、痛み、癒し 
20-F-15:00

両側慢性硬膜下血腫が消失した患者

一予後観察一

（社）全日本鍼众学会愛知地方会研究部頭鍼療法班 田中法一、田中喜浩、藤井良平、竹内昭夫

【目的】2002年の当学会第51回学術筑波大会で ポスター発表した症例（両側慢性硬膜下血腫が頭 鍼療法で改善した 1 症例）の予後経過観察を報告 する。

【方法】治療終了後の予後経過を1ヶ月に1〜2回 来院することとし、自・他覚所見及びMRI検査に より追及して行くことにした。

【経過観察】（1回目来院）平成 12 年 12 月 18 日 〜22日まで、12月のMRI検査では両側慢性硬膜 下血腫（以後血腫と略す）が消失していた。(2 回目来院）平成13年1月 20 日、1月のMRI検査で も血腫は消失していた。頝部MRI検査異常無しと 診断された。（3回目来院）平成14年7月 30 日〜8 月8日まで、所見は右上肢挙上 $90^{\circ}$ 、三角筋萎縮、 結髪障害陽性、手指末端に痺れ感があり、圧痛は 欠盆・天宗・膏肓・脾臑・鎖骨肩峰直下 ・雲門等 にあった。(4回目来院) 平成 14 年 8 月 28 日〜 30 日まで、今回は頭部・頚部のMRI検査結果のフイ ルムを借用し持参、血腫は完全に認められず神経 症状もない、（5回目来院）平成14年9月21日〜 27 日まで、頸肩腕の症状は徐々に六進している。 血圧は最高血圧（119～124mmHg）－最低血圧 (62〜 71mmHg) と正常值を保っている。

【結果】本症例の経過観察の結果、治療終了後、 MRI検査を 4 回受けた。血腫の消失に付いては平 成 12 年 12 月のMRI検査に異常なし、平成 14 年 8 月9日撮像のMRI検査で完全消失と診断された。

【考察・結語】MRI検査 (8月9日撮像) で血腫の 存在は完全に否定されたことになった。頭鍼療法 による脳内賦活が起きて脳内血流が活性し血腫を 溶解吸収したものと考える。長い月日をかけて存 在していた血腫が、鍼炎治療により脳内の異物や 腫瘤等吸収処理能力を活性化させる事が示唆され た。

キーワード：両側慢性硬膜下血腫、MRI検查、頭 鍼療法（焦順発）

\section{0-F-15: 12 \\ 脳梗塞後遺症に対し電気炎治療を試 みた 1 症例}

財務省東京病院東洋医学センター

豊田陽子、坂井友実、安野富美子

筑波技術短期大学鍼尒学科横川孝一

【目的】脳梗塞後遺症患者の上肢症状に対して、 電気众治療を行い良好な結果を得たので報告する。

【症例・方法】73歳、男性。主訴: 左上肢重苦 感、動かし難さ。現病歴:平成 12 年 1 月、両足の痺 れ感出現し、脳梗塞と診断され近医に2 月 平成 13 年 8 月、左上下肢の麻痺出現し、当院内科 入院。現症：身長 $165 \mathrm{~cm}$ 、体重 $62 \mathrm{~kg}$ 、血圧 136/84 mmHg、脈拍69拍/分、肩 ROM; 外転右 $180^{\circ}$ 、左 $120^{\circ}$ 、屈曲右 $180^{\circ}$ 、左 $120^{\circ}$ 、深 部反射; 上・下肢左六進、触覚;左前腕 6 領域鈍磨、 左三角筋の萎縮著明、左上肢の皮膚温低下、

Brunnstrom Stage; 上肢5、MRI;放線冠・視床・大 脳基底核に陳旧性梗塞あり。方法：電気尒はソフ コンMXA-8000（全医療器社製）を用いた。治 療穴は、左の合谷・手三里・曲池・手五里・臂臑・肩 髃・中府で、設定温度はM (47.5度)、刺激時間は 15分間とした。皮膚温の変化は、施術前、施術 中、施術終了15 分後までサーモグラフィ （THERMOVIEWER JTG-3570JOEL製）にて測 定した。また、経過を追って上肢皮膚温を測定し た。

【結果】施術前後の皮膚温変化は、施術終了6分 後より左上肢全体の皮膚温の上昇がみられ、15 分後では手背、前腕部の平均皮膚温度が、施術前 に比し、1.3度上昇し、術前に見られた左右差が 改善された。又自覚的には、術後約30分で左手 に力が入る感覚がみられた。第3診で、術前の皮 膚温の左右差が 2.3 度から 0.4 度に改善され、第 16 診後では重苦感も改善され自覚的に左手に力が入 るようになった。

【考察】電気众施術直後には皮膚温の著明な上昇 と自覚症状の軽減がみられ、治療継続とともに上 肢皮膚温の左右差もなくなり、症状も消失した。 このことから、電気众は脳梗塞後遺症の上肢症状 に対して症状を緩和させる可能性が示唆される。

キーワード : 電気尒、脳梗塞後遺症、皮膚温、サー モグラム 


\section{0-F-15:24 \\ 脳血管障害の片麻痺に伴う上肢浮腫 に対する炎療法の効果}

慶熙大学韓医学部附属韓方病院第 2 内科学教室

曺 基湖、鄭 宇相、崔 耀狺

慶山大学韓医学部鍼众学科

徐廷徹

明治鍼尒大学東洋医学基礎教室

明治鍼尒大学大学院鍼尒学研究科昭二、和过直

【目的】脳血管障害の症状として片麻痺とともに 同側の上肢に浮腫が 16 ～82\%の比率で現れる。 この上肢浮腫は長くなると関節の線維化、強直、 疼痛が続さ、麻痺治療を遅延させる。確実な治療 法はまだ見つかつていない。そこで、今回は脳血 管障害の片麻痺に伴う上肢浮腫に対する众療法の 効果について検討した。

【方法】 2001 年 5 月から 12 力月間、当韓方病院 入院患者の中で脳CTないし MRIで脳梗塞、脳出 血が確定診断され、発症日から2週間以上過ぎて、 上肢容積計（hand volumeter）を使い、患側の 手部容積が健側より 30cc以上増加した患者42名 を対象として乱数表を使つたランダム化比較試験 （RCT）を行い、众治療群20名、众非治療群 22 名に分けた。众非治療群は標準治療、尒治療群は 標準治療に众治療を加え、施众は合谷、曲池、中 渚、外関に直接众 5 壮（米粒大、韓国江華産艾葉） を毎日、1回施行し、治療に係わっていない第三 者がhand volumeterで上肢浮腫容積を、巻尺で 第2指の太さ (Index Finger Circumference)、 運動指数（Motricityindex）を2週後にそれぞれ 測定した。統計学的な検定はchi-squaretest、 Mann-Whitney U testを用いた。

【結果】上肢浮腫容積の変化を観察したところ、 治療前後の比較で食治療群は2 $1.5 \pm 12.3$ (cc) の

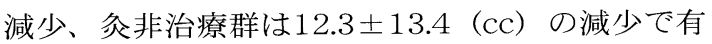
意な効果があった。第2指の太さでは、众治療群

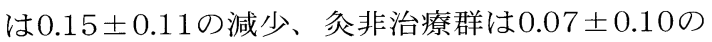
減少を示し、有意な効果があつた。運動指数でも、 众治療群は $16.5 \pm 9.0$ の増加、食非治療群は $8.0 \pm$ 6.5の増加で众治療の有意な効果が認められた。

【考察と結語】上肢浮腫の治療は、尒治療が浮腫 の減少だけではなく運動機能回復にも有意な効果 が認められたことから、食刺激による症状の変化 と血行の促進、組織の栄養状態改善、吸水機能の 活性が示唆された。

キーワード : 脳血管障害、片麻痺、浮腫、尒療法、 脳梗塞

\section{0-F-15:36 \\ 動作分析と東洋医学的観点から鍼治 療をおこなった書痙患者 2 症例}

谷浦クリニック ${ }^{1)}$

関西鍼尒短期大学神経病研究センター ${ }^{21}$

井上博紀 ${ }^{1,2)}$ 、谷万喜子 ${ }^{2)}$ 、高田あや2) 飯塚朋子 ${ }^{21}$

鍋田理恵 ${ }^{2}$ 、鈴木俊明 ${ }^{2)}$ 、若山育郎 ${ }^{2)}$ 、吉田宗平 ${ }^{2)}$

【目的】今回、ジストニアの一つである書痤患者 2症例に対して、動作分析と東洋医学的観点から 鍼治療を行い、その効果を書字評価テスト、自覚 的評価から検討した。

【症例】症例 $1 ： 67$ 歳、男性。平成8年頃より書 字動作に困難を認め、平成14年6月27日に本学附 属診療所神経内科を鍼治療目的で受診した。

症例 $2: 67$ 歳、女性。平成 5 年追突事故で右肩を 強打してから書瘥を発症した。西洋医学的治療で は改善が認められなかったため、平成14年8月 29 日に本学附属診療所神経内科を受診し鍼治療開始 となった。

2症例ともに、鍼治療前後での書字評価テストを 実施した。書字評価テストの内容は、1）「1〜 5」 までの数字、2）あ行のひらがな、3） あ行のカ タカナ、3）4重の螺旋点線上をなぞるテストと した。また、毎回治療後に書字動作の自覚的評価 （最悪を 10 点、正常を 0 点とする）を聴取し、検 討した。

【鍼治療とその結果】鍼治療は週1回おこなった。 2症例ともに、動作分析と東洋医学的観点から、 書字動作の円滑化を目的に書字をおこなう上肢と 対側の上肢区、不随意運動の軽減を目的に同側の 風池穴、腕神経叢へのアプローチとして気舎穴に 置鍼を行った。また、症例 2 に、、皮膚・筋短縮 および知覚・感覚入力の改善を目的に手掌部に集 毛鍼により刺激を加えた。鍼治療効果として、症 例1は銊治療開始3回目、症例2は5回目で書字評 価テスト、自覚的評価に著明な改善を認めた。

【まとめ】我々は頸部ジストニアに対して動作分 析と東洋医学的観点から鍼治療をおこない $75 \%$ 程度の改善を認めている。今回の書病も頸部ジス トニアと同様にジストニアの一種である。そこで、 今回の 2 症例に対して動作分析と東洋医学的観点 から鍼治療をおこない短期間で改善した。本研究 で用いた銊治療は、書痤に対する有効な治療法の ひとつであることが示唆された。

キーワード：書病、動作分析、東洋医学的観点、 銊治療 


\section{0-F-15: 48}

\section{頸部·体幹への総合的なアプローチが 必要であった頸部左側屈偏倚を主症 状とする頸部ジストニア患者への動 作分析と鍼治療}

関西鍼众短期大学神経病研究センター

飯塚朋子、谷万喜子、高田あや、井上博紀 鍋田理恵、鈴木俊明 若山育郎、吉田宗平

【目的】詳細な動作分析により体幹にも問題があっ た頸部左側屈偏倚を呈する頸部ジストニア患者 1 症例の銊治療について報告する。

【症例】症例は68歳男性である。平成7年に頸部 ジストニアを発症し、平成13年8月23日、銊治療 目的にて関西鍼尒短期大学附属診療所神経内科に 来院した。初診時の頸部姿勢は左側屈、屈曲、肩 甲帯左挙上でTsuiスコア14点であった。表面筋 電図評価に基づき循経取穴を基本とした鍼治療を 行った。9カ月後にはTsuiスコア8点に改善した が主な偏倚である頸部左側屈は改善せず、立位、 歩行では増悪した。そこで、立位、歩行における 頸部肢位の変化に関する動作分析が必要と考えた。

【立位、歩行の動作分析】安静立位では頸部左側 屈、肩甲帯左挙上だけでなく、著明な体幹右側屈 を認めた。これは、頸部左側屈によって左に偏る 重心を中心に保つための代償であると考えた。歩 行の右立脚期では、立位と同様に代償としての体 幹右側屈を認めた。また、歩行時に頸部を随意的 に正中位保持することは可能となったが、肩甲帯 左挙上および体幹右側屈が著明であった。この結 果、本症例は頸部に対する銊治療だけでは肩甲帯・ 体幹偏倚が改善しないことがわかり、頸部・肩甲 帯・体幹に総合的にアプローチする必要性を認め た。

【鍼治療】今まで行っていた頸部左側屈の原因で ある左側頸部皮膚短縮に対する散鍼、左僧帽筋上 部線維の筋活動六進に対する左外関への置鍼に加 えて、体幹右側屈の原因である右腹筋群の筋緊張 低下に対して衝陽に置鍼した。また、鍼治療中に 座位・立位での側方移動を行わせ、動作時に頸部 ・ 体幹偏倚が軽減することを確認した。

【結果および結語】未だ頸部・体幹に偏倚を認め るものの、立位・歩行での偏倚の程度は軽減した。 頸部側屈偏倚を認める頸部ジストニア患者に対し ての臨床症状評価は頸部だけでなく体幹も考慮し、 安静時および動作時に評価する必要性が示唆され た。

キーワード：頸部ジストニア、動作分析、鍼治療

\section{P-D-09:00 \\ 肝焱ウィルスの鍼体への付着性につ いて}

関西鍼众短期大学免疫・病理学教室

大市三鈴、松尾貴子、笠原由紀、栗林恒一 関西鍼众短期大学鍼众学基礎教室

楳田高士

【目的】肝炎ウィルス感染者に対し鍼治療を行つ た際、抜鍼後の鍼体に付着したウィルスにより鍼 食師の手指が污染される可能性がある。このよう なウィルスの鍼体への付着が、刺鍼部位を綿花で 押さえながら抜銊するという操作によりどの程度 防ぎ得るかを検討するため、今回はまず、ウィル スを含んだ血清を鍼体に直接塗布し、それを綿花 で拭うことにより、付着させたウィルスが除去で きるか否かについてPCR法を用いて検索した。

【方法】HCV抗体陽性者3名、HBs抗原陽性者3 名より血清を採取し、それぞれについてPCR法 によりウィルス遺伝子の検出を行なった。それに より、これらの血清の中からもっともウィルス量 の多い血清を選択し、それに鍼を浸漬して鍼体に ウィルスを付着させた。これらをエタノール綿花 もしくは乾綿にて拭い、その後の鍼体に残存した ウィルス遺伝子を検出した。HCVの検出は、 $\mathrm{HCV}$ 遺伝子のUT領域に対する primerを用いて nested PCR法により行つた。また、HBVについ ても同様に、S抗原遺伝子の領域に対する primer を用いたnested PCR法により検出した。

【結果】いずれのウィルスについても、同じ塗布 実験を2回繰り返したが、HCVに関しては、一度 目の実験では、エ夕ノール綿花で拭つたものも乾 綿で拭ったものもいずれもウィルス遺伝子を検出 しなかつたが、二度目の実験ではエ夕ノール綿花 で拭つた鍼体から HCV遺伝子の残存が検出され た。HBVについても同様に実験を2回繰り返した が、どちらの実験においてもエタノール綿花で拭つ た鍼体と乾綿で拭つた鍼体の両方からHBV遺伝 子が検出された。

【考察】抜鍼時に刺入部位を綿花で押さえるとい う操作は、ウィルス量がそれほど多くない場合に は、鍼体に付着したウィルスを除去するという点 である程度効果が認められる可能性が推察された。 現在さらに、実際に肝炎ウィルス感染者に対して 刺鍼した鍼体に、肝炎ウィルスがぞの程度残存し ているかについても検索を行っている。

キーワード : HBV、HCV、nested-PCR 
2P-D-09: 14

\section{鍼炎治療における感染防止について}

一手指の細菌污染亡感染防止対策一

関西鍼众短期大学鍼尒学基礎教室

楳田高士、宮崎浩一、山崎寿也、吉備 登 北村 智、錦織綾彦

【目的】近年、鍼众治療において、滅菌・消毒の 徹底が啓蒙され、感染に対する対策がなされつつ ある。しかし、2001年に行われた鍼众の安全性 の現状調査で「患者毎の手洗が徹底されていない、 交差感染の危険性がある」という報告がなされて いる。そこで、手指の付着細菌検査を行い、感染 防止について検討した。

【方法】本学教職員 14 名について、手洗い後、 臨床中、速乾性消毒剂（ウエルパス）使用直後に、 パームスタンプ培地を用いて細菌を採取、培養し た。さらに、手洗水の細菌検査、手洗石鹸（石鹸） および環境の細菌調査についても調査を行つた。 なお、手洗水の細菌検査はメンブレンフィルター 法を用い、環境の細菌についてはスタンプ法を用 いた。

【結果と考察】手指・手掌の平均コロニ一数（右 手：左手）は手洗い後 (263：255)、臨床中 (308：293)、速乾性消毒後（20：16）であった。 速乾性消毒剂の使用で付着細菌数が激減したが、 手洗後、臨床中には多数のコロニーが認められた。 手洗後に菌数が多く認められた理由については、 毛囊などに存在するレジデントフローラが手洗い により浮かび上がったためと考えられるが、手洗 水、石眯表面、蛇口ノブからも細菌を検出し、こ れらもその要因の一つであると考えられた。検出 した菌には日和見感染の原因菌として報告されて いるものも認められた。感染防止のためには、で きるだけ手の付着細菌数を減少させることが必要 である。今回の結果から、治療中の速乾性消毒剂 の使用は感染防止に有効であると考えられた。

【結語】手洗後および臨床中の手指・手掌に多く の細菌が認められた。手洗後の菌数を減少させる ためには、手洗い前に水をよく流す、液体薬用石 眯を使用する、手洗後にも速乾性消毒剂を使用す る等の対策が必要であり、臨床中の手指・手掌の 菌数を減少させるためには速乾性消毒剂の使用が 有効である。

キーワード：感染防止、手洗い、付着細菌、速乾 性消毒剂

\section{P-D-09:28 \\ 指サックが刺鍼手技に与える影響}

一継続的使用による痛みの変化一

筑波大学理療科教員養成施設

半田美香子、徳竹忠司、宮本俊和

【目的】鍼尒臨床における感染防止対策の一環と して、施術時の指サック等の使用が推奨されてい るが、日本国内の鍼治療施設においては、刺鍼操 作性の問題等から指サックが使用されていないこ とが多い。前回我々は、刺鍼操作中に被験者の感 じる痛みが指サック使用により変化するかどうか 検討した。その結果、指サック使用によって、痛 みの傾向に変化が生じることがわかつた。しかし、 前回の実験の施術者は日常の施術においては指サッ クを使用しない者であった。そこで今回、日常の 施術において指サックを使用し続けた施術者を対 象に、指サックを使用した刺銊操作時に生じる痛 みが使用しない刺鍼操作時の痛みの状態に近づく か、その学習効果について検討した。

【方法】施術者は、実験前まで日常の鍼治療で指 サックを使用しない鍼众師10名を対象とした。 対象となった施術者に実験開始から10週間後ま で、日常の臨床上で指サックを使用して刺銊操作 を行わせ、2週間ごとに10週まで評価を行った。 痛み程度と種類は、切皮時・刺入時についての (1) $100 \mathrm{~mm}$ VAS(2) 30種類の痛み用語によって、施 術者が被験者の腰部脊柱起立筋に左右一本ずつ刺 鍼を行う際に評価した。また、施術に所要した時 間を計測した。

【結果】痛み,施術時間とも指サックを継続的に 使用することによって、平均值では変化が見られ たが,統計学的有意差は認められなかった。痛み の質については相違が見られた。

【考察と結語】指サックの継続的使用によって、 各要素に若干の変化は見られたが、著しい学習効 果は認められなかった。今後、指サックを使用時 の刺銊手技等を検討する必要もあると思われる。

キーワード：感染対策、指サック、刺銊、VAS 


\section{P-D-09: 42 膏肓穴刺鍼の安全深度の検討（2）}

森ノ宮医療学園専門学校

尾崎朋文、佐藤正人、坂本豊次 川村病院小山田記念温泉病院

湯谷 達、米山 榮 徳島大学歯学部口腔解剖学第一講座 北村清一郎 大阪大学歯学部口腔解剖学第二講座 吉田 篤

【目的】前回、成人に対する検査ならびに遺体解 剖、CT画像から、亳肓穴刺鍼の安全深度を体型 別に報告した。今回はさらに被検査数を追加し、 膏肓穴刺鍼の安全深度を統計的に検討した。

【対象と方法】前回の成人104名での検查に、今 回さらに42名を追加し計146名を対象とした。方 法は、前回と同様に、伏臥位で肩関節を90度外 転し、左右いずれか一方で行った。鍼先が肋骨上 面に当たるように膏肓穴から頭尾方向に各 10 $\mathrm{mm}$ 以内の体表に刺入点を求め、体表に垂直に ディスポ鍼 $40 \mathrm{~mm} 18$ 号を刺入した。銊先が肋骨 上面に当たった時の、体表から出ている鍼体長を 計測し、この值から体表-肋骨間距離を求めた。 平均值の差は Mann-Whitney U-testを用い、有 意水準 $5 \%$ で検定した。

【結果】成人 146 例のBMI分類を用いた体型は、 男性 100 名では肥満型が25名、標準型が53名、 瘦せ型が 22 名であり、女性 46 名では肥満型が 12 名、標準型が 17 名、瘦せ型が 17 名であった。肥 満型、標準型、瘦せ型の体表-肋骨間距離の平均 值は、男性では各々 $24.7 \pm 4.5 \mathrm{~mm} 、 20.2 \pm 3.6 \mathrm{~mm}$ 、 $19.1 \pm 2.5 \mathrm{~mm}$ 、女性では各々 $20.8 \pm 3.2 \mathrm{~mm}$ 、 $17.9 \pm 2.9 \mathrm{~mm} 、 16.8 \pm 2.5 \mathrm{~mm}$ であり、膏肓穴へ の刺鍼時の安全深度の平均值は、前回発表したよ うに、これらの值に胁骨の厚みの $1 / 2$ である $5 \mathrm{~mm}$ を足した値とした。体表-肋骨間距離の平 均値と安全深度の平均值はいずれも、男女ともに、 肥満型は標準型および瘦せ型より有意に長く、標 準型と瘦せ型とでは差は認められなかった。また、 肥満型、標準型、瘦せ型の安全深度の最小值は、 男性では各々 $20 \mathrm{~mm} 、 19 \mathrm{~mm} 、 19 \mathrm{~mm}$ であり、女 性では各々 $21 \mathrm{~mm} 、 19 \mathrm{~mm} 、 18 \mathrm{~mm}$ であった。

【考察と結語】膏肓穴への刺鍼では、肋骨までの 距離および外傷性気胸に対する安全深度の平均値 は、男女ともに標準型と瘦せ型では差がないが、 肥満型が他の型より有意に大きく、肥満型ではよ り深くへの刺入が許される事を示している。しか し、安全深度の最小值をみると、肥満型と標準型 および瘦せ型とはそれほど差がないので、肥満型 患者への治療時でも注意が必要だと考えられる。

キーワード : 膏肓穴、安全深度、外傷性気胸、肋 骨、体型

\section{P-D-09: 56 \\ 鍼の安全性に対する鍼関連業者の見 解に関する国際アンケート調査}

筑波技術短期大学附属診療所

山下 仁、津嘉山洋

【目的】鍼の安全性についての鍼関連業者の考え を知るため、6ヶ国におけるアンケート調査を行っ た。

【方法】2000年9～10月に、日本、イギリス、 中国、韓国、ドイツ、アメリカの60の鍼メーカー および販売業者に、鍼の有害事象の知識、安全性 向上のための活動や意見などに関する質問紙を郵 送した。

【結果】回答したのは14業者で、国別の回答率 は日本64\%、イギリス $33 \%$ 、中国14\%、韓国 13 \%、ドイツとアメリカ $8 \%$ であった。有害事象で 興味が持たれていたのは感染 (5業者)、金属アレ ルギー（3）、折鍼(2) の順であった。製品に記 載している情報は使用期限 (10)、消毒・滅菌の 必要性 (10)、鍼の点検の必要性 (9)、専門家以外 の使用禁止（8）の順であった。8業者は可能性 のある有害事象について製品に記載して伝える必 要性があると答え、5業者は必要ないと答えた。 必要ない理由は「鍼の専門家はそのような情報は 当然知っておくべきだから」であった。社内外に おける安全性関連活動に対して7業者が投資して いた。

【考察と結語】鍼の安全性情報の普及に関して積 極的に役割を担うかどうかについては意見が分か れていた。鍼製品のパッケージへの印刷または添 付文書が、鍼治療家に情報を与える効果的な手段 のひとつであると我々は考えている。

(謝辞) 不躾な質問にもかかわらず丁寧に御回答 いただいた業者の方々、そして中国語版質問紙の 作成に御助力いただいた王財源、白錦棟、久下浩 史の諸先生方に心より感謝申し上げます。

（国際共同研究者）Jongbae Park、Adrian R White、 Edzard Ernst

キーワード：鍼、安全性、業者、アンケート、調 査 


\section{P-D-10: 10 学生の高齢者に対する意識調査につ いて（第2報）}

明治鍼尒大学東洋医学基礎教室

水沼国男

明治鍼尒大学老年鍼众医学教室

高橋則人、鶴 浩幸、江川雅人、松本 勅 特別養護老人ホームはぎの里＼cjkstart寺沢宗典

【目的】我々は、第50回大会において、学生の 高齢者に対する認識やイメージはマイナスのイメー ジが強く、老人ホームなどに訪問経験のある者の うちで、再度行きたいと考えている者は少なく、 実習の導入に当たつて意識づけが大切であること を報告した。そこで今回我々は、平成 12 年度 4 年 生を対象に老年ケア実習前後に高齢者のイメージ や認識等について調査しそれらの変化の有無につ いて検討した。

【方法】明治鍼众大学平成 12 年度 4 年生 計 118 名を対象に実習前後での学生の意識調査を行った。 実習開始前、実習終了後にアンケート調査を実施 した。調査内容は、高齢者のイメージ、介護保険、 高齢者への銊尒治療、特別養護老人ホーム等の施 設に関する項目等について調査した。高齢者のイ メージは、記述式を用い、その他の項目は、選択 肢からの選択法を用いた。

【結果】有効回答数は、実習開始時106名（有効 回答率 $89.8 \%$ )、実習終了時 56 名（有効回答率 47.5\%) であった。実習後、高齢者に接してみて、 「非常に楽しかった」「多少楽しかった」を合わせ ると70\%であったが、「これから高齢者に接した いか」では、「積極的に」が33\%、「仕事等で必 要があれば」が58\%であり、実習前と比べると 「積極的に」は39\%から33\%に減少し、「仕事等 で〜」は50\%から58\%に増加した。また、高齢 者のイメージが「変わつた」と考えた学生は、56 \%と半数を超えていた。さらに施設での鍼众治療 についてでは、「積極的に取り入れるべき」が55 \%、「可能な限り取り入れるべき」が $33 \%$ であつ た。また、就職先としては、「鍼众を主とする仕 事であれば」と考えている学生が半数を超え、 「介護」「鍼尒と介護の兼任」は約2割であった。

【まとめ】実習により高齢者に対する認識が高ま り、イメージが改善した者が多く見られたが、実 習終了後でも高齢者へのマイナスのイメージを抱 く者があり、これらを少なくするような働きかけ が必要であると考える。また、今回は実習後の回 収率が悪かつたが、今後回収率を高めるよう工夫 し、さらに検討したいと考える。

キーワード : 意識調査、実習教育、イメージ、高 齢者、鍼尒治療

\section{P-D-10:24}

\section{在宅ケアにおける鍼炎の役割}

財務省東京病院東洋医学センター

横川孝一、安野富美子

筑波技術短期大学銊尒学科

坂井友実

【目的】超高齢社会の現実化に伴い、脳卒中後遺 症や虚弱老人など介護を要する老人が増加し、在 宅ケアの需要も急増が予想される。今回、要介護 者およびその介護者に鍼炎治療を行う機会を得た ので、その概要を報告する。

【方法】対象は、平成14年4月から11月までの8 ケ月間に、在宅治療を依頼された要介護者とその 介護者とした。在宅ケアは(1)紹介を受ける(2)訪問 する(3)医師からの同意書をもらう(4)治療と評価を 行う(5)関係者へ報告するという手順で行つた。治 療は、週1～2回で1回30分程度とし、医療保険を 適用した。鍼尒治療は、局所への治療を中心に行 い、マッサージを併用した。

【結果】平成 14 年 11 月現在の患者内訳は、要介 護者16名（男性7名、女性9名）平均年齢は79.4 歳士7.7歳で、 60 代 1 名、 70 代 10 名、80代 3 名、 90 代2名であった。介護者は11名（男性1名、女 性10名）平均年齢は63.3土11.5歳で、50代5名、 60 代1名、70代4名、80代1名であった。介護度 は要支援が 1 名、介護度 1 が 3 名、 2 が 5 名、 3 が 5 名、5が2名であった。要介護者の診断病名は脳 梗塞後遺症 3 名、変形性膝関節症 3 名、パーキン ソン病 2 名、肺癌 2 名、閉塞性動脈硬化症 2 名等で、 愁訴としては膝痛6名、腰下肢痛 4 名、全身倦总 感4名、関節拘縮4名等であった。一方、介護者 の愁訴は腰痛 7 名、肩こり 6 名、疲労感 3 名であつ た。紹介者は、訪問看護師7件、ケアネージャー 1 件、医師 6 件、他 2 件であつた。尚、この8ヶ月 間で鍼治療の脱落例は 1 例もなかった。

【考察】今回取り扱つた患者は全例とも一度治療 を受けると治療継続を希望した。介護する側も高 齢であり、腰痛、肩こり、介護疲労などを抱えて おり、鍼尒やマッサージ治療が必要とされている ことが痛感された。このことは、鍼尒師の増加が 見込まれ、新たな職域開拓が必要とされる中、新 分野になる可能性が示唆された。

キーワード：在宅ケア、要介護者、医療保険、介 護者、鍼尒治療 


\section{P-D-10:38 老人保健施設における鍼炎治療（第1 報）}

明治鍼众大学老年鍼尒医学教室

高橋則人、江川雅人、鶴 浩幸、松本 栜 特別養護老人ホームはぎの里

寺沢宗典

【目的】我々は平成 13 年1月より、高齢者医療施 設の一つである老人保健施設においても鍼尒治療 を実施しているので、その治療実績について報告 する。

【方法】治療対象は、平成 13 年 1 月～平成 14 年 3 月までの期間で老人保健施設「はぎの里」に入所 中で、施設長（医師）より鍼众治療依頼のあった 入所者 18 名（年齢79.6 57.6 歳）であった。対象 者には痴呆性疾患を有する者はいなかつた。治療 は週に2回、専用の鍼众治療室にて行い、医師か ら依頼のあった愁訴に応じた治療を行った。治療 評価はそれぞれの愁訴にあわせ、ペインスケール や入所者の主観的な改善度を指標とした。

【結果】治療対象となった愁訴は、肩こりが7例 と最も多く、次いで腰痛 6 例、膝痛 4 例、臀部痛 およびリハビリ中の筋肉痛が3例で、疼痛が多く、 そのほかに半身不全麻痺2例などがあった。肩こ りではペインスケールが治療後に平均 $3.7 \pm 2.0$ と なり、症状の改善が認められた。またリハビリ中 の筋肉痛についても「リハビリ中の苦痛が軽減し た」ことを3例全てが認めた。しかしながら、半 身不全麻痺などに対しては、主観的な改善度も低 く、入所中の短期間の鍼众治療で改善を得ること はできなかった。

【考察】老人保健施設の入所者では、身体的な愁 訴が多く、肩こりなどの症状に対し、鍼众治療が 有効であることが示唆された。また半身不全麻痺 等に関しては、PTなどの他の医療スタッフとの 連携が必要で、長期的な治療を行わなければなら ないと考えられた。

【結語】老人保健施設での鍼尒治療により、入所 者の愁訴の一部が改善することが示唆された。ま たリハビリ中の苦痛を取り除くなどの効果もある ことが示された。

キーワード：高齢者、老人保健施設、銊尒治療、 肩こり、腰痛

\section{P-D-14:00 脈診訓練法の開発（第3報）}

日本鍼众理療専門学校 ${ }^{1)}$ 、(財) 東洋医学研究所 ${ }^{2)}$ 光澤 弘 ${ }^{1,2)}$ 、才戸正雄 ${ }^{1,2)}$ 、武藤厚子 ${ }^{11}$ 白石武昌 ${ }^{2)}$

【はじめに】訓練次第で精確な脈診を効果的に習 得できる “実践的な脈診習得のための訓練法 Practical Method for Pulse Diagnosis (PMPD)" を構築し報告してきた。今回は、脈診部位を脈診 時の手関節・时関節の位置の変化が表層・深部組 織にいかに反映するかを超音波画像より確認する ことなどにより、安定性・再現性・客観性を持つ, 「正しい脈診法」を目指す上で興味ある知見が得 られたのでその一部を報告する。

【方法】本研究に同意を得た男性37名、女性36 名（平均年齢31.5歳）を被験者とし(1)第2 4 指 爪甲根部幅（3指幅）(2)尺沢〜太淵距離（前腕の 長さ）(3)手関節横紋〜高骨距離（高骨距離）(4)母 指〜中指尺を測定し,(2)と(3)においては肘伸展位 と肘屈曲位の 2 肢位で測定した。手関節・时関節 の角度を変え、脈診右関上部における体表から骨 までの深さ、橈骨動脈の直径・深度を超音波画像 で計測した。

【結果】「前腕の長さ」は、肘伸展位 $(24.7 \pm 2.0$ $\mathrm{cm} 、 \mathrm{n}=60)$ は肘屈曲位 $(21.4 \pm 1.6 \mathrm{~cm})$ より有意 （p<0.001）に長かった。「母指〜中指尺」は20.2 $\pm 1.6 \mathrm{~cm}$ であった。「母指〜中指尺」に対する前 腕の割合は肘伸展位1.23、肘屈曲位1.07であつた。 「前腕の長さ」に対する3指幅 $(4.6 \pm 0.4 \mathrm{~cm})$ の割 合は、肘伸展位で 0.19 、肘屈曲位で 0.22 となつた。 「指幅」が $4.6 \pm 0.4 \mathrm{~cm}$ 、「高骨距離」は肘伸展位 で $1.25 \pm 0.36 \mathrm{~cm}$ 、肘屈曲位で $1.15 \pm 0.31 \mathrm{~cm}$ であっ た。3指幅に対する高骨距離の割合は、肘伸展位 0.27 、肘屈曲位 0.25 となり、高骨の位置と、実際 に中指が当たる位置とはすべての被験者で一致を みることがなかった。超音波画像による計測結果 では右関上部の骨までの深さと血管、それらと5 段階の浮・沈スケールの評価の変化との関連を認 めた。

【結語】今回の実験から(1)被験者の尺沢〜太淵距 離により検者の指幅を調節する必要性(2)脈診で中 指の位置は高骨よりも近位となる(3)肢位の相違が, 脈診部位や橈骨動脈の位置と,脈位脈状に影響す る可能性があることなどを確認した。この認識を もって脈診を学べば,客観性と再現性のある精度 の高い判定が可能となり,同一被験者の脈に対し て,検者間で統一された判定基準を持つことが可 能となる。

キーワード：脈診トレーニング法、PMPD、超音 波画像、橈骨動脈 


\section{P-D-14: 14 \\ 橈骨動脈拍動部からの圧脈波検出方 法の検討}

東京衛生学園臨床教育専攻科

大久保淳子、會澤重勝

お茶の水女子大学ライフサイエンス専攻

會川義寛

【目的】脈診は切診のなかでも重要な位置を占め、 臨床にこれを導入している治療家は少なくない。 しかしながら指頭感覚による判断であり、流派に より指の当て方や、押さえる圧に違いが見られ、 再現性や客観性を問題視する向きもある。脈診を 客観化するためには、圧センサーを用いる方法が ある。圧センサーの押圧方法は、固定された台か ら伸ばした棒の先にセンサーを固定して行う方法 や、術者の指と拍動部間にセンサーをはさんで計 測する方法等が試みられている。いずれも外部の 振動や微細な体動が、測定波形に重なり易い。今 回、我々は軽量の計器を測定部に装着することで、 これらの影響を排除し、任意の圧で脈波の導出が できる方法を考案し、若干の所見を得たので報告 する。

【方法】圧センサー（PM10ST研究所）を、ア クリル製の円筒内でネジにより上下に動く棒の先 端に固定し、外筒はマジックテープで脈診部に固 定する構造とした。安静臥位の健常成人の橈骨動 脈拍動部にセンサー部を固定し、センサーが皮膚

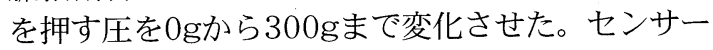
の出力は歪アンプ (DPM-611A共和電業) で増 幅後、押圧を含む全成分と変動部を分離して記録 し検討した。

【結果および考察】脈波は押圧が0のときは検出 できないが、押圧を増加すると共に波高が増し、 最大となり、その後再び小さくなつた。脈波が最 大值の示す押圧の大きさは被験者により異なった が、このときに脈波は最も鮮明であった。鮮明な 圧脈波を得るためには至適圧があると考えられる。 この圧は個人差があり、性別・年齢・体重等との 関係を現在検討中である。

【結語】新たに開発した脈波センサーにより、周 囲の振動を排除して鮮明な脈波を安定して導出で きた。脈波の導出には至適圧が存在すると考えら れた。

キーワード：脈診、橈骨動脈拍動部、圧脈波、開 発
2P-D-14:28

難経腹診の研究

一圧痛部位と症状との関連性について一

明治鍼尒大学東洋医学基礎教室

山本晃久、篠原昭二

明治鍼众大学大学院

森定 真、北出利勝

【目的】難経の第十六難に記載されている腹診は、 東洋医学的な鍼尒診断法の一つとして活用されて いる。しかし記載内容が漠然としており、腹診の 部位や症候との関係については明確にされていな いことも多い。今回、難経腹診において、心・肝 · 肺・腎の部における圧痛の有無と症状の調査を行 い、各部の圧痛出現と症状との関係について検討 をしたので報告する。

【方法】健常成人学生ボランティア40名を対象 とした。圧痛部位の調査は、臍を中心として、正 中線上は、胸骨体下端から臍上縁を心、臍下縁か ら恥骨結合上縁を腎とし、横断線上は、右乳頭線 との交点から臍右縁を肺、左乳頭線との交点から 臍右縁を肝として、それぞれを基準線とした。4 直線上を指頭にて按圧しながら圧痛の有無を確認 し、各配当の圧痛の出現状況を調査した。また臍 から圧痛点までの距離を測定し、基準線の距離に 対する百分率を求めた。症状は、難経第十六難、

五臓に関係する症状等を基礎とした 90 項目の症 状を聴取し、症状の強さの程度を $0 \sim 3$ 点で表現 した。

【結果】各配当（心・肝・肺・腎）における圧痛 出現の部位は、臍から 20〜 50\%の部位での出現 が多く見られた。圧痛と症状との関係では、各臓 の症状点数との間で相関は見られなかった。しか し、肝と目の症状、肺と鼻の症状、肺と喫煙にお いて相関が見られた。

【考察】今回は健常者による調査であったが、難 経腹診の肝および肺の部位における圧痛が東洋医 学的な関連症状と関係のあること、肺の部位の圧 痛が喫煙と関係のあることが示唆された。

【結語】難経腹診における圧痛部位と症状との関 係を調査した。その結果、圧痛部位は、臍から $20 \sim 50 \%$ の部位での出現が多く見られ、肝と肺 の部位における圧痛と五官の症状および肺の部位 の圧痛と喫煙において相関が見られた。

キーワード：腹診、難経、五藏、五官 


\section{P-D-15:00 \\ 腎不全患者と鍼炎外来患者における 音響学的音声解析}

明治鍼众大学大学院東洋医学基礎

関 真亮、北出利勝

明治鍼尒大学東洋医学基礎教室篠原昭二

【目的】東洋医学における診断法 (四診) の一つ に音声を聴覚的に診察する声診がある。しかし、 声診は他の診察法に比べ、臨床的意義などが明確 にされておらず、研究もほとんど行われていない のが現状である。そこで今回、疾患に特異的な音 声指標を明らかにするため、慢性腎不全患者と鍼 众外来患者の音声について音響学的検討を行つた。

【方法】対象は本研究に同意した琵琶湖大橋病院 にて維持透析中の慢性腎不全患者35例（62 111 歳)。対照群は明治鍼众大学附属鍼众センターに 来院した患者40例（66 11 歳）とした。音声標 本は自然な大きさ、高さで約 2 秒間発声された日 本語母音「あ」とし、DATレコーダーに録音後、 音声解析ソフトにて基本周波数と音声スペクトル を求めた。また、東洋医学の「腎」の状態につい て調査するため、10項目の問診票を用いた。

【結果】音声の高さを示す基本周波数について両 群に有意な差は認められなかつた。音声の質を示 す音声スペクトルについては、2〜 8kHz域のエ ネルギーレベルが腎不全群では有意に高いことが 認められた。問診票の平均は腎不全群で $5.6 \pm 2.0$ 点、鍼众群では3.6土1.8点であり、項目別にみる と尿に関する項目で差が見られた。

【考察】基本周波数は声帯の振動数を示し、物理 的要因として声帯の長さや質量によって決定され る。本研究では腎不全群と対照群に差が認められ なかったことから、音声の高さによって慢性腎不 全を診断することは困難である可能性が示唆され た。音声スペクトルにおいて $2 \sim 8 \mathrm{kHz}$ の高周波 域のエネルギーレベルが高いことは、聴覚的に雑 音が多いことを示し、臨床における声質の聴覚的 評価の必要性が示唆された。また、問診票の尿に 関する項目に差が見られたことから、慢性腎不全 による乏尿と声質が関連する可能性が示唆された。

【結語】慢性腎不全患者を対象に音声を解析し た結果、音声の高さに特徴はみられなかったが、 声質に雑音があることが示された。

キーワード：聞診、音声、基本周波数、音声スペ クトル、血液透析

\section{P-D-15: 14 \\ 舌診の色識別と証判断の検討}

明治鍼众大学東洋医学基礎教室

和过 直、篠原昭二、山本晃久

渡邊勝之、水沼国男

【目的】舌診における舌の色判断は寒熱や血の状 態を診るのに活用され、証判断の重要な所見となつ ている。舌の色判断は診察者個人の能力や臨床経 験による影響が大きいと考えられている。昨年、 我々が診察者の色識別能を調査したところ、舌写 真8枚の比較における色識別能検査では診察者個 人の臨床経験には差がないことが判つた。そこで、 我々は診察者に舌写真を一枚ずつ提示し、色識別 能を調査した。また、同時に舌写真から舌証を判 断させ、その一致率を検討した。

【方法】対象は8例の健常成人 (平均年齢；29歳) とした。調査は舌写真6枚を用意し、色彩計の測 色で得た舌色・苔色の色分類の測定值を参考に、 舌写真を色分類した。また、その分類を基に舌証 を判断した。次に舌写真をコンピュータの画面上 に無作為に一枚ずつ出力し、対象者に舌色と苔色 の判断、寒熱の証判断を行ってもらった。色判断 と証判断はそれぞれ5段階のCategorical Sscale (CS) とVisual Analogue Scale (VAS) を用い て評価し、調査者による色分類及び舌証の判断と の一致率をみた。なお、調査環境は外光から遮光 された一定光源下で行った。

【結果】舌色の判断ではCS評価の一致率35\%、 VAS評価 $56 \%$ 、苔色の判断ではCS評価の一致率 54\%、VAS評価58\%、証の判断ではCS評価の一 致率 $40 \%$ 、VAS評価 $52 \%$ であった。舌色、苔色、 証の判断は調査者の解答との一致率が低かった。 また、いずれの判断もCS評価よりもVAS評価の 方が一致率が高かった。

【考察・結語】舌診を用いる上で舌の色識別は重 要な項目である、色識別は微妙な判断であり、特 に対照比較のない色識別では個人の主観によると ころが大きい。本調査では舌色、苔色、証の判断 ともに一致率が低かった理由は舌写真の問題、調 査対象者の例数や臨床経験などが考えられた。今 後はこれらのことも検討を加えたい。

キーワード：舌診、舌色、苔色、色識別、証判断 


\section{P-D-15: 28 \\ 内臓反応点を指標とした四肢刺激効 果の影響と機序}

神戸東洋医療学院

河村廣定

【目的】内臓疾患を対象とする銊众治療において 俞募穴や切診上の特異点（反応点など）を用いる 例は多いが、それらの報告では刺激法が多様であ り刺激の質量と生体反応の関連が不明瞭である。 末梢神経を継続して刺激すると中枢において修飾 されることから、一過性の刺激と継続的刺激とで は異なる生体反応を生ずる可能性が考えられる。 そこで、四肢、背部などに断続的に鋏刺激を加え、 刺激量依存性に影響される内臓の反応点領域を調 ベ、鍼众治療がどのような神経機序を介して、そ の反応点に影響するのかについて検討した。

【方法】神戸東洋医療学院の学生28名を数名ず つのチームに分け、被験者はベットに仰臥位になつ た。その他の者は各個に胸部、上腹部、および下 腹部に指先で触れ、反応点と思われる範囲をマジッ クで記入し、足三里、合谷、大腸俞などの経穴を 選択して鍼众刺激を加えた。刺激法は約 $1 \mathrm{~cm}$ 刺 入後、撚鍼30secを加え、3分間隔で3回繰り返し て抜鍼した。撚鍼の都度、反応点に触れ感覚的な 変化を 10 点法で記録した。刺激終了後3.6分時に 同様に反応点の変化を観察した。各自が記録した 反応点の変化を経時的に集計し、刺激部位の違い と反応点改善率の違いから、鍼刺激がどのような 神経機序を介するのかについて検討した。

【結果および考察】上下肢の経穴刺激で下腹部、 上腹部、胸部反応点の変化を比較すると、下肢刺 激群では胸部反応点の変化率に比較して腹部の反 応点変化率が高かった。上肢刺激群では下肢刺激 群と反対に胸部反応点の変化率が高かつた。また、 反応点は四肢刺激で充分には消失せず、反応点部 の直接刺激によって消失した。したがって内臓の 反応点に対する刺激効果は、刺激部位の春髄神経 支配レベルの近位春髄が強く影響され、体性自律 神経、あるいは体性内藏反射などを介して、それ らに作用したと考えられる。

【結語】鍼尒刺激による内臓反応点の変化は、そ の脊髄神経レベルに近隣する反射弓を介して影響 される。

キーワード：四肢、鍼刺激、反応点、内臓、春髄 反射

\section{P-E-09:00 \\ 鍼刺激に伴う一過性心拍減少反応 に関する検討}

一仰臥位および坐位姿勢時における変化の比較一

明治鍼尒大学臨床鍼尒医学 II 教室

妹尾千鶴子、香村真由、靯矢哲生

今井賢治、北小路博司

【目的】これまでに鍼刺激により心拍数の減少反 応が誘発されることが知られている。しかし、体 位変化に伴うその反応への影響は充分明らかには なっていない。今回は、健常人を対象とし、安静 仰臥位および坐位時の鍼刺激に伴う心拍数減少反 応の出現動態の違いを観察した。

【対象および方法】健常人ボランティア 20 名 （男女各 10 名、平均年齢 23 才）を対象とした。測 定用電極を胸部に装着し、ポリグラフを使用して 心電図を記録した。得られた心電図のR-R間隔か ら瞬時心拍数を算出した。10分間の安静の後、 手三里穴に1分間の雀豚を行い、これを坐位姿勢 と臥位姿勢で行った。尚、一被験者あたり両姿勢 での刺鍼をランダムに行い、それぞれの刺鍼によ る心拍数の変化を比較した。

【結果】臥位に比べて坐位の方が、基準心拍数が 高くその差は約 10 拍程度であった。刺鍼に伴う 心拍数減少反応は、臥位での平均減少幅は3.6拍 であったが、坐位では7.0拍であった。このこと から、坐位の方が刺鍼に伴う心拍数減少が大きく 引き起こされていることが判つた。

【考察】今回、坐位により交感神経機能を元進さ せた状態での刺銊時の反応と、安静臥位での反応 を比較したところ、坐位で心拍数の減少が大きく 認められた。すでに、刺鍼に伴う心拍数減少反応 の機序は、副交感神経を充進させるという説、あ るいは交感神経の抑制と副交感神経の六進の両方 が関与しているという説などが報告されているが いずれも安静臥位で確認された結果に過ぎない。 今回の結果からは少なくとも、坐位で基準心拍数 を高值にした際には刺鍼に伴い心拍数は大きく減 少するということが判り、今後その詳細な機序の 検討が必要であるものと思われた。

キーワード : 鍼、瞬時心拍数、心電図R-R間 


\section{P-E-09:14 \\ 鍼刺激が循環系自律神経機能に及 ぼす影響}

一圧痛点への鍼刺激による検討一

早稲田医療専門学校東洋医療鍼尒学科

二本松明、小岩信義、所 数樹、浅野貴之 坂本真紀、鈴木盛夫、町田雅秀 昭和大病院リハビリテーション科隹 武

【目的】鍼众の臨床では種々の疾患に対し圧痛、 硬結等の生体反応を重視し、施術を行う。その際、 刺激部位の状態の違いが生体に及ぼす影響を検討 することは、有効な施術を行う上で重要である。 今回は筋の伸張性収縮運動により圧痛点を作成し、 それに対する鍼刺激の影響を心拍とそこから得ら れるパラメータを指標に検討した。

【対象及び方法】対象は健康成人7名 (男3例、女4 例、 $28.0 \pm 8.6$ 歳）とした。内訳は運動負荷約 24 時間後に鍼刺激を行う鍼 $\mathrm{A}$ 群（男 2 例、女 2 例）、 運動負荷を行わず鍼刺激のみ行う銊 $B$ 群 (男 1 例、 女2例）とした。圧痛点作成のための運動負荷は、 非利き手の前腕伸筋群に伸張性収縮運動を 2 セッ 卜行わせた。鍼刺激の部位は非利き手の手三里穴 （手の陽明大腸経）とした。心拍測定は、非観血 的連続血圧測定装置BP-508（COLIN社）を用い 仰臥位で行い、28分間連続測定した。この間鍼は 5 分目に刺入し、26分目に抜去した。刺銊中、1 回20秒の旋撚術を5分おきに行った(計3回)。鍼 は $50 \mathrm{~mm} ・ 20$ 号のディスポ銊を $20 \mathrm{~mm}$ 刺入した。 心拍は、第 II 誘導より得られた心電図R-R間隔の 值を用い、その変動をスペクトル解析した。

【結果及び考察】鍼A群では運動負荷により手三 里部周辺に圧痛を認めた。3回の旋撚刺激により 鍼 $\mathrm{A}$ 群、鍼 $\mathrm{B}$ 群ともにR-R間隔が、刺鍼直前に比 ベ延長する例を認めた。各旋撚終了後は鍼A群で は鍼B群に比べ延長する例を多く認め、延長した 例では心拍変動スペクトルHF成分が増加した。 心拍変動スペクトルHF成分は心臟迷走神経活動 の指標とされている。このことから鍼A群で各旋 撚終了後に認めたR-R間隔の延長は心臓迷走神経 活動の六進により起きたものと考えられる。鍼刺 激は刺激部位の受容器の感受性の違い等により、 循環系自律神経機能に異なる影響を与える可能性 が考えられる。

キーワード：鍼刺激、循環系自律神経機能、R-R間 隔、心拍変動スペクトル解析、圧痛点

\section{P-E-09: 28 \\ 手技別の鍼刺激による循環動態への 影響}

中和医療専門学校

明治鍼尒大学健康鍼尒医学教室

黒野由利子

矢野 忠

【目的】演者らは先の研究で、内関穴鍼刺激が狭 心症患者の冠動脈内径に影響を与え、また、自律 神経活動の異なつた状態において健常者での循環 動態の変化、特に心拍出量や筋交感神経活動 （MSNA）が有意に減少するとの結果を報告して きた。今回、臨床で比較的使用頻度の高い手技と 思われる刺鍼手技を数種選択し、それらの鍼刺激 が自律神経活動の異なった状態での循環動態に与 える影響に違いがあるかどうかついて検討したの で報告する。

【方法】健常成人ボランティア 22 名（男性14名、 女性8名、平均年齢27歳）を対象とした。測定項 目は血圧、心拍数、心拍出量で、刺激部位は内関 穴とした。鍼刺激は置鍼5分、雀豚2分、捻鍼2分、 鍼通電 $(1 \mathrm{~Hz} 、 5 \mathrm{~V})$ 10分とした。鍼は長さ 40 $\mathrm{mm}$ 、直径 $0.18 \mathrm{~mm}$ のステンレスディスポーザブ ル鍼を使用した。自律神経活動の異なる状態とし て、仰臥位と立位を採用した。

【結果】鍼刺激前の安定している部分を $100 \%$ と し、各手技別の測定項目を変化率で表した。仰卧 位における各手技別の心拍出量の変化は、すべて の測定項目において変化は見られなかつた。一方、 立位における各手技別の心拍出量はいずれの手技 においても減少が見られ、特に置鍼 5 分、捻鍼 2 分、鍼通電10分の刺激では有意な減少が観察さ れた。血圧及び心拍数はすべて有意な変化は見ら れなかったが、立位においては心拍出量との反応 と同様の傾向を示した。

【考察と結語】仰臥位での鍼刺激はいずれの手技 においても心拍出量は変化せず、立位での鍼刺激 はいずれの手技においても心拍出量に変化が現れ、 なおかつ、血圧や心拍数の変化もそれぞれ同様の 変化を示したことから、今回選択した鍼刺激の種 類は同様の反応により心臓機能に影響を与えたと 考えられる。また、鍼刺激の手技により、反応の 大きさが異なったことから、各手技は生体に与え る刺激量が異なることも示唆された。

キーワード : 内関、心拍出量、銊刺激、手技別、 体位変化 


\section{P-E-09: 42 鍼炎治療の血圧および脈拍に及ぼす
影響について}

関西鍼众短期大学鍼众学臨床教室

池藤仁美、坂口俊二、中吉隆之、川本正純

【目的】本態性高血圧症に対する鍼炎治療の血圧 調節については、一定の降圧効果が報告されてい る。しかし、高血圧症以外の患者の鍼尒治療によ る血圧・脈拍変動については報告が少なく、今回、 我々は治療前後の血圧・脈拍数を測定し、降圧剂 服用、非服用患者の変動について検討を行つた。

【方法】対象者は、本学附属鍼炎治療所の患者で、 口頭にて同意の得られた18～82歳の 96名（男43 名、女53名、平均年齢54.1歳）であった。治療 前、治療後の血圧・脈拍を、左上腕部で $2 \sim 3$ 回 連続的に測定した。測定には、オムロンデジタル 自動血圧計 HEM-907を使用した。

【結果】対象者を降圧剤を服用している群21名 (「服用群」) と、そうでない群99名（「非服用群」） に分類した。「服用群」において治療後に有意な 血圧変化はみられなかったが、脈拍の有意な低下 がみられた（6.5拍、 $\mathrm{p}<0.0001)$ 。「非服用群」で は治療後に収縮・拡張期血圧ともに有意な上昇 (収縮期 $3.1 \mathrm{mmHg} 、 \mathrm{p}<0.05$ 、拡張期 $2.1 \mathrm{mmHg}$ 、 $\mathrm{p}<0.005)$ と脈拍の有意な低下がみられた（5.3拍、 $\mathrm{p}<0.0001)$ 。さらに、「非服用群」の血圧を WHO/ ISH（1999）の基準で分類し、検討した結果、

「正常血圧」の収縮期 $(3.8 \mathrm{mmHg} 、 \mathrm{p}<0.05)$ と 「至適血圧」の収縮・拡張期血圧が有意に上昇し ていた (収縮期 $4.1 \mathrm{mmHg} 、 \mathrm{p}<0.05$ 、拡張期 3.2 mmHg、 $\mathrm{p}<0.05)$ 。

【考察】鍼众治療後の脈拍減少と血圧上昇は、副 交感神経機能の克進と、その変化に誘起された交 感神経機能の六進によるものと考えられ、降圧剤 の服用者では、その作用により副交感神経機能立 進に伴う交感神経機能の誘起現象が起こり難かっ たと考えられる。

【結語】鍼尒治療により、降圧剤服用の有無に関 係なく、脈拍は減少するのに対し、血圧は降圧剂 を服用していないものでは若干上昇することが示 唆された。

キーワード：鍼众治療、自律神経、血压、脈拍

\section{P-E-10:00 \\ ラットの末梢神経再生に及ぼす鍼通 電刺激の影響}

明治鍼尒大学健康鍼尒医学教室

井上基浩、矢野 忠

明治鍼众大学整形外科学教室

北條達也、勝見泰和

【目的】末梢神経の再生促進に対する鍼治療の臨 床的応用の基礎的研究として、ラットを用いて、 末梢神経の再生に及ぼす鍼および低周波鍼通電刺 激の影響を機能学的に検討した。

【方法】55匹の成熟ラットの坐骨神経に圧挫損 傷を与え、4つの実験群 (Control群、Sham群、 末梢陰極群、末梢陽極群）に分けた。末梢陰極群 は、圧挫損傷部の近位側と遠位側に絶縁鍼を刺入 し、遠位側を陰極とした直流鍼通電刺激を毎日行つ た。刺激条件は $1 \mathrm{~Hz} 、 10 \mathrm{~V} 、 15$ 分間とした。末 梢陽極群は末梢陰極群の極性を逆にし、遠位側を 陽極とした。Control群は圧挫損傷後、処置を行 わなかつた。Sham群は鍼の刺入のみ行い、電気 刺激は行わなかった。神経再生の評価は、圧挫損 傷後 1 週、 2 週、 3 週、4週に行い、評価項目は足 底部12部位における誘発EMGの出現率、潜時、 behavioural test score、前脛骨筋の筋湿重量、 組織学的評価とした。

【結果】すべての評価項目において、Control群 とSham群の間に有意差は無かった。しかし、す べての評価項目において、末梢陰極群はControl 群と比較して有意に良好な結果を示し、未梢陽極 群はControl群と比較して有意に劣悪な結果を示 した。

【考察と結語】以上の結果から、鍼刺激のみでは 神経再生の促進に影響を及ぼさなかったが、低周 波鍼通電刺激は末梢神経再生に大きく影響するこ とが明らかとなつた。さらに、電極として使用し た鍼の極性が重要な意義をもち、末梢を陰極とし た直流鍼通電刺激は末梢神経の再生を促進し、末 梢を陽極とした直流鍼通電刺激は末梢神経の再生 を遅延することが明確となつた。末梢陰極群が良 好な結果であった理由として、1）神経再生に必 要な神経栄養因子・接着因子等が陰極に向かって 電気泳動する性質、2) 軸索損傷の二次損傷とし て生じる $\mathrm{Ca}^{2+}$ による近位断端の破壊の抑制等が考 えられた。鍼は深部組織への刺入が容易であり、 神経損傷後の神経再生の促進に有効な治療法とな る可能性が考えられた。

キーワード : 未梢神経、再生、低周波鍼通電刺激、 直流 


\section{P-E-10: 14 \\ ラット阻血下肢への鍼刺激による筋 血流の変化}

明治鍼众大学外科学教室 小田 棡、咲困雅 明治鍼众大学臨床鍼众医学 II 教室 明治銊众大学基礎鍼炎医学教室

今井賢治

新原寿志

【目的】大腿動脈を切断した下肢阻血モデルラッ トに鍼刺激を行い、筋血流の増加が得られるかど うか、放射性マイクロスフィアー法を用いて検討 した。

【対象と方法】実験には体重320～400gのSD系 雄性ラットを用いた。下肢の阻血は、麻酔下で右 大腿動脈を切断して作製した。鍼刺激は動脈切断 後、約 24 時間を経てから開始し、前脛骨筋に 0.2 $\mathrm{mm}$ のステンレス鍼を約 $3 \sim 5 \mathrm{~mm}$ 刺入して行った。 尚、鍼刺激の方法は置鍼あるいは鍼通電 $(50 \mathrm{~Hz}$ 、 $0.1 \mathrm{~V} 、 0.3 \mathrm{~ms})$ とし、各種の刺激時間 ( $5 \mathrm{~h} / \mathrm{day}$ 、 $1 \mathrm{~h} \times 5$ /day 、 $15 \mathrm{~min} \times 5 /$ day 、 $1 \mathrm{~h} /$ day 、 $15 \mathrm{~min} /$ day）で5日間連続して行った。動脈切断 7日後に放射性同位元素を用いたマイクロスフィ アー法で前脛骨筋の血流量を測定し、無処置対照 群、大腿動脈切断群、切断十置鍼群、切断十各種 の鍼通電群で比較した。さらに筋萎縮の程度を比 較するため、健側肢に対する阻血肢の重量比を算 出した。

【結果および考察】大腿動脈切断群では明らかな 筋血流の低下が認められた。一方、切断に鍼通電 を加えた群では血流量の増加を確認した。

$5 \mathrm{~h} /$ day、 $1 \mathrm{~h} \times 5 /$ day といった長時間の鍼通電は 血流量の増加を引き起こす一方で、筋重量比は低 下していた。しかし $15 \mathrm{~min} \times 5 /$ dayの刺激では、 他群に比べ顕著に筋血流量が増加し、さらに筋重 量比の変化はなく、筋萎縮を引き起こさないこと が確認された。

キーワード : 鍼通電刺激、下肢阻血ラット、筋血 流量、放射性マイクロスフィアー法

\section{$2 \mathrm{P}-\mathrm{E}-10: 28$ \\ 数種の市販炎施炎時にみる皮膚局所 の微細構造特性}

関西鍼众短期大学解剖学教室

五十嵐純、東家一雄、木村通郎

【目的】食には様々な市販製品が用いられている が、それらの施众皮膚局所に与える影響について は定かでない。本研究では数種の市販众等を用い 施众時における皮膚局所を微細構造レベルで調べ、 それぞれの众による皮膚局所の微細構造変化の差 異を明らかにすることを目的とした。

【方法】実験動物：9週齢のWistar系雄性ラット 30匹（各群5匹）を用いた。施尒部位は前脛骨筋 の上三分の一の皮膚（足三里相当部位）に施尒し た。A群；直接众は約 $1 \mathrm{mg}$ の艾柱（山正） 3 壮の 連続施众とし、1 壮の艾柱が燃え尽きるごとに灰 を除去する群とB群; 灰の上に重ねて行う群に分 けた。間接众は、C群; 众熱緩和紙（众点紙、大 喜多商会）を用いA 群と同様の施尒を行う群、 D 群; 温筒尒（カマヤミニ (弱)、釜屋もぐさ本舗) を1壮行う群、 $\mathrm{E}$ 群; 台座众 (広重、亀屋佐京商 店）を1壮行う群とした。また無処置ラットを対 照群とした。組織学的検索 : 施炎48時間後に施 众皮膚局所を採取、型の如くエポン樹脂包埋を行 い、準超薄切片および超薄切片をつくり、光学顕 微鏡および透過電子顕微鏡で観察した。

【結果と考察】A群 : 施众直下中央の表皮および 真皮の浅層では上皮細胞や線維芽細胞の核および 膠原線維の走行が不明瞭となり、熱により強く破 壊されていた。しかし真皮の深層では膠原線維の 間に炎症性細胞が散在していた。B群もほぼ同様 の結果であった。C群 : 艾柱の中央直下の皮膚で は、表皮の破壊やdermo-epidermal junctionの 解離による水疮の形成、真皮浅層から深層にわた る炎症性細胞や線維芽細胞の散在が認められ、A 群およびB群に比べて弱い組織破壊像が認められ た。D群、E群共にほぼC群と同様の像を呈して いた。

【結語】直接尒と間接众では前者の施众皮膚局所 に強い熱性の変性がみられた。また後者でも温筒 众、食熱緩和紙、台座众いずれも程度に差はある が皮膚組織に損傷がみられた。

キーワード：ラット、皮膚、直接众、間接众、微 細形態 


\section{P-E-14:00 \\ 振動誘発指屈曲反射に及ぼす経皮的 通電刺激の影響}

日本鍼众理療専門学校 ${ }^{1)}$ 、(財) 東洋医学研究所 ${ }^{2}$ 、 昭和大学医学部第二生理学教室 ${ }^{31}$

矢嶌裕義 ${ }^{1,2)}$ 、平川稚佳子 ${ }^{22}$ 、高倉伸有 ${ }^{1,2,3)}$ 白石武昌 ${ }^{2)}$ 、本間生夫 ${ }^{2,31}$

【目的】指尖掌側に振動刺激を与えて誘発される 振動誘発指屈曲反射（VFR）が、反射誘発側ま たは対側の橈骨、正中、尺骨神経支配領域への鍼 刺激で抑制される事を報告した。今回は、橈骨 (少商穴)、正中（中衝穴）、尺骨（少沢穴）神経 支配領域それぞれに、侵害性（痛み刺激）、非侵 害性（非痛み刺激）経皮的通電刺激を与え、VFR 抑制効果について検討した。

【方法】被験者はインフォームドコンセントを得 た健康成人 5 名とした。被験者の右中指指尖掌側 に周波数 $60 \mathrm{~Hz}$ 、振幅 $1 \mathrm{~mm}$ の振動刺激を与え VFR を誘発した。中指の屈曲力は振動端子に取 り付けた荷重変換器により検出し、増幅器を介し ペンレコーダーにて記録した。経皮的通電刺激は SSP電極を用い、持続時間 $1 \mathrm{~ms} の$ 単一矩形波を右 少商穴、中衝穴、少沢穴のそれぞれに $1 \mathrm{~Hz} 、 5$ 分 間与えた。刺激電圧の強度を、0Vを対照 (cont) 群、電気刺激を感じ始める電圧の值をTouch Threshold（TT）群、痛みを感じ始める電圧の 值をPain Threshold（PT）群と設定した。指屈 曲力の測定は、各刺激部位のそれぞれの刺激強度 について刺激前、刺激中、刺激後に行つた。実験 結果の解析は振動刺激中に出現した中指の最大屈 曲力をVFRの指標とし、分散分析、Fisherの多 群比較を用いて行った。

【結果及び考察】TT群においては、いずれの部 位でもVFRはcont群に対して有意な減少は認め られなかつた。一方、PT群における各部位の通 電刺激中のVFRはcont群に対して有意 $(\mathrm{P}<0.05)$ に減少し、各部位間での減少には有意な差は認め られなかった。VFRが侵害刺激によって抑制さ れ、非侵害刺激によって抑制されなかったことは、 VFRの抑制には侵害刺激の入力が重要であるこ とを示している。侵害刺激で起こる橈骨、正中、 尺骨神経のいずれの皮膚求心性神経線維の活動が 指屈筋を支配する遠心性線維に対して同程度の抑 制効果を示したことは興味深い結果である。

キーワード：振動誘発指屈曲反射、経皮的通電刺 激、橈骨神経、正中神経、尺骨神経

\section{$2 \mathrm{P}-\mathrm{E}-14: 14$ \\ 屈曲反射を指標にした鍼刺激の響き 感覚の強さと鎮痛効果の関係につい $\tau$}

明治東洋医学院専門学校

角谷英治

【目的】鍼治療の効果発現には、響き感覚が重要 視されていが、響きの感覚の強さの差が鍼治療効 果に影響を与える可能性も考えられる。そこで、 痛みの程度の客観的指標として侵害刺激により誘 発される逃避性屈曲反射を用いて、鍼刺激の響き 感覚の強さと鎮痛効果の関係について調べた。

【方法】インフォームド・コンセントを得られた 健康成人 8 名（22-41歳）を対象とした。屈曲反 射の誘発刺激は右下肢外果後方を電気刺激するこ とにより行い、屈曲反射の記録は右大腿二頭筋外 側部から行った。電気刺激は反射筋電図の閾值の 約 1.1 倍の刺激強度とした（5trains、100Hz、 $2 \mathrm{~ms})$ 。銊刺激前として 10 秒毎に 10 回の電気刺激 を行つた後、鍼刺激中として同様の電気刺激に加 えて、左手三里穴へ、ほとんど響きを感じない鍼 刺激、心地よさを感じる中等度の響きを感じる鍼 刺激、きつさを感じる強い響きを感じる鍼刺激の 3 種類の鍼刺激のいずれかを行った（40mm、20 号鍼)。鍼刺激の響き感は、鍼刺激中持続的に感 じるように維持した。鍼刺激前と鍼刺激中の誘発 筋電図波形をそれぞれ加算平均し、誘発筋電図波 形が出現している $205 \mathrm{~ms} の$ 期間の筋電図積算振 幅値を算出し、銊刺激前と鍼刺激中で比較した。

【結果】ほとんど響きを感じない鍼刺激では、屈 曲反射の筋電図は312.6 $\pm 147.2 \mu \mathrm{V}($ mean $\pm \mathrm{SD})$ から $295.4 \pm 151.3 \mu \mathrm{V}$ へほとんど変化しなかつ た。中等度の響きを感じる銊刺激では $365.0 \pm$ $185.6 \mu \mathrm{V}$ から $254.9 \pm 152.7 \mu \mathrm{V}$ へ屈曲反射の 抑制が見られた。強い響きを感じる鍼刺激では $267.1 \pm 136.7 \mu \mathrm{V}$ から441.6 $\pm 197.2 \mu \mathrm{V}$ へと屈 曲反射の増大が見られた。

【考察および結語】「心地よさ」を感じる強度の 鍼刺激では鎮痛効果がみられたが、「ほとんど感 じない」弱い銊刺激および「きつさ」を感じる強 い響きの鍼刺激では鎮痛効果はみられなかった。 これの結果には、痛みに対する情動相が関与して いるものと考えられる。

キーワード：鍼鎮痛、屈曲反射、響き感覚 


\section{P-E-14:28 \\ マニュアル鍼刺激がヒト運動誘発電 位に及ぼす影響}

明治鍼尒大学基礎銊尒医学教室

村上高康、新原寿志、西村展幸、尾崎昭弘 明治銊众大学第一生理学教室

廖 登稔、西川弘恭

埼玉東洋医療専門学校

浦田 繁

【目的】本研究は、鍼刺激がヒト運動機能に及ぼ す影響を明らかにするために、種々のマニュアル 鍼刺激が、経頭蓋磁気刺激（TMS）により誘発 されるヒト運動誘発電位（MEP）に及ぼす影響 について検討すると共に、 $\alpha$ 運動ニューロン及び 筋の興奮性を反映するF波とM波に及ぼす影響に ついて検討した。

【方法】対象は、インフォームド・コンセントを 得た健康成人男性 7 名 $(26 \pm 3$ 歳) とした。第一背 側骨間筋（FDI）または小指外転筋（ADM）の MEPは、それぞれTMS刺激装置付属の8の字コイ ルまたは円形コイルを介して、任意の大脳皮質運 動野を磁気刺激することにより誘発した。銊刺激 は、FDIへ雀豚術 (刺激時間 1 分間、頻度 $1 \mathrm{~Hz}$ 、深 度 $10 \mathrm{~mm}$ )、回旋術 (1分間、 $1 \mathrm{~Hz} 、 3 \mathrm{~mm}) 、$ 単刺 術（10mm）のいずれかを与えることにより行っ た。FDIまたはADMのF波とM波は、手関節上の 尺骨神経に最大上電気刺激を与えることにより誘 発した。

【結果】FDIのMEP振幅比は、同筋への雀啄刺激 後1分と5分の時点で、それぞれ、70土7\%(平均士 標準誤差)、76 $11 \%$ であり、対照群(無刺激) と 比較して有意な抑制が観察された。( $<0.05$ 、 $\mathrm{p}<0.05)$ 。また、同刺激により ADMのMEP振幅 比も同等の抑制が観察された。しかしながら、 FDI への回旋術、単刺術ともに有意な変化は観察 されなかった。一方、FDIへの雀啄術による同筋 と $\mathrm{ADM}$ の $\mathrm{F} / \mathrm{M}$ 振幅比と $\mathrm{M}$ 波振幅比の変化は観察 されなかった。

【考察と結論】これらの結果から、雀豚術のよう な侵害性の強い鍼刺激は、刺激筋のみならずその 周辺筋の運動路を抑制することが明らかとなつた。 また、この抑制には、 $\alpha$ 運動ニューロンと筋の興 奮性はあまり関与しない可能性が示唆された。

キーワード：経頭蓋磁気刺激、運動誘発電位、F 波、M波

\section{P-E-15:00 \\ 白血球の自律神経における井穴 商、関衝) の反応について}

NPO法人東洋医学研究所 仲原泉子、水嶋丈雄

【目的】五俞穴の井穴は心下満を主治すると『難 経』68難に記載がある。安保・福田理論では関 衝以外の手の井穴は副交感神経を優位にするとさ れている。今回、我々は関衝と少商が自律神経に 影響を与えるか検討したのでここに報告する。

【方法】対象は患者35名のうち関衝に24名（男 性14名 女性10名 平均年齢53.2歳）少商に 10 名（男性7名 女性3名 平均年齢65.4歳）が長 さ $3 \mathrm{~cm} 、 0.14 \mathrm{~mm}$ のイリンディスポ鍼を用いて 刺鍼した。治療前と井穴治療後に血液検査を行い リンパ球（以下Ly）顆粒球（以下Gr）の数值を 測定した。

【結果】関衝群の平均値（Ly） 前 $29.0 \pm 10.0 \%$ 後 $31.9 \pm 11.2 \%(\mathrm{Gr})$ 前 $62.9 \pm 11.5 \%$ 後 $61.4 \pm 12.1$ \%。少商群の平均值 (Ly) 前 $34.5 \pm 10.6 \%$ 後 30.4 $\pm 10.6 \%$ （Gr） 前 $58.0 \pm 12.1 \%$ 後 $61.2 \pm 8.3 \%$ 。関 衝は治療後に（Ly）が増加（Gr）が減少した。 少商は治療後に（Ly）が減少（Gr）が増加した がこれらに有意差は認められなかった。しかし関 衝群を白血球5000以上と以下で分けると、5000 以上の群の（Ly）の平均值が治療前 $27.6 \pm 9.7 \%$ 後 $31.9 \pm 10.9 \%$ で有意差をもって増加した。 $(\mathrm{P}<0.1)$

【考察と結語】白血球の自律神経支配においては 白血球数と新陳代謝は関係する。白血球数が 5000 以上は実証、以下は虚証であるため生体側 の虚実で反応が変わると考えられる。関衝と少商 の群を比較すると少商は治療後に顆粒球の増加傾 向を示したことから交感神経優位になったことが 推察される。顆粒球の増加が多く認められた少商 の反応は古典に矛盾していないが、同じ井穴であ る関衝は生体側の虚実において効果が分かれた。 これは自律神経理論と合致するが三焦経は副交感 神経の作用が強いためと考えられる。

キーワード：自律神経、白血球、井穴、少商、関 衝 


\section{P-E-15: 14 \\ 鍼治療が尿中の過酸化脂質排泄量に 及ぼす影響}

中京女子大学大学院健康科学研究科 加藤豊広

【目的】酸素を使用してエネルギーを産出してい る生体には、常に酸化という危険性がつきまとう。 生体はこれらの酸化系に対する防御系を有してい るが、加齢に伴ってその作用が減弱し脂質過酸化 が充進すると考えられている。鍼众治療は、「足 の三里」の众などで知られるように、古来より健 康寿命を延ばすといわれる。そこで今回、治療前 後の尿中過酸化脂質の量を指標にして、鍼治療の 抗老化作用を検討した。

【方法】対象者は50代と 30 代の男性 2 名及び40 代と30代の女性それぞれ1名と20代の女性3名で、 そのうち2名は間隔をあけて 2 回実験を行った (延へ人数 9 名)。治療は古典的な全身調整である 「本治法」と肩こりなどの主訴に対して「局所治 療」をトリガーポイント療法で行った。尿は治療 前日（実験1日目）、治療日、治療の翌日5日、9日、 13日及び16日目とし、24時間尿を採取した。過 酸化脂質の測定はチオバルビツール酸法で、標準 物質としてマロンジアルデヒドを用いた。

【結果】治療前日の過酸化脂質量は、2086士 832nmol/日であったのに対して、治療日1889 土854、3日目 $1880 \pm 680$ 、5日目 $1832 \pm 6049$ 日 目 $1989 \pm 561$ 、 13 日目 $1806 \pm 439 、 16$ 日目 $1510 \pm 464 \mathrm{nmol} /$ 日（この日のみ被験者 4 名） となり、いずれも治療前日より過酸化脂質排泄量 は低下した。

【考察】鍼治療後の尿中過酸化脂質排泄量は低下 した。過酸化脂質生成量は日内変動が大きくかつ 日常生活活動強度によっても左右される。今後は 運動負荷などで過酸化脂質が大量に増加する条件 下で銊治療を行い、脂質過酸化を抑制する効果の 有無を検討したい。

【結語】鍼治療の脂質過酸化抑制効果を検討した 結果、鍼治療は有効である可能性が示唆された。

キーワード：鍼治療、過酸化脂質、抗老化作用

\section{P-E-15:28 \\ レモンの精油によるアロマ吸入が自 律神経系に及ぼす効果の評価}

杏林大学保健学部生理学教室

加藤幸子、秋元恵実、小林博子、嶋津秀昭 東海医療学園専門学校

谷 直樹

【目的】アロマセラピーは近年、代替医療として 注目を集め臨床への応用が行われ始めている。ア ロマセラピーで使用される精油は吸入、塗布、マッ サージ等により生体内に吸収させることで効用が あるとされており、その範囲は神経系、免疫系、 情動、内分泌等多岐にわたる。今回精油の吸入に より生体の自律神経系が受ける影響に着目し、循 環動態の分析および瞳孔反射の分析を行つた。さ らに、血管平滑筋の応答を血管中膜の弾性特性を 数值化して評価した。

【方法】健康成人 10 名を対象として、レモンの 精油をアロマポットで炊き15分間吸入を行った。 吸入直後より 5 分ごとに手掌温、手掌血流量、血 压、脈拍、血管弾性特性を計測し、吸入前と 15 分後に体温と瞳孔径を計測した。瞳孔径の計測に 際しては頭部を固定し、デジタルカメラにて眼球 部を記録し、画像上で直径を計測した。また、コ ントロール群は同様の項目を精油の吸入無しにて 計測した。

【結果】アロマ吸入群の変化のうち最高血圧、最 低血圧、脈拍ではコントロール群よりやや低下す る程度で有意差はほとんどみられなかった。上腕 動脈の弾性率も大きな変動は認められなかった。 さらに、体温、手掌温ではコントロール群、アロ マ吸入群とも有意差はなかった。これに対し、手 掌血流量ではコントロール群に変化がみられなかつ たが、アロマ吸入群は直後にやや低下し 15 分後 には安静時の約 $20 \%$ 増となった。また、瞳孔径 はコントロール群と比較して約 7\%小さかった。

【考察と結語】一般にレモンの精油に血行促進作 用があることが知られているが、末梢の血流量の 増加と同時に、瞳孔の縮小が認められたことから、 レモンの精油によるアロマ吸入には交感神経系の 抑制または副交感神経系の促進の効果が存在する ことが示唆される。

キーワード：アロマセラピー、血圧、血流、瞳孔 反射 


\section{0-C-09:00}

\section{機能性不妊に有効であったと考え} られる鍼炎治療（第2報）

-41歳で、鍼炎治療後に自覚症状及び他覚的身体 所見の改善が観察され妊娠に至つた 1 症例一

藤田保健衛生大学坂文種報徳會病院産婦人科 ${ }^{11}$ 藤田保健衛生大学坂文種報徳會病院 ${ }^{2)}$ 中和医療専門学校 ${ }^{31}$

$$
\begin{aligned}
\text { 清水洋二 }^{1,3)} \text { 、山口陽子 } & { }^{1)} \text { 、中沢和美 }{ }^{1)} \\
& \text { 岩田治郎 }{ }^{2)} \text { 、川瀬 馨 }
\end{aligned}
$$

【目的】一般に女性の生殖能力は30歳前後を境 に年齢とともに低下し、40歳を過ぎると妊娠は 困難になることが多い。前回我々は、28歳と31 歳の不妊症患者について不妊治療と鍼尒治療を併 用することによりBBT、子宮内膜、卵胞直径等 の改善が確認され妊娠に至った症例を報告した。

今回は 41 歳不妊患者で鍼尒治療前後で一般不妊 検査に変化無く自覚症状及び他覚的身体所見に改 善がみられ妊娠に至つた症例を報告する。

【症例】 41 歳、主婦、平成 9 年第 1 子出産。第 2 子 希望のため平成 12 年 7 月、当科に再来院。

続発性不妊症及び夫、無精子症にて再検査及び不 妊治療開始。月経は整25日〜30日、BBTは2相 性、排卵時の内分泌、卵胞直径及び子宮内膜厚は 妊娠可能レベルよりやや下であつた。自覚症状及 び他覚的身体所見は、睡眠不足感・脱力感・イラ イラ・手足の強い冷感（自・他覚的）及び下腹部 の張り軟弱、であった。不妊治療は、排卵誘発と AIDであった。平成13年8月より鍼众治療開始。 治療方法は基本的に週1回で、三陰交に食頭銊、 関元、中極、子宮点、次髎、腎俞に尒（温食2 3壮）を行った。

【結果】不妊治療により排卵時の内分泌、卵胞直 径、子宮内膜厚は妊娠可能レベルの範囲内に入っ た。更に鍼众治療併用後4回目手足の強い冷えが やや改善、10回目脱力感及びイライラ感改善、 28 回目睡眠不足感改善、34回目下腹部の張り軟 弱やや改善し 38 回目終了後、平成14年6月に妊娠 が確認された。

【考察及び結語】今回の症例は不妊治療によりルー チンの不妊検査で妊娠可能レベルを維持されたに もかかわらず不妊状態が続き、鍼众治療併用によ り、自覚及び他覚的身体所見の変化が回数ととも に明瞭となり妊娠に至つたものである。高齢不妊 の場合妊孕率は加齢とともに低下していく場合が 多いが、今回の結果より高齢の不妊症患者に対し て鍼众治療を併用する事により妊娠の可能性が上 がると考える。

キーワード：高齢不妊、自覚症状、他覚的身体所 見
30-C-09: 12

難治性不妊症に対する鍼炎治療の 検討（第4報）

一子宮内膜形状不良患者にART と鍼炎治療を併用 した57名の追試一

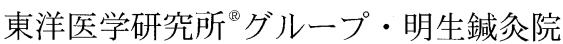
小林美鈴、高橋順子、鈴木裕明

【目的】第51回学術大会において「難治性不妊 症に対する鍼尒治療の検討（第1報）」と題して、 ARTを繰り返し行うも子宮内膜形状不良にて胚 移植に至らなかった難治性不妊症患者に対し、鍼 炎治療後のART1周期における子宮内膜形状改善 率と妊娠率を報告した。今回、第 1 報での対象患者 における 2 周期・ 3 周期の子宮内膜形状改善率と妊 娠率を追試検討したので報告する。

【方法】第 1 報における対象患者（子宮内膜形状 不良患者57名）の1周期における子宮内膜形状改 善群中、非妊娠群 17 名及び子宮内膜形状非改善群 26名の計43名を対象に鍼众治療を継続し、2周期・ 3 周期の各周期における子宮内膜形状改善率と妊 娠率、ならびに3周期終了時における累積した子 宮内膜形状改善率と妊娠率について調査検討した。

【結果】第 1 報の結果では、鍼炎治療併用後の 1 周 期における子宮内膜形状改善率及び妊娠率は 54.4 \%/45.1\%であったが、今回の結果では、2周期 では75.0\% / 44.4\%、3 周期では60.0\%/66.6\%と なつた。また、鍼众治療開始から 3 周期までの累 積した子宮内膜形状改善率は $92.5 \%$ 、妊娠率は $96.0 \%$ \%った。

【考察と結語】ARTを繰り返し行うも、子宮内 膜形状不良にて肧移植に至らなかつた対象患者が、 鍼众治療併用にて胚移植可能な子宮内膜形状に改 善し、妊娠率においても高い結果が得られた。 ART における 1 周期妊娠率は約 $30 \%$ 、その後 繰り返す毎に妊娠率は低下し（4周期以降10\%以 下）、愿生労働省研究班による累積妊娠率の報告 でも、ART5周期以降の 1 周期毎妊娠率が極端に 低下している。今回の対象患者の条件がART既 往周期 5 周期以上であることを考慮すると、鍼尒 治療併用・継続により5周期以上のARTを行って も、各周期の改善率及び妊娠率が共に高かったこ とより、鍼尒治療は子宮内膜形状不良の難治性不 妊症患者に対し効果があると示唆された。

キーワード：難治性不妊症、ART、子宮内膜改 善率、累積妊娠率、鍼尒治療 
30-C-09:24

\section{不妊症患者の不定愁訴に対する鍼 炎治療の検討（第1報）}

\author{
一妊娠群・非妊娠群における \\ 健康チェック表の分析一
}

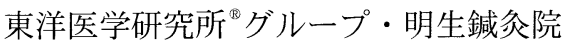

北國善太、片岡泰弘、沓名勇典、鈴木裕明

【目的】演者らは第51回学術大会において「難 治性不妊症に対する鍼尒治療の検討（第3報）」

と題して一般患者と不妊症患者との初診時におけ る不定愁訴の状態を比較検討した。今回、不妊症 患者377名を妊娠群 (以下A群)、非妊娠群（以 下B群）に分類し、初診時における不定愁訴の状 態を比較検討したので報告する。

【方法】1996.1〜2001.10までの5年10ケ月間に 明生銊众院に来院した不妊症新患患者 377 名（最 少年齢 23 歳、最高年齢50歳、平均年齢 $33.2 \pm 4.2$ 歳、平均不妊歴 $5.5 \pm 3.5$ 年）を対象として（社） 全日本鍼众学会研究委員会不定愁訴班が作成した 健康チェック表を使用し、A 群（142名）とB群 (235名）とに分け、以下の5項目において調査分 類し比較検討を行った。(1)重症度別分類(2)年齢別 分類(3)健康チェック表の層別分類(4)健康チェック 表の層別の各項目別分類(5)健康チェック表の各項 目別分類

【結果】(1)重症度別分類において健康チエック表 の合計点数の平均点及び重症度判定はA群におい ては14.8土8.5点で軽症、B群においては $17.0 \pm$ 10.1点で中等症となりB群の方が重症度において 高かつた。(2) A 群は最少年齢23歳、最高年齢40 歳、平均年齢 $32.0 \pm 3.6$ 歳となり B 群は最少年齢 24 歳、最高年齢50歳、平均年齢34.0 土4.4歳となつ た。(3)層別分類において差はなかった。(4)健康于エッ ク表の層別の各項目別分類において差はなかった。 (5)健康チェック表の各項目別分類において差はな かった。

【考察と結語】結果より初診時の年齢が40歳以 下であれば妊娠の可能性があると考えられる。ま た、不妊症患者が初診時に訴えている不定愁訴の 項目は妊娠の指標とはならなかつたが、不定愁訴 の重症度が低いと妊娠に至り易かった。これより 不妊症患者の初診時における妊娠の指標が不定愁 訴の重症度判定と年齢から判別できる可能性が示 唆された。

キーワード：妊娠群、非妊娠群、健康チェック表、 不定愁訴

\section{0-C-09:36}

\section{不妊症患者の不定愁訴に対する鍼 炎治療の検討（第2報）}

一不定愁訴指数の減少と妊娠との関係-

東洋医学研究所 ${ }^{\circledR}$ グループ・明生鍼众院

片岡泰弘、北國善太、沓名勇典、鈴木裕明

【目的】演者らは第51回学術大会で「難治性不 妊症に対する鍼众治療の検討（第3報）」にて初 診時における不妊症患者の不定愁訴に関する報告 をした。臨床上、経験的に不定愁訴の減少が妊娠 に関与することが示唆されていたが、経時的に追 跡調査を行い定量的に見出すことは無かった。今 回、以下の方法で調査検討をしたので報告する。

【方法】明生銊尒院に2001.5〜2002.6の約1年間 に来院した不妊症新患患者 266 名を対象に鍼众治 療を行い、（社）全日本鍼尒学会研究委員会不定 愁訴班が作成した健康チェック表を 3 クール（1 クールは7回の治療とする）の期間使用して不定 愁訴指数減少率を算出し、妊娠群（以下A群）と 非妊娠群（以下B群）における以下の3項目につ いて比較検討した。

(1)重症度判定(2)初診時から3クール間の重症度判 定の推移(3)効果判定

【結果】有効回答数は A 群 56 名中 26 名（平均年 齢 $32.8 \pm 3.1$ 歳、平均不妊歴 $5.8 \pm 3.9$ 年、平均治 療日数 $129.0 \pm 41.8$ 日）、B群 210 名中 87 名（平均 年齢 $34.6 \pm 4.4$ 歳、平均不妊歴 $6.1 \pm 3.5$ 年、平均 治療日数 $118.8 \pm 45.5$ 日）で合計266名中 113 名 (42.4\%) であった。

(1)初診時は A 群が軽症、B 群では中等症が最も多 く、A群が B 群より重症度は低かった。3クール時 は両群ともに軽症が最も多く差はなかった。(2) A 群・B群ともに不定愁訴指数は減少し、重症度は 3 クール時で軽症は不変、中等症は軽症に、重症は 中等症に改善した。(3)A群は有効 $46.2 \%$ 、著効 30.8 \%、B 群は著効 $41.4 \%$ 、有効 $29.9 \%$ の順であった。

【考察と結語】結果より、不定愁訴が少ないこと は妊娠に至り易く、不定愁訴の減少が妊娠に関与 すると考えられた。なお、非妊娠群においても同 様に不定愁訴が減少したことからは、非妊娠群に 対する将来の妊娠の可能性があるとともに、妊娠 に至るには不定愁訴の減少以外の要因が存在する ことも示唆された。

キーワード：不妊症、健康チエック表、不定愁訴 指数、重症度判定 


\section{0-C-09:48 \\ 不妊症患者の不定愁訴に対する鍼 炎治療の検討（第3報）}

一明生鍼尒院における不妊症患者の動向調査一

\author{
東洋医学研究所 ${ }^{\circledR}$ グループ・明生鍼众院 \\ 木津正義、北國善太、片岡泰弘 \\ 沓名勇典、鈴木裕明
}

【目的】演者らは第51回学術大会において「難 治性不妊症に対する鍼炎治療の検討（第3 報）」 にて初診時における不妊症新患患者377名の不定 愁訴に関する報告をした。今回は、前回の対象患者 の治療経過と動向を調査したのでここに報告する。

【方法】前回の対象患者377名に鍼尒治療を行い、 妊娠に至つた 142 名（平均年齢 $32.0 \pm 3.6$ 歳、平 均妊娠クール数 $6.2 \pm 5.1$ クール）及び途中で鍼尒 治療を離脱した 167 名（平均年齢 $34.2 \pm 4.7$ 歳） を対象とし、以下の5項目において調査分類し検 討を行った。(1)不妊歴別妊娠方法(2)不妊歴別妊娠 クール数（1クールは鍼众治療7回とし、7回に満 たないものは0クールとした） (3)年齢別妊娠方法 (4)年齢別妊娠クール数(5)鍼众治療離脱者の動向。 なお、妊娠方法を自然妊娠、一般不妊治療、高度 生殖医療（以下ART）と区分した。

【結果】(1)不妊歴5年未満における妊娠方法にお いては差が見られず、不妊歴 5 年以上になると ART による妊娠が最も多かった。(2)不妊歴2年 未満では6クールまでに6割が妊娠に至つた。(3) 30歳以下では自然妊娠が最も多く、31〜 40歳で のARTによる妊娠は、自然妊娠や一般不妊治療 の約3倍であった。(4)30歳以下では6クールまで に5割以上が妊娠に至った。36歳以上では3クー ル未満での妊娠が最も多く、12クール以上は他 の年齢層に比べて少なかつた。どの年齢層におい ても9クールまでに約7割が妊娠に至った。(5) 2002.9 時点において 69 名が治療継続中であり、 離脱者（167名）の約5割は3クール未満で離脱し ていた。

【考察と結語】今回の結果より、不妊症治療に対 する鍼尒治療において、不妊原因や治療内容に関 わらず、9クール程度の鍼众治療回数が必要であ ると示唆された。また、鍼尒治療離脱者は3クー ル未満までに多くみられたことより、銊尒治療を 継続することの重要性が示唆された。

キーワード : 不妊症、不妊歴、妊娠クール数、妊 娠方法、鍼尒治療
30-C-10:00

\section{不育症に対する鍼炎治療の検討 （第1報）}

一反復流産患者における流産率の検討一

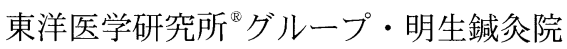

鈴木裕明、高橋順子、木津正義、小林美鈴

【目的】不育症の中でも、連続2回の流産を繰り 返す反復流産の原因は多岐に亘つており、西洋医 学においても解明が急がれているが、依然原因不 明の流産を繰り返すものも多い。そこで今回、この ような西洋医学的原因の不特定な反復流産患者に 対し銊尒治療の効果を検討したので報告する。

【方法】1998.5〜2002.5までの4年間に明生鍼尒 院を来院した西洋医学的原因の不特定な反復流産 患者28名のうち、鍼炎治療を一定期間継続し妊娠 に至つた18名（初診時の最少年齢26歳、最高年齢 39 歳、平均年齢 $31.0 \pm 2.8$ 歳、平均不妊歴 $4.0 \pm 2.8$ 年）を対象とし、流産率及び生児獲得率について 調査検討した。

【結果】対象患者 18 名中、流産群 3 名 (流産率 $16.7 \%$ ）、生児獲得群15名（生児獲得率83.3\%） となった。

【考察と結語】一般に偶発的自然流産頻度は 13.0 〜 15.0\%であるが、反復流産における3回目妊娠時 流産率は31.8〜 43.7\%と連続した流産は流産率が 高くなることは種々報告されている。しかし、今回 の結果より、対象患者は鍼炎治療を行うことで、偶 発的自然流産頻度と同様の低い流産率（16.7\%) が得られたことより、鍼众治療は反復流産に対し 効果があったと示唆された。近年、反復した流産を 経験した者は医療機関を受診し、検査及び治療を 受けることを望む夫婦が増えてきており、また、専 門医療機関においても反復因子を究明する対象者 と考え、検査を進めることを妥当としている。今回 の結果より、鍼尒治療が反復流産に対して効果が あったことから、銊众治療も一選択肢の可能性が あると考えられる。さらに、胎児が拒絶されず妊娠 継続するには巧妙な免疫学的妊娠維持機構の関与 が容易に想像されること、生体における鍼尒治療 効果の免疫学的関与が多数報告されていることか ら、不育分野における鍼众作用機序の解明を今後 の課題としたい。

キーワード：反復流産、不育症、流産率、生児獲 得率、銊众治療 
30-C-10: 12

\section{不育症に対する鍼炎治療の検討 （第2報）}

一習慣流産患者における流産率の検討一

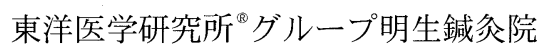

高橋順子、木津正義、小林美鈴、鈴木裕明

【目的】不育症の中でも、連続3回以上の流産を 繰り返す習慣流産は患者の認識も確立しており、 専門機関を受診し原因の究明を行うも、依然、原 因不明の流産を繰り返すものが半数である。そこ で今回、このような西洋医学的原因の不特定な習 慣流産患者に対し鍼众治療の効果を検討したので 報告する。

【方法】1998.5〜2002.5までの4年間に明生鍼众 院を来院した西洋医学的原因の不特定な習慣流産 患者14名のうち、鍼众治療を一定期間継続し妊娠 に至った7名（初診時の最少年齢29歳、最高年齢 39 歳、平均年齢 $34.0 \pm 3.7$ 歳、平均流産回数 $3.4 \pm$ 0.5 回、平均不妊歴 $5.6 \pm 2.6$ 年）を対象とし、流産 率及び生児獲得率について調査検討した。

【結果】対象患者 7 名中、流産群1名（流産率 14.3 \%) 生児獲得群6名（生児獲得率 $85.7 \%$ ）となつ た。

【考察と結語】一般に偶発的自然流産頻度は 13.0 〜 15.0\%であるが、習慣流産における次回妊娠時 流産率は44.6〜 60.0\%と連続した流産は流産率が 高くなると種々報告されている。しかし、今回の結 果より対象患者は鍼炎治療を行うことで偶発的自 然流産頻度と同様の低い流産率（14.3\%）を得た ことより、鍼尒治療は習慣流産に対し効果があっ たと示唆された。鍼众治療の不育症における作用 機序は不明であるが、不育原因の 1 つ宮動脈 の血流不全がいわれており、鍼尒治療が血流改善 に効果があることから、子宮動脈における血流改 善の可能性が示唆される。また、胎児が拒絶されず 妊娠継続するには巧妙な免疫学的妊娠維持機構の 関与が容易に想像されるも未だ不明であり、これ までにも銊尒治療が内分泌・免疫系等に影響を与 えるとの報告が多数あることから、婦人科 (不育) 分野でも何らかの関与が推察されることより、今 後、西洋医学的原因の不特定な不育症患者に対す る鍼尒治療による作用機序の解明を課題としたい。

キーワード：習慣流産、不育症、流産率、生児獲 得率、鍼尒治療

\section{$30-C-10: 24$ \\ 妊娠中の腰痛に対する鍼炎治療効果 の検討}

筑波技術短期大学鍼众学科

形井秀一

筑波技術短期大学附属診療所

青田忠洋、村山武志

【目的】演者らは、1998年3月から 2002 年11月 までの約 4 年 8 ケの間に、妊娠中の腰痛の患者 55名に対して鍼众治療を行い、一定の効果を得 ることが出来たので報告する。

【対象と方法】対象は腰痛を訴える妊婦55例で、 平均年齢 $30.3 \pm 3.9$ 歳、初産婦 17 例、経産婦 38 例 であった。平均身長 $158.0 \pm 4.5 \mathrm{~cm}$ 、平均体重 $56.6 \pm 6.7 \mathrm{~kg}$ 、妊娠前に比べた平均増加体重（29 例） $7.3 \pm 9.0 \mathrm{~kg}$ 、平均血圧 $104.0 / 59.9 \mathrm{mmHg}$ で あった。平均罹病期間8.4 4 7.6週、平均治療日数 $30.0 \pm 32.9$ 日、平均治療回数 $4.0 \pm 2.8$ 回であつた。

刺鍼は、下腿か痛み局所の皮下に数ミリ刺入し、 単刺術や雀啄術を行つた。また、棒众を痛み局所 に行つた例もあつた。

治療の評価は、初診時の痛みの強さを 10 とし て、スコアが5〜 6となった場合をやや有効、3〜 4 となった場合を有効、2以下となった場合を著 効とした。

【結果】結果は終了 34 例、中断18例、継続3例で、 治療効果は、著効 26 例 $(47.3 \%)$ 、有効 13 例

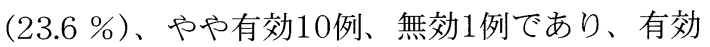
以上が39例 $(70.9 \%)$ であった。

【考察と結語】一般的に、筋筋膜性の腰痛に対し て鍼众は効果が高いと報告されているが、妊娠中 の腰痛55例に対しても、70\%以上と高い治療効 果を示した。

しかし、物理的な体重等の変化よりも、妊娠そ のものや以前から有する腰痛の影響が強いと考え られる妊娠早期に発症した症例に対しては、鍼众 の治療効果は低かった。また、全例に有害な事象 の出現は見られなかった。

キーワード：妊娠、腰痛、鍼尒治療、温尒、有害 事象 
「演題取り消し」

\section{子宮 · 卵巣点亡婦人科疾患との関連}

岐皁地方会

神戸東洋医療学院

松山幸枝、河村みゆき 河村廣定

【目的】月経困難症、不妊症などの婦人科疾患に は鍼众治療が有効であるとされている。それらで は生殖器の体表面に当たること、脊髄支配神経レ ベルが隣接していることなどから、下腹部に治療 点を求める例も見られる。一方、婦人科疾患は、 風邪などの炎症性疾患や、心理的要因にも影響さ れ、多くの要因によって、その病的状況は変化す ることが知られている。そこで、婦人科疾患によ く用いられる子宮・卵巣点の経穴反応と患者の愁 訴との経時的変化を調べ、それら治療点の診断的 あるいは治療的意義について検討した。

【方法】対象は平成14年1月から3月に来院した 女性患者7名（平均年齢33歳）に問診表の記入を 依頼し、月経周期、自律神経症状、頭痛などの身 体的症状、風邪の症状などについて調査した。通 院は週1回を原則とした。治療方法は中脘、期門 など内臓器官の代表点、婦人科疾患の関連として 子宮・左右の卵巣点を触診し、反応が消失するま で置鍼、撚鍼などの刺激を行つた。施術者側の所 見として、子宮・卵巣点の反応出現範囲に印を付 け、その面積を測定した。また子宮・卵巣点の反 応が消失するまでに要した手技や時間を刺激量と して記録し、反応点面積や加えた刺激量の経時的 変化、問診表との関連を調べた。

【結果および考察】問診表における身体的症状一 風邪の症状・自律神経症状との間に相関が認めら れた。しかし、それらと子宮点などとの関連は認 められなかった。また、子宮・卵巣点の面積と刺 激量は経時的に減少傾向を示し、それと同時に月 経周期も改善された。これらのことは、痛みや自 律神経症状が風邪によって誘発される可能性を示 唆している。同時に子宮・卵巣点の反応の大きさ やその程度が、女性生殖器機能と密接であったこ とから、それらの部位は婦人科疾患の診察や治療 に有用であることを示唆している。

キーワード：子宮点、生殖器機能、卵巣点、反応 点、風邪 


\section{0-C-13:00 \\ 手術侵襲による免疫抑制に対する術 前鍼通電の影響}

明治鍼众大学外科学教室

田口辰樹、咲田雅一

【目的】我々は昨年本学会において、術前鍼通電 が手術侵襲による術後の免疫抑制を防止すること ができたことから、そのメカニズムとして視床下 部-下垂体-副腎皮質系（HPA系）および交感神経 系（SNS系）による免疫抑制経路を鍼通電が抑制 することにより術後の免疫抑制を防止する可能性 について報告した。そこで今回、手術侵襲および 術前通電が血中 ACTH、コルチコステロン (HPA 系)、ノルアドレナリンおよびアドレナリ ン（SNS系）に及ぼす影響について検討した。

【方法】動物はSD系雄性ラットを用いた。手術 侵襲ラットは背部の皮膚を $6 \mathrm{~cm}$ 切開した後縫合 して閉創し、さらに腹部に $5 \mathrm{~cm}$ の正中切開を行 い、腸管を腹腔外に露出させ滅菌湿ガーゼで 30 分間被覆後、腹腔内に還納、縫合閉腹して作成し た。術後24時間、72時間後に脾細胞を用いてNK 細胞活性およびリンパ球芽球化反応を検討した。

さらに術後3時間、24時間、72時間後に血液を採 取し血中ACTH、コルチコステロン、ノルアド レナリンおよびアドレナリン量をEIA法および ELISA 法にて測定した。鍼通電は手術2日前から 開始し手術当日まで連日で計3回、一側後肢前脛 骨筋に $2 \mathrm{~Hz} 、 3 \mathrm{~mA}$ で1時間行った。

【結果・考察】手術侵襲によりNK細胞活性、リ ンパ球芽球化反応共に抑制されたが、術前鍼通電 はそれらの抑制を防止した。さらに手術侵襲によ り非鍼通電群の血中ACTH、コルチコステロン、 ノルアドレナリンおよびアドレナリンは術後著明 に増加した。一方、鍼通電群は非鍼通電群に比べ それらの值が有意に低值を示した。以上の結果か ら、術前鍼通電が手術侵襲による免疫抑制を防止 するメカニズムとして、HPA系およびSNS系に よる免疫抑制系路を銊通電が抑制した可能性が考 えられた。

キーワード：手術侵襲、免疫抑制、鍼通電、視床 下部-下垂体-副腎皮質系、交感神経
30-C-13:12

体性感覚刺激における腸管神経系 とCD11b陽性細胞の変化

一神経系と免疫系の関連一

横浜市立大学医学部解剖学第 2 講座 久島達也 富山国際伝統医学センター

上馬場和夫、田口裕紀子

【目的】体性-内蔵系に関する研究が多くある中、 銊刺激による効果も基礎研究によって明らかにさ れつつある。今回、鍼刺激が腹部消化器系に及ぼ す影響のメカニズムを解明するため、腸管神経系 および免疫担当細胞などに着目し、免疫組織化学 的な検討を行つた。

【方法】ネンブタール麻酔下ICRマウスの三叉神 経第1枝領域に刺鍼し、30分間捻鍼した。その後、 灌流固定し、結腸を剖出、10 $\mu \mathrm{m}$ の凍結切片を 作成し、Protein Gene Product (PGP) 9.5、 Tyrosine Hydroxylase (TH), Serotonin (5-HT), Neuropeptide tyrosine (NPY)、 neuronal NO-synthase (nNOS)、 Vasoactive Intestinal Peptide (VIP)、Substance P (SP)、CD11b抗 体を用いて蛍光免疫組織化学重染色を行つた。

【結果】鍼刺激群ではPGP9.5、TH、5-HT、NPY、 VIP、SP陽性反応の増加がみられた。VIP 陽性反 応は筋間神経叢、粘膜下神経叢および絨毛中に、 SP陽性反応は筋間神経叢中に多く確認した。一 方、nNOS陽性反応に顕著な変化は認められなかつ た。CD11b陽性反応はコントロール群では、粘 膜下神経叢周囲、絨毛中の神経線維周囲に、鍼刺 激群では、コントロール群に比べ減少し、絨毛先 端部から基部にかけて散在した。

【考察】神経系ではnNOS陽性反応以外すべてに 変化が認められた。TH陽性反応より特にVIPや SPが顕著に増加したことから、交感神経系より も副交感、知覚神経系による腸管への影響が考え られる。また今回の結果は銊刺激による免疫担当 細胞への作用の可能性を示唆する。CD11b陽性 細胞の一つであるマクロファージはNerve Growth Factor (NGF) によって神経を活性さ せることなども知られている。今後、体性感覚刺 激によるCD11b陽性細胞と神経活性との相互作 用について検討する予定である。

キーワード：鍼刺激、腸管、マクロファージ、自 律神経系、知覚神経 


\section{$30-C-13: 24$ \\ 卵巣摘出ラットの血中エストロゲン 濃度に対する鍼刺激の影響}

明治銊尒大学生理学教室

萩原裕子、金本貴行、岡田 薰、川喜田健司

【目的】女性は閉経後にエストロゲンの分泌が減 少し、更年期障害と呼ばれる種々の症状が出現す る。症状には個人差があるが、重症な場合はエス トロゲン補充療法（HRT）が用いられている。 一方、日本女性が希望する治療法の調査では HRTの他、鍼治療も挙げられている。しかし、 鍼治療の更年期障害に対する影響については、ほ とんど明らかになっていない。そこで、卵巣を摘 出した更年期モデルラットを作成し、血中のエス トロゲン濃度に対する鍼刺激の影響を検討した。

【方法】雌性Wistarラット（n=66）を用い12週 齡で必要な手術を行い、18週齡以降を実験に供 した。ラットはそれぞれ無処置群（intact;n=15）、 偽手術群（sham;n=16）、両側卵巣摘出群 (OVX; $\mathrm{n}=17)$ 、両側卵巣摘出後鍼施術群 (OVX + $\mathrm{ACU} ; \mathrm{n}=18 ） に$ 分け、鍼埋め込み刺激から10週間 目に全てのラットから血液を採取し、一部のラッ トからは副腎も採取した。サンプル血液と副腎は エーテルを用いて精製した後、ELISA 法 (enzyme-linked immunosorbentassay) によ り血中及び、副腎のエストラジオール量を測定し た。鍼刺激は、14号鍼に凹凸をつけた後 $1.5 \mathrm{~cm}$ 切断して自家製皮内鍼を作成し、背部正中外方 1 cmで両側性にTh10からL2の部位に埋め込んだ。

【結果】血中のエストラジオール量はintact、 sham と比較してOVXでは減少傾向が認められ、 鍼刺激を与えることにより、intact、shamと同 様のレベルにまで回復した。また、副腎のエスト ラジオール量も鍼刺激により増加傾向を示した。

【考察と結語】以上の結果から、鍼刺激は副腎の エストラジオール分泌機能を六進させ、それによつ て血中のエストラジオール量を増加させる可能性 が示唆された。現在、その基質であるテストステ ロン量についても検討中である。

キーワード：卵巣摘出、エストロゲン、ELISA

\section{$30-C-13: 36$ \\ 痛覚閾値に対する性ホルモンの影響}

明治鍼尒大学生理学教室

岡田 薰、萩原裕子、木村美保、川喜田健司

【目的】銊鎮痛において鎮痛が起こりやすい人と 起こりにくい人がいるが、その詳細については不 明である。近年、鎮痛効果には性差があり、モル ヒネ投与による鎮痛では雄ラットに比べ雌ラット は8倍もの量を必要とすることが報告されており、 痛覚には性ホルモンが関係している可能性が示唆 されている。そこで、雄ラットを去勢し、痛覚閾 值の変化について詳細に検討した。

【方法】Wistar系雄ラットをSham群 $(n=3)$ と 去勢群（n=6）に分け、3ケ月齢で必要な手術を 行った。Tail-flick test（脊髄反射性痛覚テスト)、 Formalin test (上脊髄反射性痛覚テスト)、 Jaw-opening test (三叉神経領域痛覚テスト)、 Colorectal distention (内臓痛覚テスト) の各種 痛覚テストを行った。また、Tail-flicktestにおい ては、 naloxone ( $1 \mathrm{mg} / \mathrm{kg} 、$ i.p.) を投与し、内 因性オピオイドの関与についても調べた。実験終 了時に麻酔下にて採血を行い、ELISA法を用い て血中テストステロン量を測定した。また、精囊 を摘出・湿重量を測定し去勢の影響を確認した。

【結果】いずれの痛覚テストにおいても、去勢の 影響は認められずsham群との差はなかった。 naloxone 投与によって、tail-flick潜時に影響は なかった。血中のテストステロン量および精囊湿 重量は、去勢群はsham群の約 $1 / 10$ 量に減少して いた。

【考察】今回、去勢群で痛覚閾值に変化が認めら れなかったことから、男性ホルモンであるテスト ステロンは痛覚閾值に直接関係していないことが 明らかとなった。また、naloxone投与によって tail-flick 潜時に影響はなかったことから、内因 性鎮痛が持続的に賦活されている可能性はないと 考えられる。痛覚には、女性ホルモンが影響して いる可能性が高いことが示唆された。

キーワード：ラット、痛覚閾値、鎮痛、性ホルモ 


\section{0-C-13: 48 \\ 高血圧自然発症ラット（SHR）の循環 系に及ぼす鍼通電刺激の効果}

筑波技術短期大学鍼众学科生理学

大沢秀雄

筑波技術短期大学鍼众学科

野口栄太郎

志村まゆら
【目的】我々はWistar系麻酔ラットを用いて、 皮膚組織が多い足蹠の鍼通電刺激では血圧上昇反 応を、筋組織が多い足三里穴への同様の刺激では 血圧上昇あるいは降下反応を誘発することを報告 してきた。そこで今回は、高血圧自然発症ラット （SHR）を用いて、足蹠及び足三里穴への鍼通電 刺激による血圧反応を観察し、Wistar系ラット の血圧反応と比較したので報告する。

【方法】実験は雄性SHR4匹（3～4ヶ月齢）、 Wistar 系ラット7匹（3〜4ヶ月齢）を用い、ウ レタン麻酔、人工呼吸下で呼気 $\mathrm{CO}_{2}$ 濃度を一定に 保ち、直腸温を $37 \sim 38^{\circ} \mathrm{C}$ 維持しながら行った。 血圧は大腿動脈から導出し、心拍数は血圧波から 心拍タコメーターによって算出し、それぞれポリ グラフ上に連続記録した。銊通電刺激は後肢足蹠 （第1第2中足骨間）と下腿外側部の足三里穴相当 部位に行った。16号ステンレス鍼を $5 \mathrm{~mm}$ 間隔で 深さ $5 \mathrm{~mm}$ 刺入し、これを刺激電極として、パル 又幅 $0.5 \mathrm{msec} の$ 矩形波で、刺激頻度 $20 \mathrm{~Hz}$ 、刺激 強度を $0.5 \mathrm{~mA} 、 2 \mathrm{~mA} 、 5 \mathrm{~mA} 、 10 \mathrm{~mA}$ 変えてそ れぞれ30秒間刺激した。

【結果と考察】(1)SHRの足蹠の刺激では刺激強 度依存性に血圧上昇反応がみられた。(2)後肢足蹠 刺激による血圧上昇反応は、Wistar系ラットに 比べSHRの変化率の方が高かつた。(3)SHRの足 三里穴の刺激では、ほぼ全例において、5 mA、 $10 \mathrm{~mA}$ 刺激の直後に血圧降下反応がみられた。 さらに $10 \mathrm{~mA}$ 刺激では血圧降下反応に続いて血圧 上昇反応を伴う二相性の反応が高率でみられた。

【結語】麻酔下の高血圧自然発症ラット（SHR） への鍼通電刺激によって、後肢足蹠刺激によって 血圧上昇、足三里刺激によって血圧降下反応が認 められた。

キーワード：麻酔ラット、高血圧自然発症ラット、 鍼通電刺激、血圧
30-C-14:00

\section{炎症動物における鍼鎮痛機序}

一未梢性鎮痛の関わりについて（第2報）-

明治鍼尒大学外科学教室

関戸玲奈、咲田雅一

明治東洋医学院専門学校

石丸圭荘

【目的】既に本学会において、カラゲニン炎症性 痛覚過敏に対する鍼鎮痛が炎症局所へのCRFや IL-1 受容体拮抗薬の投与により拮抗されたこと から、免疫細胞に存在するCRFやIL-1受容体が鍼 鎮痛に関与する可能性を報告した。そこで本研究 では免疫抑制剂のシクロスポリンA (CsA) 投与 による免疫細胞の機能抑制が鍼鎮痛に及ぼす影響 を検討した。また、鍼鎮痛における末梢の $\mu$ オピ オイド受容体の関与を調査するために、 $\mu$ オピオ イド受容体拮抗薬の足底内（ipl）投与が鍼鎮痛 に及ぼす影響を検討した。

【方法】実験はSD系雄性ラット（n=42）を用い、 炎症性痛覚過敏はカラゲニンの左後肢足底への皮 下注入により作成した。痛覚閾値の変化は加圧式 鎮痛効果測定装置（Randall Selitto Test）を用 いて経時的に測定した。鍼通電（EA）は左前脛 骨筋に $3 \mathrm{~Hz}$ で1時間行った。CsAはカラゲニン投 与48時間前と 24 時間前に腹腔内（ip）投与した。 また、 $\mu$ オピオイド受容体拮抗薬にはCTOPを使 用し、EAの1時間前に炎症局所にipl投与した。

【結果】カラゲニンのみを投与したコントロール 群では投与 3 時間後から痛覚過敏を生じ、投与 24 時間後においても痛覚過敏が持続した。それに対 し、EA+Vehicleip投与群、EA+Vehicleipl投与 群では鍼鎮痛は長時間持続した。しかし、 $\mathrm{EA}+$ CsAip 投与群ではEA終了1時間後から、EA+ CTOP $10 \mu$ gipl投与群ではEA終了 3 時間後から 鎮痛効果は有意に抑制された。

【考察】CsA投与により炎症側の鍼鎮痛が消失し た。このことは銊鎮痛に免疫細胞の機能が関与し ていることを示唆している。また、CTOPのipl投 与により鍼鎮痛が消失した結果は、未梢の $\mu$ オピ オイド受容体が鍼鎮痛に関与していると考えられ る。これらのことからEAにより免疫細胞が活性 化され、免疫細胞から放出されたオピオイドペプ チドにより鎮痛効果が引き起こされたと考えられ た。

キーワード : カラゲニン、痛覚過敏、鍼鎮痛、免 疫系、 $\mu$ オピオイド受容体 


\section{0-C-14: 12 \\ ヒト電気鍼の脊髄分節および内因性 鎮痛効果について}

明治東洋医学院専門学校

明治鍼众大学外科学教室

石丸圭荘

咲田雅一

【目的】電気銊鎮痛の作用機序は未梢経穴低頻度 刺激で内因性モルヒネ様物質が賦活され発現する 全身性鎮痛と春髄分節領域を高頻度刺激にて発現 する春髄分節性鎮痛がある。そこで二点識別法を 指標に、両者の鎮痛効果の発現を検討した。

【方法】学生250例（男性147例、女性103例、 平均年齢25.3歳）を対象に、全身性鎮痛を目的に 合谷、足三里に低頻度 $(3 \mathrm{~Hz})$ 鍼通電および腹部 に脊髄分節鎮痛を目的に高頻度 $(100 \mathrm{~Hz})$ 鍼通 電を30分間行った。痛覚閾值の測定は、左右前 腕、下腿、腹部にて二点識別（ノギス）を用いて 鍼通電前、通電後10、20、30分に二点距離の変 化を記録した。

【結果】合谷、足三里に低頻度 $(3 \mathrm{~Hz})$ 鍼通電で は、左右前腕、下腿、腹部にて二点距離は平均 $2.1 \mathrm{~cm}$ に拡大し全身性鎮痛が確認された。また、 腹部に脊髄分節鎮性痛を目的とした高頻度 $(100 \mathrm{~Hz})$ 鍼通電では腹部のみ二点距離が $1.9 \mathrm{~cm}$ に拡大した。

【考察および結語】合谷、足三里への低頻度 $(3 \mathrm{~Hz})$ 鍼通電は内因性鎮痛系を賦活させ全身性 に鎮痛が発現し、腹部高頻度 $(100 \mathrm{~Hz})$ 鍼通電 では刺激を受けた神経分節の知覚遮断効果が発現 したものと思われる。また、両者の鎮痛効果は簡 便に定量でき作用機序を明確に示すことができる ことから教育の現場において活用できると思われ る。

キーワード : 鍼鎮痛、電気鍼、内因性鎮痛、脊髄 分節性鎮痛
$30-C-14: 24$

\section{通電鍼刺激により活性化される内因} 性抗鎮痛機構

和歌山県立医科大学薬理学教室

深澤洋滋、岸岡史郎

【目的】オピオイドの鎮痛作用を減弱させる内因 性物質が存在することから、内因性抗鎮痛機構の 存在が示唆されている。一方、我々はこれまで、 電撃フットショックストレスによる鎮痛作用発現 後に内因性抗鎮痛機構が活性化され、モルヒネ鎮 痛が減弱されることを報告した。そこで今回、通 電鍼刺激（EA）による鎮痛作用発現後の内因性 抗鎮痛機構について検討した。

【対象と方法】実験には SD系雄性ラット （250〜350g）を用いた。ヒト足三里相当部位ま たは非経穴部位に、3Hz、0.1msec durationの 刺激条件で45分間通電し、EAを行った。痛覚間 值の測定は、後肢加圧法に従つた。側脳室内投与 は頭蓋表面に固定したガイドカニューレを介し、 また春髄くも膜下腔内投与は、椎間腔から挿入し たカニューレを介して、術後 1 週間の回復期間の 後に行った。それぞれの投与液量は5 41 1および $20 \mu 1$ とした。

【結果と考察】ヒト足三里相当部位へのEAによ り、抗侵害刺激作用が惹起され、その作用はEA 終了後 15 分以内に消失した。EA後、皮下投与モ ルヒネ $(7 \mathrm{mg} / \mathrm{kg})$ の鎮痛作用は有意に減弱した。 その減弱の程度はEA後からモルヒネ投与までの 時間に逆相関し、EA終了120分後のモルヒネ投 与では減弱効果は認められなかった。一方、非経 穴部位へのEAでは、抗侵害刺激作用およびモル ヒネ鎮痛減弱作用は惹起されなかつた。モルヒネ の側脳室内投与 $(25 \mu \mathrm{g})$ による鎮痛作用はEA の影響を受けなかったが、春髄くも膜下腔内投与 (10 $\mu \mathrm{g})$ による鎮痛作用は有意に減弱した。ま た、EA後のモルヒネ鎮痛減弱作用は、コレシス トキニン (CCK) 受容体拮抗薬（proglumide； $0.02 \mathrm{mg} / \mathrm{kg}$,皮下）の併用処置により阻害された。 以上の結果より、EAにより一過性に活性化され る内因性抗鎮痛機構が脊髄に存在し、その機構に はCCKが関与する可能性が示唆された。

キーワード : ラット、通電鍼刺激、モルヒネ、内 因性抗鎮痛機構、コレシストキニン 


\section{0-C-14:36 \\ 筋ポリモーダル受容器の機械刺激に 対する反応}

東洋医学研究所 ${ }^{\circledR} \cdot$ 愛知地方会

甲田久士、黒野保三

【目的】鍼刺激は経穴部位に機械的な刺激を众治 療は熱刺激及び化学的な刺激を与える。その刺激 の性質から組織に侵害刺激を与えている。その情 報の入力系としての侵害受容器は機械刺激、化学 刺激及び熱刺激に反応するポリモーダル受容器が 関与していると推察される。今までにイヌ精巣ポ リモーダル受容器の機械刺激に対する反応及び炎 症メディエーターを用いた反応について報告した が、今回は筋ポリモーダル受容器の機械刺激に対 する反応について調べたので報告する。

【方法】麻酔下のラットより取り出した長指伸筋一 総腓骨神経標本を用い総腓骨神経より単一の筋ポ リモーダル受容器活動をin vitroで記録しインパ ルス数を計数した。刺激時間は立ち上がり 1 秒、 保持 9 秒の台形波で 10 秒間行った。刺激方法は 1 . 刺激強度依存的、2.2種類 (20g と $60 \mathrm{~g})$ 刺激を連 続的に繰り返し機械刺激に対する反応を調べた。

【結果】1.刺激強度を上げた結果、刺激強度依存 的に反応は増強しなかった。 2.2 種類の連続的に 繰り返した機械刺激では、20gは反応が安定して いた。60gでは反応が減少する傾向がみられた。

【考察】先に報告したイ又精巣ポリモーダル受容 器の機械刺激の反応は、刺激強度依存的に反応が 増強したが、今回筋ポリモーダル受容器に対して は異なる結果を得た。しかし連続刺激では同様な 傾向がみられた。強い刺激では一過性に反応は大 きいが経時的に観察すると反応が減弱することか ら、生体への銊刺激は弱い刺激が適量と推察され る。今回の結果は標本の種差が考えられるが、両 者を詳細に比較検討しなければならない。

【結語】筋ポリモーダル受容器の機械刺激に対す る受容特性を調べることにより、鍼刺激の作用機 序を解明する一助になると考えられる。

キーワード : 筋ポリモーダル受容器、機械刺激、 鍼刺激
30-C-14:48

\section{透熱炎による瞬間的な痛みの記憶と その定量評価}

東海医療学園専門学校

杏林大学保健学部生理学教室

加藤幸子、秋元恵実、小林博子、嶋津秀昭

【目的】我々は痛みの大きさを異種感覚として電 気的な刺激量と比較して定量化する方法を考案し、 その評価を行ってきた。本法では痛み感覚を自分 自身で比較するので、痛みの大きさを記憶できる ならば、過去の痛みについても記憶にある痛み感 覚と刺激量の比較が可能である。この観点から、

クリッピングにより作成した持続的な痛みの記憶 保持が、視覚の短期記憶と同程度の保持率である ことを確認した。しかし、透熱众などの瞬間的な 痛みを対象とした場合、痛みの把握と記憶の保持 は持続的刺激より困難であると考えられる。本研 究では透熱众による瞬間的痛みの記憶について検 討した。

【方法】健康なボランティア（30人）に対して、 左前腕手三里穴周囲3力所に成型器によって成型 された艾を用いて透熱食による刺激を与え、最も 刺激を感じた部位の痛みを本法により測定した。 その後、2分後、4分後、8分後、16分後に施尒時 の記憶に基づいて、同様の計測を行つた。

【結果】本法による測定值の平均は時間の経過に 関わらずほぼ正確に保持されたが、值のばらつき が拡大し、標準偏差は2分後で20\%、16分後で27 \%に広がった。

【考察】瞬間的な刺激による痛みの記憶は、すで に確認している持続的な刺激の記憶と同様に、時 間と共に正確度が減ずることが示された。また、 持続的な痛みに対する記憶が5分経過時に $18 \%$ の ばらつきであるのに対し、瞬間的な記憶はより短 時間でばらつきがやや大きくなる傾向が認められ、 瞬間的な痛みの大きさを記憶することが持続的な 痛みに対する記憶より困難であることが示された。

【結語】瞬間的な痛みに対する記憶は、持続的な 刺激と同様にある程度の保持が可能であるが、そ の保持は難しく、正確に痛みの評価を行うために は刺激後短時間で測定することが必要である。

キーワード：痛み、記憶、定量評価、透熱令 


\section{P-D-09:00 \\ 肩こりに対する鍼治療の臨床効果 について}

- Sham鍼による検討一

明治鍼众大学附属鍼众センター ${ }^{11}$ ・臨床鍼众医学 II 教室 ${ }^{2)}$ ・ 健康鍼众医学教室 ${ }^{3)}$

今井賢治 ${ }^{12}$ 2)、笹岡知子 ${ }^{12}$ 2)、田和宗徳 ${ }^{12)}$ 北小路博司 ${ }^{12}{ }^{21}$ 、矢野 忠 ${ }^{1)} 3$

【目的】肩こりに対する鍼治療の効果を臨床比較 試験から示す前段として、実際の患者における鍼 治療の効果を自作のsham鍼を使用してダブルブ ラインド法から評価したので報告する。

【対象および方法】肩こりを主訴に本学付属鍼尒 センターを受療した患者9名（男性3名、女性5名） を対象とした。患者には本物の鍼と偽鍼のいずれ かを行うことを説明し、書面で同意を得た。評価 には6段階から成る face scale（FS）および visual analogue scale (VAS) を用いた。治療 前の肩こりの程度をFSおよびVASで評価し、そ の後、腹臥位で頚・肩部にsham鍼を行った。刺 激部位は左右の風池、肩井、肩外俞、天宗として、 各部位共にsham鍼で 20 秒間刺激した。sham鍼 終了後、肩こりの程度をFSおよびVASで評価し、 治療前の值と比較した。尚、治療と評価は別の者 が担当し、特に評価者にはどのような治療をおこ なっているのかを伝えずにFSおよびVASを採取 させた。そして当実験を行った後に、本物の鍼治 療を行い、その効果も同一の評価者がFSおよび VASで確認した。

【結果および考察】全例でsham鍼後にはFSおよ びVASの值は減少し、肩こりの軽減する傾向が 認められ、プラセボ効果の存在することが判つた。 しかし、本物の鍼治療後には、より大きくFSお よびVASの值は減少した。また、試験終了後に 偽鍼を行ったのが判ったかどうかを患者に調查し たところ、治療経歴の長い5名の患者は見破って おり、その理由として、刺激時に得気感覚の無かつ た事を上げていた。今回の検討から、肩こりに対 する鍼治療の効果には多少のプラセボ効果の含ま れることが判つたが、鍼治療自体の効果も充分に あるものと思われた。今後、より詳細な臨床比較 試験を適用し検討を続ける。

キーワード：sham鍼、肩こり、visual analogue scale、プラセボ効果
3P-D-09: 14

腰痛に対する鍼通電と経皮的末梢神 経電気刺激のランダム化比較試験

筑波技術短期大学附属診療所

筑波技術短期大学鍼众学科

津嘉山洋、山下 仁 坂井友実

慶友病院整形外科 天貝 均

【目的】腰痛を対象とした鍼臨床試験の現実的な 条件下での介入の適切さを評価するために探索的 な臨床試験を行つた。

【方法】文書による同意の得られた発症より 2 週 間以上経過した下肢痛を伴わない脊椎性の腰痛患 者20名（女性17名、男性3名、平均年齢45歳） を対象とし、無作為に低周波鍼通電（試験群）と 経皮的電気刺激法（対照群）2群に割り付け2週 間（4回）の介入を行った。疼痛緩解スケール (VAS)、日本整形外科学会腰痛治療成績判定基 準 (JOAスコア)、有害事象を評価項目とした。 JOA スコアは自覚所見のうち下肢痛の項目と、 他覚所見の項目を除外して使用した。

【結果】試験期間全体の平均VASは試験群6.5土 $1.6 \mathrm{~cm}$ (平均士標準偏差)、対照群 $8.6 \pm 1.8 \mathrm{~cm}$ と 試験群が良好な結果であった。JOAスコアの総 合点は、初診時には試験群 $16.3 \pm 2.4$ 点、対照群 $15.6 \pm 3.7$ 点であったが、試験終了時には、試験 群18.6点、対照群15.8点と試験群で良好な結果で あった。重篤な有害事象は記録されなかった。

【考察・結語】例数の少ない探索的な試験である が群間の差を検証できる可能性が示された。介入 の設定により異なる結果が得られる可能性があり、 現実に行われている鍼治療と隔たりが少なく再現 性の良い介入方法の設定が、一般化可能性の高い 鍼臨床試験の重要な課題と考えられた。

（謝辞）本研究を助成していただいた東洋療法研 修試験財団および筑波技術短期大学に心より感謝 申し上げます。

キーワード : 鍼、鍼通電、経皮的末梢神経電気刺 激、ランダム化比較試験 


\section{P-D-09:28 \\ 腰痛に対する鍼治療の多施設による ランダム化比較試験}

愛知地方会研究部疼痛疾患班

河瀬美之、石神龍代、堀茂、中村弘典 服部輝男、皆川宗徳、甲田久士、井島晴彦 絹田 章、校條由紀、黒野保三

【目的】腰痛に対する鍼治療の有効性を客観的に 検討する目的で、多施設でのインターネットを用 いた中央管理システムによる無作為化割付法 （JAVA を利用した無作為化割付プログラム）に よるランダム化比較試験を行って医学統計処理を 行つた結果、興味ある結果が得られたので報告す る。

【方法】平成 14 年 8 月より平成 14 年 11 月までの 間に11施設に来院した患者のうち、主訴が腰痛 であった患者64例に対し、中央管理システムに よりA群12例：太極療法+低周波通電、B群13例： 太極療法のみ、C群20例：低周波通電のみ、 D群 19例：偽鍼（鍼管を吒打）の4群にランダムに割 り付けて鍼治療を行い、JOAスコアとVASを使 用して評価した。その後、基本を太極療法十低周 波通電として再度鍼治療を行い再評価した。統計 処理は符号順位検定を用いた。

【結果】JOAスコアの治療前に対する割付治療 後、太極療法＋低周波通電治療後の平均改善率 （\%）はそれぞれA群：22.9、23.3、B群：29.5、 41.4、C群：18.7、36.9、D群：4.0、25.8となり、 D群の割付治療後の改善率のみ有意な差が認めら れなかった。また、各群間に改善に対する有意な 差は認められなかつた。VASの治療前に対する 割付治療後、太極療法十低周波通電治療後の平均 減少率（\%）はそれぞれA群：33.1、35.0、B群 : 30.0、50.2、C群 : 27.2、46.9、D群：4.2、31.9 となり、D群の割付治療後の減少率のみ有意な差 が認められなかつた。また、各群間に改善に対す る有意な差が認められた。

【考察と結語】今回の結果より、偽鍼の有効性は 認められないこと、鍼治療の方法により成績が異 なることが認められた。

キーワード：ランダム化臨床比較試験、腰痛、J OAスコア、VAS、

\section{P-D-10:00 \\ 鼻腔内腫瘍手術後に発症した顔面の しびれに対する鍼治療の 1 症例}

埼玉医科大学東洋医学科

浅香 隆、山口 智、小俣 浩、新井千枝子 阿部洋二郎、廣瀬賢一、大野修嗣、藤岡正志 埼玉医科大学健康管理センター 土肥 豊

【目的】頭痛・顔面痛は,鍼众臨床で取り扱う頻 度の高い症状である。今回我々は、鼻腔内腫瘍手 術後の難治性の顔面部のしびれに対し鍼治療を行 い、良好な成績が得られたので報告する。

【症例】52歳 女性 主婦

主訴）左顔面のしびれ

現病歴）平成11年7月、左鼻腔内腫瘍摘出手術。 同14年1月には顔面部の手術創部形成手術。そ の後、三叉神経第2枝領域にしびれが出現し、 薬物療法行つたが著変なく当科受診。

既往歷) 蓄膿症

現症）身長 $160 \mathrm{~cm}$ 、体重 $52 \mathrm{~kg}$ 、血圧 $154 / 98$ $\mathrm{mmHg}$ 、脈拍98回/分整

左三叉神経第2枝領域のしびれ (+)、手術痕部 の触・痛覚過敏 (+)、瞳孔の大きさ・眼球運 動・顔面筋運動は正常、飲水・洗顔・歯の擦り合 わせにてしびれ（个）

鍼治療方法）顔面手術創部周辺の疼痛閾値の上 昇と循環改善を目的に、左四白・下関にディス ポ鍼 $40 \mathrm{~mm} 16$ 号を用い週2回施術。

【結果】4診目でしびれの範囲が狭くなり、頬骨 部より外側のしびれは消失したが、さらに効果増 強を期待して 6 診目に $1 \mathrm{~Hz}$ で低周波鍼通電療法 (AET) 開始。耳鼻科で上顎洞術後囊胞が指摘さ れていたが、㚘骨部は徐々に改善。症状は安定し 持続効果が延長した為、週1回の間隔に変更。し かし、22診目には睡眠不足と疲労にてしびれが 増悪。AETを $60 \mathrm{~Hz}$ 変更したところ、しびれは 1日間消失し顔面部皮膚温の自・他覚的な上昇。

【考察と結語】本症例のしびれは、手術による神 経の伸展によるものと推測される。長期の鍼治療 により、しびれの領域縮小・程度の軽減を認めた ことは、三叉神経を介する鎮痛効果と、創傷部の 循環改善が考えられる。症状増悪期に周波数を $60 \mathrm{~Hz}$ に変えた結果、より改善が認められた事は、 比較的高頻度の刺激が多くの求心性神経䋊維に影 響を与えるため有効であったと考える。以上より 鍼治療は現代医療において、有効な治療法の少な い顔面のしびれに対し、有用性の高い治療法であ る事が示された。

キーワード : 鍼治療、鼻腔内腫瘍、顔面のしびれ 
3P-D-10: 14

\section{めまいに対する頸・肩部の鍼炎治療 の意義について}

早稲田医療専門学校東洋医療鍼众学科

小岩信義、所 数樹、浅野貴之、坂本真紀 二本松明、鈴木盛夫 町田雅秀

昭和大病院リハビリテーション科

久住 武

関東労災病院耳鼻咽喉科

渡辺尚彦

【目的】めまいに対する鍼尒治療は、主に寛解期 のself-controlを良好に保ち、再発に対する不安 の解消と社会復帰の支援を目的に行うことが重要 と考える。この際、(1) ゙こに、(2)どのような治療 をするかが問題となるが、治療部位・方法の選択 は術者の治療体系によって異なる。今回は、めま い患者の頸・肩部の筋に関する所見から、治療部 位としての頸部・肩部の意義を検討した。

【方法】対象は、関東労災病院耳鼻咽喉科めまい 外来を受診し、平衡機能検査を施行した患者とし た。頸・肩部の筋について、(1)こりの頻度、程度、 部位、めまい発作との関連と（108例）、(2)圧痛 箇所（54例）を検討した（患者群）。この結果を めまいや頸部疾患等の既往がない健康成人（こり; 51例、圧痛;15例）と比較した（健常者群）。

【結果】患者群では、こりの頻度は健常者群と同 程度だったが、こりの程度が高い部位は健常者群 に比べて頸部下部、肩甲上部が多く、肩甲間部は 少ない傾向があった。圧痛でも、頸部下部、肩甲 上部は、頸椎X-P所見（頸椎の前弯減少、勒帯の 石灰化や椎間孔狭小等）との間に関連を認める傾 向があった。末梢性めまいの患者では、片側のこ り、片側の項部・頸部下部・前頸部深層筋部の圧 痛はめまいの病側に多く認めた。

【考察と結語】めまいの随伴症状として頸肩部の 筋のこり・圧痛は、蝸牛症状と共に多く認める。 東洋医学は自覚症状を重視するが、めまいについ ても随伴症状の特徴を捉えて治療に応用していた と推察され、外耳の周囲を巡る経絡は頸部下部、 肩甲上部を循行しているものと考える。頸部下部、 肩甲上部の筋に関する症状は、頸椎の加齢的変化 が一因と考えられ、頸部交感神経の局所的な左右 差と内耳循環の異常にも関わる所見と考える。め まいの鍼尒治療では、頸・肩部の筋・筋膜症状を 指標とした治療部位の選択が、こり等の随伴症状 の改善と頸部交感神経系の調節に重要と考える。

キーワード：めまい、鍼炎治療、頸肩のこり、圧 痛、経絡経穴

\section{$3 P-D-10: 28$ \\ 鍼・温熱・振動の後頭部刺激による 視力回復の即時効果の検討}

日本理工医学研究所

古賀義久

群馬パース学園短期大学

栗田昌裕

【目的】鍼众の視力に対する長期効果はよく知ら れている。今回は視力に及ぼす即時効果を置鍼、 電気温熱、振動の刺激で比較検討した。

【方法】対象は鍼群が成人5名（平均年齢は38土 12 歳)、電気温熱群が成人 5 名（平均年歯怜 $32 \pm$ 15 歳)、振動群が成人 5 名（平均年齢は $29 \pm 8$ 歳） である。刺激時間は 3 分間。銊は 1 寸 6 分 3 番、電 気温熱と振動は振動式電子温熱众（日本理工医学 研究所製）を使用。電気温熱刺激は夕オルで覆い 接触皮膚温度を約 41 度に設定した。振動数は 50 Hzであった。以下の順序で測定した。(1)刺激前 に1回目の視力を測定。(2)3分以上経過した後に2 回目の視力を測定。(3)鍼群では天柱穴に3分間置 銊。電気温熱群、振動群では天柱、風池付近に 3 分間刺激。(4)各群で3回目の視力を測定。

【結果】左右裸眼視力の平均值を示す。平均値の 差はpaired t-testを用いて検定した。鍼群では1 回目 0.29、2回目 0.31、両者の差は0.02で統計的 には上昇は認められなかった。3回目は0.43、1

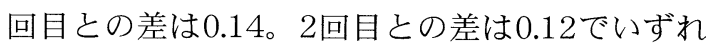
も統計的に有意な上昇だった（ $\mathrm{p}<0.04 、 \mathrm{p}<0.01 ）$ 。 電気温熱群では 1 回目 0.16 。2回目 0.16 。両者の 差は0.00で、統計的には上昇は認められなかった。 3回目 0.21 。1回目との差は0.05、2回目との差は 0.05、でいずれも統計的に有意な差はなかつた。 振動群では1回目 0.41、2回目は0.44、両者の差 は0.03で統計的には上昇は認められなかった。3 回目 0.48。1回目との差は0.07。2回目との差は 0.04 でいずれも統計的に有意な差はなかった。

【考察と結語】視力に対する鍼の即時効果が示さ れた。電気温熱と振動には即時効果が認められな かつた。今後症例を増やして検討したい。

キーワード : 視力回復、即時効果、置鍼、電気温 熱、振動 
3P-D-10:42

顎関節症に対する鍼治療

一症型分類による治療効果の検討一

明治鍼众大学歯科学教室 森西 誠、大藪秀昭 明治鍼尒大学臨床鍼尒医学 II 教室

今井賢治

【目的】顎関節症に対する銊治療は、症型分類に 応じた治療や説明がされていない事が多く、治療 効果は不明確であった。そこで、今回我々は症型 分類（I～IV型）をし、それに応じた治療をする 事で一定の治療成績が得られたので報告する。

【症例】症例 1 は 51 歳女性で、咬合時痛、咀嚼筋 の緊張を有し顎関節症 I 型と診断された。症例 2 は73歳女性で、顎関節痛、関節雑音、咀嚼筋の 緊張を有し顎関節症 III a 型と診断された。症例 3 は33歳女性で、顎関節痛、開口障害を有し顎関 節症 III b型と診断された。症例 4 は60歳女性で、

顎関節痛、開口障害、関節雑音、咀嚼筋の緊張を 有し顎関節症 $I V$ 型と診断された。

治療方法は、顎関節症 I 型には筋緊張緩和目的に 咀嚼筋圧痛部（下関、煩車、太陽穴）に、顎関節 症 III 型には外側翼突筋に、顎関節症IV型には鎮痛 目的に合谷穴の刺鍼を行つた。尚、症例2、4に おいても筋緊張緩和目的の刺銊をあわせて行った。 評価方法には、VAS、開口距離の測定などを用 いた。

【結果】症例1では鍼治療の効果が著明に現れ、

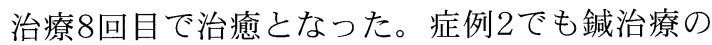
効果は得られ、症状は軽減した。症例3では症状 は殆ど変化せず、銊治療の効果は認められなかっ た。症例 4では疼痛の緩和や開口距離の増加がみ られた。

【考察】I 型では咀嚼筋の緊張を緩和すること、 III a型（復位性円板転位）では円板前方転位の原 因となる外側翼突筋の緊張を緩和すること、IV型 では骨変性により発生する疼痛を緩和することに より、症状の改善を認めたと考えられる。しかし、 III b 型（非復位性円板転位）は、外側翼突筋の刺 鍼だけでは円板の復位ができなかったと考えられ る。症型によって鍼治療も効果が異なり、症型に 応じたアプローチをする必要性が示唆された。

キーワード：顎関節症、症型分類、銊治療

\section{$3 P-D-13: 00$ \\ 女性鍼炎師フォーラムが受けた鍼炎 医療相談について}

女性鍼尒師フォーラム

过内敬子

神奈川地方会

小井土善彦

筑波技術短期大学鍼尒学科

形井秀一

【目的】 21 世紀に入りさまざまな分野で自己決 定と自己責任が求められ始めた。医療においても インフォームドコンセントが不可欠となり正確な 情報を基にどのような治療を選択するかを患者自 らが選ぶ時代になつた。今回お産情報誌やインター ネットを通じて、女性鍼众師フォーラムに寄せら れた 2 年間の相談について報告する。

【方法】これまで女性銊尒師フォーラムに寄せら れた相談件数は 2000 年 10 月から 2002 年 10 月ま でのメール相談 232 件と、2001年7月から 2002 年7月までの電話相談72件の計 304 件であった。 (1)性別、(2)地域、(3)相談者、(4)相談内容、(5)主訴、 (6)対応に津いて検討した。

【結果】(1)性別は女性 $92.4 \%$ 、男性 $7.6 \%$ 、(2)相談 地域は 30 都道府県に及び東京都 $27.9 \%$ 、神奈川 $18.5 \%$ 、千葉 $11.8 \%$ 、埼玉 $9.3 \%$ 、愛知 $6.2 \%$ 、(3)相 談者は本人 $84 \%$ 、家族 $7 \%$ 、団体/企業等 $5 \%$ 、友 人 $4 \%$ 、(4)相談内容は、妊娠中について $82.2 \%$ 、 生活相談等 $7.8 \%$ 、婦人科疾患 $5.6 \%$ 、産後 $3.4 \%$ 、 子ぞもの健康 $1.0 \%$ あった。相談には同一人か ら数回に及ぶものもあった。その他出産場所の選 択、母乳育児等があり他の医療機関や健康関連市 民団体等への紹介を行ったケースもあった。(5)主 訴は逆子124件、安産のため74件、不妊 18 件、 切迫流早産 12 件、腰痛 7 件、つわり 5 件、母乳分 泌不足感 3 件、妊娠中毒症 2 件等であった。逆子 の問い合わせは妊娠32週時36件、34週時28件で あった。(6)相談件数 304件中264件 (86.8\%) は 治療院紹介を希望し、そのうち女性鍼炎師希望は 19\%であった。紹介先は全日本鍼尒学会会員名簿 等を参考にした。希望地域への対応が困難な場合 は電話帳等を参考にするようお願いした。

【考察と結語】妊娠期の相談が多かつた理由とし ては、各種メディアにより情報を得た患者が身近 な鍼尒院に相談できない状況を反映していると考 えられた。今後も鍼尒治療相談に適切に応えるた めには、女性鍼众医学研究の深まりとその普及、 ネットワークの整備拡充が必要であると考えられ た。

キーワード：健康相談、メール相談、電話相談、 産婦人科疾患、ネットワーク 


\section{P-D-13: 14 \\ 高校生における肩こりの実態調査 （第5報）}

京都府立医科大学老化研社会医学 -1 文科学部門
藤田麻里
明治鍼尒大学健康鍼尒医学教室
矢野 忠

【目的】高校生を対象に肩こりについてのアンケー 卜調査を行い、単純集計、学年別・性別について の比較、ストレスの原因や抑うつとの関連性、東 洋医学的所見との関連についての結果を第 1 報〜 4報で報告した。今回は、肩こりの発症に関連す る要因についての検討を行つた。

【方法】京都府下にある 12 府立高校の協力を得 て、6,251名を対象にアンケート調査を行った。 調査期間は 1997 年 10 月 23 日 12 月 2 日であり、 調査は無記名、自記式、集合調査法で行った。第 4報までの結果から肩こりの発症と関連する要因 として考えられる生活習慣、ストレスの原因、東 洋医学的所見などについての項目を選択した。解 析は、性別で分類し、年齢（学年）を考慮したう えで、肩こりなし群をコントロール、肩こりあり 群をケースとして、各要因が肩こりの発症に及ぼ す影響を、単変量のロジスティック解析を用いて オッズ比と95\%信頼区間で算出した。

【結果と考察】肩こりなし群1987名 (34.7\%)、 肩こりあり群3739名（65.3\%）であった。要因 の一例として、東洋医学的所見との検討の一部を 示す。東洋医学的所見のうち、病症ありの多かつ た陽虚 (84.9\%) では男女とも有意差を認め、オッ ズ比（95\%信頼区間）は男性では1.68（1.402.01)、女性では1.86（1.42-2.42）であった。ま た肺の病症（病症ありは60.1\%）でも有意差を認 め、男性では1.91（1.64-2.23）、女性では1.86 (1.57-2.20) であった。その他の全ての病症にお いても有意差が認められた。高校生においては男 女共に東洋医学的な病症を有することが肩こりの 発症に強く関わることが示された。しかも高校生 の肩こりには単一の病症と関わるものではなく、 複数の病症が関与していることが示唆された。

キーワード : 肩こり、高校生、アンケート調査、 要因

\section{$3 P-D-13: 28$ \\ 当研究所における失眠穴応用につい ての調査}

愛媛地方会

愛媛県立中央病院東洋医学研究所

若松貴哉

光藤英彦

【目的】当研究所では、众療を中心的な治療とし て位置付け応用している。奇穴失眠穴についても、 近年、種々の状況で応用している。その実態につ いて、調查検討してみた。

【方法】平成 13 年度初診患者のうち、平成 14 年 11月末日の時点で通院を続けているもの307名を 対象とした。治療者は、のべ11名となっている。 診療録を調査して失眠穴の取穴の有無、取穴の理 由となる愁訴、透熱に要する壮数の変化、治療効 果について検討した。

【結果】失眠穴を治療に応用していたものは、全

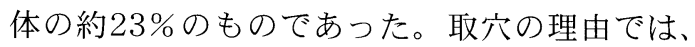
$37 \%$ では膝症状が（膝疾患患者 $37 \%$ で失眠穴が 取穴されていた。）、31\%では浮腫症状が目的で あり、その他は、不眠、足の冷え、皮膚疾患など であった。透熱に要する壮数の変化では、半数の 患者で壮数の減少化が確認できた。

【考察】浮腫を理由に治療を行っている患者では、 浮腫の軽減とともに、透熱に要する壮数の減少が 確認できた。膝疾患患者においては、失眠穴の夕 ならず膝局所の経穴も取穴しており、失眠の効果 についてはさらに調査が必要となつた。

【結語】現在の治療環境では、患者のうち众療可 能なものの割合が減少していくことが予想される。 足底部は多療を積極的に応用可能な部位であるこ とから、今後は注目度が増すと考えられる。足底 部においては穴位反応と原因体質の関係を明らか にすることができれば、いつそう応用の手がかり が増すこととなり、経穴としての重要度も増して いくはずである。

キーワード：失眠穴、尒治療、膝疾患、浮腫 


\section{P-D-13:42 \\ 不定愁訴評価における健康チェック 表と良導絡チャートの検討}

鍼众東洋院・東京地方会 ${ }^{11}$

北海道ハイテクノロジ一専門学校 ${ }^{2}$

時田茂生 ${ }^{1)}$ 、竹之内三志 ${ }^{1)^{2)}}$

【目的】鍼众治療院には、不定愁訴を訴え、ある いは潜在的に不定愁訴を有して来院する患者が多 い。当院では、それらの不定愁訴評価を目的に、 初診患者に対して健康チェック表の記入をお願い し、同時に良導絡の測定を行っている。今回、当 院に来院した初診患者 40 名に対する健康チエッ ク表の集計結果を種々分析するとともに、同時に 測定した良導絡チャートとの関連性を検討したの で報告する。

【方法】対象は、平成14年1月から同年10月まで に当院に来院した初診患者 40 名（男 18 名、女 22 名)、年齢は7〜82才である。健康チェック表は、 全日本銊尒学会研究委員会不定愁訴班により作成 されたものを使用し、重症度別分類、層別分類、 項目別分類などの調查分類を行った。また、同時 に測定した良導絡チャートにおける異常良導絡の 出現傾向を観察し、更に健康チェック表の分析結 果と、異常良導絡の出現傾向との関連性について 検討した。

【結果】重症度別分類では、中等症16名、重症 8 名と中等症以上が 24 名（60\%）であった。また、 層別分類では自律神経失調性項目 $26.5 \%$ 、神経症 性項目 $19.1 \%$ 、うつ状態性項目 $24.8 \%$ 、その他の 項目 $29.6 \%$ であり、項目別分類では、項目No.43 「肩や首筋がこる」の合計点数が 43 点と最も高かつ た。良導絡チャートの異常良導絡の出現傾向に関 しては、重症度別分類において中等症以上に分類 された24名のうち14名（58\%）に、H系の2相 性パターンが出現し、また、層別に特異的な 2 相 性パターンが出現する傾向が観察された。

【考察と結語】健康チエック表の観察から、初診 患者の $60 \%$ が中等症以上に分類され、不定愁訴 を有する患者が多いことが示唆された。また、自 律神経の変調を原因とする不定愁訴の診断に有効 であるとされる良導絡測定との関連性に関しても、 興味ある知見が得られた。

キーワード：不定愁訴、健康チェック表、良導絡 チャート、2相性パターン
3P-D-14:00

\section{明治東洋医科大学（米国）附属鍼診 療所の患者2967名の分析}

明治鍼众大学老年鍼众医学教室

鶴＼cjkstart浩幸

【目的】米国市民の東洋医学への関心が増加して きているが、鍼・生薬治療を受ける患者の年齢層、 主訴、治療回数、治療期間などに関して不明な点 が多い。これらを知ることは米国における東洋医 学診療の実状を知る一助となると考えられる。

【方法】1996年1月から1999年12月の期間にお ける明治東洋医科大学附属鍼診療所の初診患者で、 2000年11月までに最後の治療から6ヶ月以上再 来院がない2967名（男：1031名、女：1936名） の診療録を用い、年齢、性別、主訴、鍼単独治療、 鍼と生薬の併用治療、鍼治療の回数と期間、生薬 処方回数と期間について調査した。なお、上記の 調査は初診時の主訴に対するものとした。

【結果】患者の年齢（mean \pm S.D.） は37.6 13.9 歳（男：38.0 13.3 歳、女 : $37.3 \pm 14.1$ 歳） であった。男女の年齢間には有意差があったが、 男女共に 20 歳以上 40 歳未満の患者が多く、年齢 層の分布は類似傾向を示した。女性が全患者の $65.3 \%$ 、男性は $34.7 \%$ であった。主訴は $74.5 \%$ が症状、 $21.7 \%$ が病名、3.8\%は分類困難な訴え であった。症状は筋骨格系の痛み（33.9\%）・そ の他の痛み $(7.5 \%)$ - 疲労 $(5.2 \%) 、$ 病名はア レルギー性鼻炎 $(2.0 \%)$ ・喘息 $(1.7 \%)$ ・感冒 (1.4\%) の順で多く、分類困難な群では、健康管 理 $(3.5 \%)$ が最も多かつた。鍼・生薬併用治療 は、84.1\%、鍼単独治療は $15.9 \%$ あっった。全患 者の銊治療回数は $4.6 \pm 7.1$ 回（期間は $50.9 \pm 99.9$ 日)、生薬処方回数は $3.9 \pm 5.8$ 回（期間は $51.8 \pm$ 102.0日）であった。同一の主訴における鍼単独 群と併用群の間には、鍼治療回数及び期間に有意 差が認められるものがあった。異なる主訴間にお ける銊治療または生薬処方の回数・期間等にも有 意差が認められるものがあった。

【考察】患者の大多数は、鍼と生薬の併用治療を 希望していることが示唆された。また病名より症 状を訴えて来院する患者が多く、不快な症状をい かに軽減させるかということが重要であると考え られた。主訴の相違によって治療回数や期間が異 なることが示唆された。

キーワード：米国における銊治療、米国における 生薬治療、患者の実態調査 
3P-D-14: 14

\section{埼玉医科大学総合医療センター麻酔 科における鍼治療の実態（第2報）}

埼玉医科大学総合医療センター麻酔科

阿部洋二郎、新井千枝子、宮尾秀樹

埼玉医科大学東洋医学科、健康管理センター

山口 智、小俣 浩、浅香 隆 廣瀬賢一 藤岡正志、土肥 豊

【目的】われわれは、昨年の本学会において当科 鍼外来の実態と鍼治療成績について分析し、ペイ ンクリニック領域における鍼治療の有用性が高い ことを報告した。そこで今回はさらに症例を追加 し、また上位にランクされた顔面神経麻痺患者に ついても詳細に分析し検討した。

【方法】対象は2000年9月から2002年11月まで に当外来で鍼治療を行った患者群から無作為抽出 した143例である。これらの患者群の性別・年齢 別分布、紹介の有無、罹病期間、疾患別 - 症状別 出現頻度、銊治療回数 - 期間、症状別治療成績に ついて分析し、また顔面神経麻痺患者の治療成績 等についても検討した。

【結果】性別では、男性よりも女性の方が多く、 年齢別では50歳代、60歳代、30歳代の順であっ た。紹介により受診した患者は $82.5 \%$ で、当麻酔 科次いで整形外科、耳鼻科の順であった。罹病期 間は 1 ヶ月未満の急性期と 1 年以上のいわゆる慢 性期の患者が多く、疾患別ではBell麻痺 (ベル群)、 RamsayHunt症候群（ラム群）、糖尿病、変形性 腰痛症、高血圧症、帯状疱疹後神経痛が上位にラ ンクされ、症状別では顔面筋麻痺、腰痛、下肢痛、 頸局凝り、上肢痛などが鍼治療の対象となり、鍼 治療成績は著効・有効・やや有効あわせて $62.8 \%$ であった。また顔面神経麻痺患者でベル群とラム 群を比較すると初診時麻痺スコアーはほぼ同様の 值であり、鍼治療による効果率はHouse Brackmann の分類において2段階以上改善した ものがベル群では66.6\%、ラム群では57.1\%と、 ややベル群の方が高值であった。

【考察と結語】当外来では、顔面神経麻痺患者を 取り扱う頻度が高く、鍼治療は難治性の麻痺等に 対しても有効性の高いことが示唆された。また、 退行性病変や悪性腫瘍に起因する諸症状に対して はその原因により有効率が一部異なるものの、ほ ぼ期待すべき効果が得られた。以上より鍼治療は 麻酔科ペインクリニック領域において有用性の高 い治療法と考える。

キーワード : 鍼治療、ペインクリニック、顔面神 経麻痺、実態分析

\section{$3 P-D-14: 28$}

\section{えひめ東医研炎療普及啓蒙活動報告}

愛媛県立中央病院東洋医学研究所

光藤英彦、玉井弘文

【目的】えひめ東医研のIdentityの一翼を担う多 療普及啓蒙活動を報告する。

【方法】尒療普及啓蒙活動を8項目について具体 的に紹介する。(1)初診時众療指導、(2)講演・講座・ 健康まつり、(3)患者用リーフレット・お尒の友、 (4)愛媛新聞社カルチャースクール、(5)病院職員対 象尒療指導、(6)食療モデル地区・西海町众療活動、 (7)愛媛県立医療技術短期大学東洋医学講義、8 ランティア施炎コーナーの設置。

【結果】迷信や旧来の悪しきイメージを取り払い、 主要なツボの効用と取穴のコツ、上手な据え方の コツを習得し、本来の众療の魅力に触れて頂くこ と、また、高齢者の方々には、お众を思い出して 頂き、お众の再発見や新発見に出会って頂くこと が、众療再開のよき機縁となる。すなわち、掘り 起こしや継続施众のアフターケアといった目的の ために施してきた、普及のための数々の工夫と紹 介して、これまでの众療普及啓蒙活動における成 果を確認し、課題を挙げた。

【考察】チリケに象徵されるように、子供の頃か らの众痕が多くの高齢者にみられるが、尒療の習 慣は希薄になりつつある。また、現代は皮膚の弱 い人が増え、火傷を形成する夕イプの众療は、一 般に受け入れにくい時代となっている。従って、 众療普及の要諦としては、お众のじょうずな据え 方のコツを体得し、実際の施炎で心地よさを体感 していただくことに重きを置いて、関心を持って もらう工夫が大切である。

【結語】众療の具体的な利点を、あらゆる機会・ 場所において最大限アピールし、啓蒙に努めるこ とにより、我が国の医療における伝承東洋医術の 有用性に、多くの人々が気づいてボランティア施 炎への参加を実践していただけるよう、一層の普 及啓蒙に努めたい。

キーワード：コルク製コースター、私のカルテ、 お全の手引き、お众の友、ボランティ ア施尒 
$3 P-D-14: 42$

\section{東京都情報サービス産業健康保険組 合東中野保健センターにおける活動 報告}

東京都情報サービス産業健康保険組合東中野保健 センター ${ }^{1)}$ 、パテラ研究所 ${ }^{2)}$ 、筑波技術短期大学 附属診療所 ${ }^{3)}$ 、筑波技術短期大学鍼众学科 ${ }^{4)}$

堀 紀子 ${ }^{1,3)}$ 、松本 毅 ${ }^{1,4)}$ 釜中 明 $^{2)}$ 、森山朝正 ${ }^{4)}$

【目的】東京都情報サービス産業健康保険組合東 中野保健センターは1995年6月に開設され、組合 員およびその家族に対し人間ドックなどの専門検 診、フィットネスなどの場を提供している。今回 我々は専門検診の中の腰痛対策（マッサージ室） として銊治療などを行っているので受診者の実態 を紹介する。

【方法】1995年6月から2002年3月までにマッサー ジ室を受診した初診受診者の性、年代、主訴、他 科受診、鍼治療経験などについて検討した。

【結果】期間内に受診した初診者は1,704名（男 性761名、女性943名)、年代は30代596名、20 代433名、40代298名、50代222名の順で多かっ た。主訴は腰下肢痛1,159名、頚肩背腰部のこり・ 痛み 1,008 名、頭痛・頭重 103 名、眼精疲労 69 名 などであった。他科受診ではなし464名、病院 229 名、接骨院・マッサージなど60名、薬局 54 名、鍼尒院7名などであり、鍼治療経験はなし 897 名、あり446名、不明361名であった。

【考察】我々の施設の受診者はほぼ全員がパソコ ンを使用する事務職であり若い年代層が中心の業 種と考えられ、20〜30代が約60\%を占めていた。 主訴では腰痛対策の専門検診であるため腰下肢痛 が大多数であるが、その他は肩こりなどの運動器 系や長時間のパソコン使用によると思われる眼精 疲労などの訴えが多かつた。他科受診は合併症の 治療を含むため病院が比較的多かつたが、銊治療 経験者数に対して銊尒院受診者は少なかつた。保 険を使えないことや問診上、銊に対する悪いイメー ジを持つ受診者が多かつたことも要因となつてい ると考えられる。

キーワード：企業内鍼治療、活動報告、パソコン
3P-E-09:00

鍼炎院通院患者の施術者の技術評価 に関する疫学的研究

明治東洋医学院専門学校

高野道代、清藤昌平

明治鍼尒大学健康医学教室

福田文彦、石崎直人、矢野 忠

【目的】鍼众院通院患者の満足度は、治療効果、 施術者の技術評価、施術者の信頼度、診療室の清 潔さ、施術者の理解度、施術者の説明度、説明の 分かりやすさ、尋ねやすさが関係していることが 示唆されたことを第50回の本学術大会で報告し た。そこで、今回我々は施術者の技術評価に関連 する要因について疫学的に検討したので報告する。

【方法】対象は、鍼众院通院患者 2210 人とした。 これら対象は、明治鍼众大学同空会会員で開業し ている鍼尒院からランダムに抽出された鍼众院 （101件）に受診した患者であった。調査期間は 平成 12 年 7 月 10 日〜平成 12 年 7 月 23 日の 2 週間と し、調査票は独自で作成したものを使用した。調 査項目は、施術者の技術評価はVisual Analogue Scale (VAS)、その他の項目（QOL、治療効果、 症状、受診状況、環境、治療費、年齢等の基本情 報等）はVAS及び選択式回答法で評価した。調 查は、標本調査による配布郵送調査法にて実施し た。なお、統計解析には、患者の満足度と他の調 查項目との関係は、ピアソンの積率相関係数を使 用し、施術者の技術評価の要因となる項目は重回 帰分析（変数増加法）を使用した。

【結果】回収数は、1319通（59.7\%）であった。 施術者の技術評価（有効回答数: 1239 人）は、平 均81.5 土14.52であった。施術者の技術評価にお いては年齢による有意な差は認められなかった。

施術者の評価と相関が認められたものは、施術 者の信頼度、患者の満足度、治療効果、訴えの理 解度、説明の分かりやすさ、施術者の説明度、尋 ねやすさ、訴えを聴く、丁寧さ、診療室の清潔さ、 妥当な治療費、最高に支払う治療費、治療費の感 想であった。

さらに、重回帰分析では、施術者の信頼度、患 者の満足度、治療効果、妥当な治療費、説明の分 かりやすさが抽出され、施術者の技術評価との重 相関係数及び決定係数は高值を示した。

【考察と結語】本調査の結果、銊众院通院患者の 施術者の技術評価は、高い値を示した。この施術 者の技術評価は、施術者の信頼度、患者の満足度、 治療効果、妥当な治療費、説明の分かりやすさの 要因が深く影響していることが示唆された。

キーワード：良質な医療、鍼尒医療、鍼众院通院 患者、技術評価、調査 


\section{P-E-09:14 \\ 企業内従業員に対する鍼治療・手 技療法の効果}

一職業性ストレスとの関連性の検討一

福岡県立福岡高等盲学校専攻科研修科

沢崎健太、石丸浩徳

【目的】演者らは、平成 11 年より企業内従業員 に対して鍼治療・手技療法を行い、自覚症状及び 職場内健康管理室利用状況、診療報酬点数に及ぼ す効果を報告してきた。今回は、企業内従業員に 対して実施した鍼治療・手技療法と職業性ストレ スとの関連性について検討したので報告する。

【方法】福岡市内のA工場（ビール製造）に所属 する従業員 250 名の内、労働省「作業関連疾患の 予防に関する研究班」ストレス測定研究グループ の職業性ストレス簡易調査を行った 228 名を対象 とした。鍼治療・手技療法は、平成13年5月から 平成 14 年5月の期間に受療を希望した 62 名に実施 し、その効果を検討した。

【結果】職業性ストレス簡易調査の結果、全対象 について、職業性ストレス因子の項目では、コン トロール度、対人関係、仕事の適合性に比して仕 事の負担度のストレス度が高い傾向を示した。受 療回数が 10 回以上の対象群では、その他の対象 に比し、ストレス反応の心理的・身体的ストレス の程度が特に高い傾向を示し、「首肩がこる」、

「目が疲れる」の身体症状に関する質問項目が特 に顕著であった。同時に、他の対象に比し、仕事 への満足度が低い傾向も示した。健康管理室の月 別利用状況については、鍼治療・手技療法実施後 に減少を示した。

【考察】継続的な鍼治療・手技療法を希望した者 は、仕事の負担度が高いと感じ、心理的・身体的 ストレス反応の程度が高いと訴え、仕事への満足 度は低い傾向にあった。このような従業員にさら に継続的に鍼治療・手技療法を行うことは、心理 的・身体的ストレス反応の程度を減少させて仕事 への満足度を高め、労働意欲を向上させるという、 産業衛生上有効な一手段となり得る可能性が示唆 された。また、銊治療・手技療法実施後、健康管 理室の月別利用状況が減少したことから、職場に おける鍼治療・手技療法は医療経済学上有効であ ることが推測されたが、さらに継続的な検討が必 要である。

キーワード：産業衛生、銊、手技療法、職業性ス トレス簡易調査、医療経済

\section{P-E-09: 28 \\ 鍼炎受診患者における健康関連 Q O Lと気分の検討}

東海医療学園専門学校

奥野友香、杉山誠一 財務省印刷局東京病院東洋医学センター

筑波技術短期大学鍼尒学科

安野富美子

坂井友実

【目的】近年、医療行為によってもたらされるア ウトカムの指標として、患者自身の健康感を評価 する健康関連QOLが注目されている。今回、著 者らは鍼众受診患者のQOLを測定し、主訴と気 分の面から検討した。

【対象と方法】平成14年11月7日〜28日に財務 省印刷局東京病院東洋医学センターに来院した鍼 食受診患者のうち調査の同意と協力を得た 42 名 （男性17名、女性25名、56士17歳）を対象とし た。方法は施術者が無記名式の質問紙を患者に配 布し、再来院時に回収した。QOLは（財）PHRC より供与を受けたSF-36を用い、(1)身体機能、(2) 日常役割機能 (身体)、(3)体の痛み、(4)全体的健 康感、(5)活力、(6)社会生活機能、(7)日常役割機能 (精神)、(8)心の健康を得点化し、主訴と気分 (POMS 短縮版) の面から分析した。

【結果】SF-36による鍼众受診患者の QOL は (1) $74.0 \pm 25.4$ 、(2) $57.7 \pm 42.2$ 、(3) $45.3 \pm 17.2$ 、(4) $50.8 \pm 15.8$ 、(5) $63.8 \pm 25.5$ 、(6) $56.8 \pm 25.0$ 、 (7) $69.0 \pm 41.3$ 、861.9 18.1 で国民標準值と比べ (5)活力を除いた全ての項目において低下していた。 そして、運動器系を主訴とする者は(2)日常役割機 能（身体）が低く、頭痛やめまい感を主訴とする 者は(2)と共に(6)社会的機能や(7)日常役割機能（精 神）が低かった。また、気分とQOLとの間に相 関する項目が認められた。

【考察および結語】仕事や日常生活に運動器系疾 患が身体的問題を、頭痛やめまい感が身体的、心 理的問題を与えると患者自身が認識していること から、鍼尒受診患者の健康関連QOLは身体的、 心理的健康があり、QOLの向上には、症状の改 善に加えて心理的な援助も必要であると推測され る。これは、鍼众治療において患者と施術者間に 相互交流の必要性を示唆するものと考える。

キーワード：健康関連、QOL、SF-36、POMS短 縮版、鍼尒 
3P-E-09: 42

\section{鍼炎治療を受療する患者の健康関 連QOL}

$$
\text { -SF-36を用いてー }
$$

筑波大学理療科教員養成施設

森戸麻美、菅原正秋、吉川恵士

【目的】 SF-36は健康関連QOL尺度として、最も 一般的な指標の一つである。鍼炎治療は慢性疾患 を中心に広く利用されており、健康関連QOLの 向上に貢献していると考えられる。今回SF-36を 用いて当施設にて鍼众治療を受療した患者を対象 に、健康関連QOL調査を実施し、以下の 2 点につ いて検討した。

1）鍼众治療を受療する患者における健康関連 QOL 得点と国民標準値の比較。

2）一定期間鍼众治療を受療した患者の健康関連 QOL得点の推移。

【方法】調査対象は平成 14 年 10 月から当施設を 受療した患者である。調査方法は当日の外来にお いてSF-36（日本語版、Vol.2.0）を自己記入させ た。配布方法は、患者が受け付け終了した後、調 查担当者がSF-36を直接配布した。原則として患 者が治療を受ける前にSF-36に記入してもらった。 これは患者と担当鍼众師とのやり取りが調査の回 答に影響することを避けるためである。回収方法 は記入が終了した後、調査担当者に直接手渡して もらった。治療継続の患者においては、4週から 5週目に再びSF-36を自己記入させた。この尺度 は36個の質問項目より構成され、身体機能、身 体の日常役割機能、体の痛み、全体的健康観、活 力、社会機能の制限、精神機能の障害による役割 機能、精神状態の8つのサブスケールに分けて評 価する。各下位尺度得点は素点を $0 \sim 100$ 点の範 囲に換算され、得点が高いほど健康状態が優れて いる。

【結果】当施設を受療した患者のSF-36を各下位 尺度得点に変換し、日本人の国民標準値をもとに、 性別と年齢を調製した偏差得点を算出した。結果 は、全ての下位尺度得点が国民標準值よりも低値 を示した。中でも「体の痛み」は $38.4 \pm 12.6$ と特 に低值を示した。

【考察】このことから鍼多治療を受ける患者の健 康関連QOLは一般国民と比較して低いというこ とが示唆された。

キーワード：SF-36、健康関連QOL、鍼治療

\section{P-E-10:00 \\ 炎刺激がラット腹腔内マクロファー ジに及ぼす影響の検討}

関西鍼众短期大学免疫 - 病理学教室

松尾貴子、笠原由紀、栗林恒一、東家一雄

関西鍼众短期大学解剖学教室

木村通郎

【目的】自然免疫の主要な細胞であるマクロファー ジは、非特異的に細菌や微生物を細胞内に取り込 み、分解処理する。また取り込んだ物質を細胞表 面に提示し、T細胞を介して獲得免疫系を賦活す る。今回、众刺激がこのようなマクロファージの 性質に影響を及ぼすかどうかを調べるため、マク ロファージの領食能とMHCクラス II 分子の発現、 及びサイトカイン産生について検索した。

【対象と方法】対象には雌性Wistarラット（8週 令、 $\mathrm{n}=20$ ）を用い、众刺激群と無刺激群の $2 つ に$ 分けた。众刺激群は背部を除毛し、ネンブタール 麻酔下で脾俞、腎俞相当部位に半米粒大の透熱众 3 壮を週2回、3ヶ月間行った。対照の無刺激群は 同様に背部を除毛し、麻酔のみを行った。众刺激 終了後、生理食塩水で希釈した蛍光ラテックスビー ズ（粒子径 $0.05 \mu \mathrm{m} ）$ を腹腔内に注入し、18時 間後に腹腔内滲出細胞を回収した。それらの細胞 をPE標識抗ラットI-Aモノクローナル抗体で染色 したものと染色してないものに分け、マクロファー ジの細胞内ビーズ取り込みとMHCクラス II の発 現をFCMにて解析した。また残った細胞から RNA を抽出し、RT-PCR法にてIL- $1 \beta$ 、TNF- $\alpha$ 、 iNOSのmRNA発現を検索した。

【結果】サイトカイン遺伝子の発現については、 众刺激群においてIL-1 $\beta$ を除き、TNF- $\alpha$ 、 iNOS のmRNAが減少を示していた。腹腔内滲出細胞 の食食能についても、众刺激群ではビーズを取り 込んだ細胞やクラス II発現している細胞は減少 しており、単核球分画におけるマクロファージの 比率も減少していた。

【考察】IL-1 $\beta$ 、TNF- $\alpha$ 、iNOSはマクロファー ジの活性化の指標である。それらのmRNA発現 の減少はマクロファージの活性化の低下が考えら れるが、FCMではマクロファージの領域が選択 的に減少していたため、それらから得られた mRNA の量に関係すると思われる。今回の実験 から众刺激はマクロファージの遊走能に影響を及 ぼした可能性が示唆されるが、残念ながら遊走能、 食食能とも尒刺激群では増強は見られなかった。

キーワード：マクロファージ、食食能、iNOS 


\section{P-E-10: 14}

\section{3,5-ジカフェオイルキナ酸がラット 脾細胞サイトカイン産生能に及ぼす 影響}

関西鍼众短期大学解剖学教室

東家一雄、五十嵐純、木村通郎

関西鍼众短期大学東洋医学基礎教室

大西基代、戸田静男

関西鍼众短期大学免疫病理学教室

松尾貴子、笠原由紀、栗林恒一

【目的】艾含有成分は施炎で熱変性を受けた皮膚 組織内へ浸透し、皮内で種々の生物活性を示すこ とが推察されている。今回、それら含有成分のひ とつである3,5-ジカフェオイルキナ酸（DCQA） が免疫細胞へ及ぼす影響についてサイトカイン遺 伝子の発現様式を指標に検索を行った。

【対象と方法】対象には成獣Wistar系ラット （10 週齢、雌性、12匹）を用いた。それら動物 の脾蔵から得た細胞浮遊液を6ウェル培養プレー トに巻き込み、高速液体クロマトグラフィーにて ヨモギ抽出液から分取した 3,5-DCQA水溶液を 10-4 M、10-5M、10-6M濃度で添加して培養し、 脾細胞を刺激した。培養開始後 $24 、 48$ 時間で各 ウェルより細胞を回収し型の如く totalRNAを抽 出、逆転写酵素でcDNAを合成した後にラットイ ンターフェロン- $\gamma$ （IFN- $\gamma ）$ に対するプライマー を用いて reverse transcription-polymerase chain reaction (RT-PCR) を行った。得られた PCR増幅産物はアガロースゲル電気泳動にて展 開し、IFN- $r$ のRNA発現様式を解析した。

【結果】3,5-DCQA刺激脾細胞におけるIFN- $r$ の mRNA発現は培養時間の経過に伴い増加する傾 向が見られ、中でも10-5M3,5-DCQAを添加した 48時間培養群では、対照群に比べて有意に高い 発現量が認められた。10-6 M添加群でも10-5M 添加群にほぼ匹敵する発現増加が示されたが、 10-4 M添加群ではその程度は低かった。

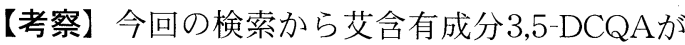
免疫細胞へ直接的に作用し、免疫賦活作用を持つ サイトカインIFN- $\gamma$ の産生をmRNA発現レベル で促進することが示された。このことは艾含有成 分のもつ生物活性が众の免疫系への作用に関与す る可能性を示唆している。

キーワード：ラット、脾細胞、3,5-ジカフェオイ ルキナ酸、IFN- $\gamma$ 、RT-PCR

\section{$3 P-E-10: 28$ \\ 鍼通電刺激がGABA・グリシンを介し て脊髄後角での痛覚抑制作用を賦活 化する可能性についての電気生理学 的検討}

関西鍼尒短期大学生理学教室

武田大輔、内田靖之、樫葉 均 錦織綾彦、上田至宏

【目的】疼痛緩和の目的に鍼通電刺激が臨床上の 一手段として良く用いられている。しかし、鍼通 電刺激が末梢もしくは中枢のどこで作用している かは今のところ明らかではない。そこで今回、我々 はこの作用が中枢神経を介しているものではない かと見込み、春髄後角深層で中枢神経の主な抑制 性伝達物質であるGABA・グリシンのレセプター のチャネルレベルでの応答を電気生理学的に検討 した。

【方法】イソフルレン麻酔下に4週-6週令の成熟 $\mathrm{SD}$ 系ラット5匹から春髄を摘出し、マイクロスラ イサーを用い左右どちらか一方のL5神経根を付 した $0.6 \mathrm{~mm}$ の脊髄スライス標本を作成した。記 録は人工脳脊髄液還流下にブラインドパッチクラ ンプ法を用いて興奮性伝達物質であるグルタメー トレセプターのブロッカー下で脊髄後角深層より 行った。刺激は神経根を吸引電極で保持しながら 頻度 $20 \mathrm{~Hz} 、 \mathrm{C}$ 線維間值以上の電流で 3 分間刺激し た。また記録はC-fiberの刺激に対する感度をあ げる目的でC線維に多く発現するVR1レセプター のアゴニストであるカプサイシンを神経活動が賦 活化されうる閾值以下の濃度（10nモル）の連続 投与下で行った。

【結果と考察】 $20 \mathrm{~Hz} 、 \mathrm{C}$ 線維閾値以上の刺激で 脊髄後角深層でのGABA、グリシンによる抑制 性応答の増大が観られた。これらの作用は中枢の 主な興奮性伝達物質グルタメートを介するもので はなく未梢神経刺激による中枢での未知の伝達物 質放出によるGABA、グリシン含有神経細胞へ の作用である可能性が示唆された。末梢での鍼通 電刺激は脊䯣レベルではC線維を介して抑制性伝 達物質の遊離を増大する事により鎮痛効果を示す 可能性が示唆された。今後、刺激閾值、頻度、間 隔などを変えての検討が必要であると考えられた。

【結語】鍼通電刺激は未梢神経を介して中枢に作 用し鎮痛を起こす事が示唆されたので、痛夕に対 する臨床応用上有用であると考えられた。

キーワード : パッチクランプ、脊髄スライス、鍼 通電刺激 
3P-E-10:42

\section{鍼遺伝子AIG1の完全長決定の試み}

後藤学園ライフエンス総研情報科学研究部 ${ }^{11}$ 岩手医科大学歯学部口腔生化学講座 ${ }^{21}$

尾西恭亮 ${ }^{1)}$ 、高松邦彦 ${ }^{11}$ 大田美香 ${ }^{1)}$ 、高岡 裕 $^{1,2)}$

【目的】我々は鍼の治効メカニズムを分子レベル で解明すべく、遺伝子発現を指標に生命情報科学 の手法で解析をおこなっている。これまでに、鍼 通電刺激が遺伝子発現変動を誘発すること、鍼刺 激で発見した新規遺伝子AIG1 (Acupuncture induced gene 1)のクローニングなぼについて 報告してきた。最近、完全長cDNAの決定が可能 なオリゴキャップCDNAライブラリ一実用化と、 マウスゲノム解析の成果の情報公開により、生命 情報科学を用いた詳細な解析が可能になった。そ こで、我々が決定したcDNAが完全長かどうか検 討を加えたので報告する。

【方法】AIG1遺伝子の解析は、（1）オリゴキャッ プCDNAからのAIG1遺伝子増幅、マウスゲノム デー夕利用による（2）PCR法と（3）新規遺伝子 発見プログラム解析、の 3 種類の方法でおこなつ た。なお新規遺伝子発見プログラムによる解析に は、転写/翻訳産物による遺伝子発見プログラム GENEWISE2 (http:// www . sanger.ac.uk / Software / Wise2/) や、ゲノム比較による遺伝 子発見プログラム ROSETTA (http:// www. theory.1cs.mit.edu/crossspecies) に加えて、 FGENESH (http :// genomic . sanger.ac . uk / gf / gf . shtml) や GENSCAN (http:// CCR 081. mit.edu/GENSCAN.html) 等の等の ab init ○プログラムも用いた。

【結果・考察】我々が決定したcDNA配列はほぼ 完全長に近いことが明らかになった。今後更に詳 細な検討を加えた後、米国NIHのゲノムデータベー スのGenBankに登録しているAIG1遺伝子の配列 情報を更新する予定である。また、従来の実験的 手法に加えて、計算機利用の生物学的な解析手法 の有効性も確認できた。

キーワード：AIG1遺伝子、完全長cDNA、 $a b$ initio 遺伝発見プログラム

\section{$3 P-E-13: 00$ \\ 風池への鍼刺激による脳血流の変化}

東京大学医学部生体防御機能学講座秋山聡子 東京大学医学部アレルギー・リウマチ内科

磯部秀之

【目的】我々は、鍼刺激の中枢神経系への作用を 検討してきているが、今回は、風池への鍼刺激が 脳血流に及ぼす影響について観察した。

【方法】健常成人を対象に、両側の風池に鍼刺激 （雀豚1分、置鍼5分）を行い、脳血流の変化を観 察した。方法は、網膜中心動脈・椎骨動脈・脳底 動脈について、汎用超音波画像診断装置 LOGIQ 500 用い、刺激前から刺激後60分までの血流速 度と血管抵抗を測定した。同時に、血圧モニタに より上肢の血圧と脈拍数の測定も行った。また、 問診表から自覚症状等についての検討を行い、測 定結果との関連性を考察した。

【結果】網膜中心動脈及び脳底動脈は、風池への 鍼刺激により、血流速度の増大と血管抵抗の減少 が認められた。特に、眼の違和感・眩暈など、選 穴の目標となるような自覚症状が問診表に見られ たものでは、血流増加の傾向が顕著であった。上 肢の血圧や脈拍数については、特徵的な変化は見 られなかった。

【考察】風池は、眼疾患の治療に使用頻度の高い 経穴の一つであり、脳血管障害にも多く使用され ている。一方、網膜中心動脈は眼底部、脳底動脈 は脳幹部を栄養する重要な血管である。今回の結 果から、風池への鍼刺激は、それらの血管の血行 動態を改善したと考えられるが、このことは、風 池という経穴の適応や有効性を示唆するものとし て興味深い。また、脳血流変化と上肢の血圧や脈 拍数に関連性が見られなかつたことからは、風池 への鍼刺激が、全身の循環動態とは異なる機序で 脳循環に影響を与えている可能性が推察される。

【結語】健常成人において、風池への鍼刺激によ り、網膜中心動脈及び脳底動脈の血流増加が認め られた。

キーワード：風池、脳循環、鍼刺激、超音波画像 診断装置 


\section{$3 \mathrm{P}-\mathrm{E}-13: 14$ \\ 合谷鍼刺激：正常人脳波の確立密度 関数、線形・非線形解析}

千葉地方会

木南真紀子、金井正博、酒井茂一、元吉正幸 森田和利、小林詔司、石原克巳、松下嘉一 千葉大学大学院医学研究院神経情報統合生理学

下山一郎

【目的】鍼众治療は効果あるが、そのメカニズム は解明されていない。鍼刺激で脳波 $\alpha$ 波増加によ りリラックス度増加が報告されているが、逆の症 例の存在など、中枢神経系への影響は不明な点が 多い。鍼刺激の中枢神経系におよぼす短期効果を しらべる目的で、健康人に合谷 1 分間置鍼の影響 を、脳波で確率過程解析・線形解析・非線形解析 にて、被験者の背景を考慮に入れて検討した。

【方法】被験者はボランティア9名（22～30歳）： 鍼未経験者4名、鍼経験者5名、験者1名（50歳）

刺激部位:左合谷 刺激は安静閉眼座位にて1) 安静 $1 \mathrm{~min}(\mathrm{P} 0) 、 2 ）$ 浅部合谷置鍼 $1 \mathrm{~min}(\mathrm{P} 1)$ 、 $3 ）$ 深部合谷置鍼 $1 \mathrm{~min}(\mathrm{P} 2)$ 、脳波記録:両耳架結 合基準にて、国際10/20法19部位から current source derivation で導出し左右半球の各 3 部位 (前頭:F3/4、中心: $\mathrm{C} 3 / 4$ 、頭頂部:P3/4) について 以下の演算を施行した。解析は、1) 確率密度関 数の尖度と歪度、2）パワースペクトルは対照を 分母にlog10にて基準化パワー、3）コヒーレン ス、4）バイスペクトル、5）バイコヒーレンス の5項目検討した。【結果】1）確率密度関数の 尖度は刺激間で有意、記録部位間でも有意であっ た。P0の尖度が最も大きく、P1の尖度が小さかつ た。部位ではP3,C3,P4,F3,C4,F4の順であった。 歪度は有意でなかつた。2）パワースペクトルで は、未経験者 4 名中 3 名が $\alpha$ 波帯において減少で あった。経験者5名では全例に $\alpha$ 波帯に増加と減 少が混在し、かつ $\beta$ 波帯に増加が見られた。3)

コヒーレンス・バイスペクトル・バイコヒーレン スには一定の傾向が見られなかつた。

【考察】確率密度関数は刺激間に有意な差がめら れP1-P2に脳波で差が認められた。パワーの結果 からは、未経験者 4 名ともに $\alpha$ 遮断が観察された。 これに対して、5経験者からは $\alpha$ 波帯増加が観察 されるが $1 \mathrm{~Hz}$ 解像度で詳細に見ると、減少も見ら れた (4/5例)。今回はコヒーレンス、バイスペ クトル、バイコヒーレンスでは分類できなかつた が、これらを総合すると脸内信号処理がさらに詳 細に推測され、個人差による銊刺激の脳内信号処 理の違いと推測した。銊の中枢神経作用の個人差 の解析は、今後の課題である。【結語】銊経験の 有無が脳波変化に関与することが推測され、被験 者の背景を考慮に入れて検討することが重要だろ う。症例を増やしさらに詳細な検討を要す。

キーワード : 合谷、脳波、確率密度関数、線形・ 非線形解析

\section{$3 \mathrm{P}-\mathrm{E}-13: 28$ \\ 鍼による脳循環の変化（第2報）}

一合谷への鍼と触圧刺激の比較一

富山県国際伝統医学センター

田口裕紀子、上馬場和夫

横浜市立大学医学部解剖学第 2

久島達也

【目的】合谷への銊亡触圧刺激の脳循環への影響 を調査・比較した。

【方法】健常成人 9 名（平均年齢：35 3 7歳）を 対象に、同意の後、第 1 報の結果から脳循環の非 特異的変動がない閉眼後1分目以降の結果を解析 した。安静座位で閉眼開始後 2 分目から1分間、 鍼刺激あるいは触圧刺激を行う。鍼刺激は、寸 3-2 で同一鍼尒師が旋捻し、触圧刺激は、Digital forcegauge を使い、 $1.5 \mathrm{~kg} / \mathrm{cm}^{2}$ の圧を 4 秒間隔で 与えた。鍼と触圧刺激は、無作為の順序で行つた。 呼吸制御はなし。室温 $24 \pm 1{ }^{\circ} \mathrm{C}$ 。測定項目は、 $\mathrm{T}$ CDにより中大脳動脈のPulsatility index (PI:血 管抵抗の指標）を測定、Near Infrared Spectroscopy により、前頭葉表面の組織Hb濃度 変化（前額部にセンサー装着）、僧帽筋部 $\mathrm{Hb}$ 濃度 変化（僧帽筋部）を測定。さらに、連続血圧 • ECG 測定装置により、一拍毎の血圧とRR変動を 測定した。

【結果と考察】合谷への鍼刺激では、心拍数の減 少と前頭葉表面血液量の減少の傾向を認めた。前 頭葉表面と僧帽筋部の血液量の変化は相反する傾 向がみられた。また、触圧刺激による前頭葉表面 血液量とPI值とは、鍼刺激の場合と相反する傾向 を認めた。全身血圧の有意な変化は認めなかつた。

【結語】合谷への鍼刺激では、前頭葉表面の循環 抑制を示唆する結果が得られた。健常人での脳循 環の部分的な変化であろうが、触圧刺激と相反す る例があり、両者の作用機序の違いが示唆された。

キーワード : 脳循環、鍼刺激、触圧刺激、 $\mathrm{TCD}$ 、 組織 $H b$ 濃度 
$3 \mathrm{P}-\mathrm{E}-13: 42$

\section{自律神経と血圧の左右同時測定 （第13報）}

一腕の血圧と比例しない脳の血流一

新潟地方会

中村吉伸

【目的】これまで症状に伴う血圧変化は健康管理 の一つの目安とされてきて、腕の血圧は脳の血圧 と比例するものとして扱われてきたが、左右の血 圧と左右の内頸動脈の流量変化を測定してみると、 多くの場合は全く別個の変化を示すことが分かつ たので症例をもって報告する。

[方法］脳血管に問題がある場合の症例 1 と、高 血圧症とされている症例 2 につて、左右の内頚 動脈の血流変化を外耳道に於いて皮膚温度を測定 し、血圧は上腕部で測定しバランス変化を比較検 討した。（使用機器：テルモ耳式体温計M20一対、 OMURONデジタル自動血圧計一対で構成される 機器)

【結果】症例 1 、脳底動脈硬化症と右肩の自発痛 を訴える74才男性の治療の前後

治療前：右耳35.6度左耳34.8度 右腕 $128 / 85 \mathrm{mmHg}$ 左腕 $136 / 84 \mathrm{mmHg}$

治療後：右耳35.2度左耳35.2度 右腕 $106 / 70 \mathrm{mmHg}$ 左腕 $109 / 72 \mathrm{mmHg}$

症例2、腰と右膝の運動時痛、右膝の伸展制限 を訴える60才女性

治療前：右耳 35.8 度 左耳35.5度 右腕 $165 / 93 \mathrm{mmHg}$ 左腕 $161 / 99 \mathrm{mmHg}$

治療後：右耳 35.8 度 左耳 35.8 度 右腕 $133 / 84 \mathrm{mmHg}$ 左腕 $128 / 83 \mathrm{mmHg}$

症例 1 では右肩の痛みの消失後、左右の耳の温 度は高かった側では下がり低かった側では高くなっ て左右が等しくなった。症例 2 では明らかな血圧 変化と症状消失が有ったのに、耳での温度変化は ほとんど認められなかつた。

【考察及び結語】結果より、知覚神経への刺激で 片側の脳が活動しているときは、左右の脳の血流 バランスに影響がでる場合もあるので、症状の強 さを知るのには脳への血流量変化が重要な指標と なるものと考えられる。また腕での血圧が大きく 変わっても、単位時間内に脳へ流込む血液量は安 定しているという周知の事実を再確認できた。腕 の血圧は個々の腕の血管の緊張に左右されるので、 現行の血圧測定方法や基準に基づく血圧の評価に は再考が必要と考えられる。
$3 P-E-14: 00$

連続施炎刺激がハンドリングストレ ス負荷ラット前頭前野皮質の細胞外 ドーパミンおよびセロトニン動態に 及ぼす影響

明治鍼尒大学基礎鍼尒医学教室

新原寿志、尾崎昭弘

明治鍼众大学健康鍼众医学教室

竹田太郎、福田文彦、矢野 忠 明治鍼众大学臨床鍼众医学 II 教室北小路博司 明治銊尒大学薬理学教室 栗山欣彌

【目的】食刺激の抗ストレス作用を明らかにする ために、ハンドリングストレス負荷によるラット 前頭前野皮質の細胞外ドーパミン量およびセロト ニン量の経時的変化に及ぼす連続施众刺激の影響 について検討した。

【方法】対象は Wister系ラット雄 $\quad(n=6$ 、 230-250g）とし、剃毛後、2mgのモグサを背部 中央に毎日10壮、連続14日間にわたり施尒した。 細胞外ドーパミン量およびセロトニン量の測定に はマイクロダイアリシス法を用い、透析液はPFC (AP:3.2、L:0.8、D:5.3) に埋め込まれた透析プ ローブ（AI-8-3、エイコム社）から連続回収し、

リアルタイムでオートインジェクタに送られ、6 分毎にクロマトグラフィ装置（HTEC-500、エ イコム社）により分析された。ハンドリングスト レスは、合皮製の手袋をはめた掌でラットの背部 全体を軽くタッチすることにより18分間行った。

【結果】ハンドリングストレス負荷により、対照 群 $(\mathrm{n}=3)$ のPFCの細胞外ドーパミン量は、刺激 開始後 18 分で最大 $232 \pm 22 \%$ (Mean $\pm \mathrm{SE}$ ) と刺 激前値に比較して著明な増加が観察された。セロ トニンも同様に、刺激開始後 30 分で最大 $139 \pm$ $19 \%$ と著明に増加した。一方、連続施众群 $(\mathrm{n}=3)$ の細胞外ドーパミン量は、対照群に比較 してハンドリングストレスによる増加量は、刺激 開始後30分で最大 $167 \pm 12 \%$ と低く、その増加開 始時間も遅れる傾向が示された。セロトニン量で も、増加開始が遅れる傾向が観察されたが、刺激 開始後 24 分で最大 $166 \pm 27 \%$ と、増加量の程度 に差は認められなかった。

【考察とまとめ】連続施尒刺激により、ハンドリ ングストレス負荷に対するPFCの反応は抑制され る傾向が見られたことから、众刺激による抗スト レス作用の一端を示すことができた。今後、これ ら反応の抑制のメカニズムおよびその生理学的意 義について検討を進める必要があると考えられた。

キーワード：連続施众刺激、ハンドリングストレ ス、マイクロダイアリシス法、ドー パミン、セロトニン 


\section{P-E-14: 14}

\section{拘束ストレスに対する鍼通電刺激 の影響（第4報）}

一下肢刺激によるセロトニン量の変化一

国立身体障害者リハビリテーションセンター理療 教育部

京都府立医科大学法医学教室

加藤 麦

明治鍼众大学健康鍼众医学教室

吉本寛司

矢野 忠

【目的】前回の本学会にて我々は下肢への鍼通電 刺激（EA）が拘束ストレスにより変動した脳内 ドパミン（DA）量を補完し、刺激頻度の違いに より異なる反応を引き起こすことを明らかにした。 今回脳報償系DA系と共役する脳内セロトニン (5-HT) 系に対する拘束ストレス状態下での下肢 EAの作用について検討した。

【方法】雄性SD系ラットを無刺激コントロール 群、拘束ストレス群、拘束十低頻度EA群、拘束 十高頻度EA群に分けた。拘束ストレスは拘束帯 を用いて 10 分間固定し、EAはストレス負荷状態 で足三里穴相当部位へ低頻度では $1 \mathrm{~Hz}$ 、高頻度で は $100 \mathrm{~Hz} 、 10$ 分間行った。脳報償系の側坐核 $(\mathrm{ACC})$ 、線条体 $(\mathrm{C} / \mathrm{P})$ 、前頭前野皮質 $(\mathrm{FC})$ 、 中脳黒質 - 腹側被蓋野 $(\mathrm{S} / \mathrm{N})$ 、背側縫線核 （DRN）の5-HTと代謝産物5-HIAA量を高速液体 クロマトグラフィーにて定量した。

【結果】拘束ストレス群の5-HT量は無刺激コン トロール群に比べてFC、ACC、C/Pで減少し、 DRNで増加した。 $[5-\mathrm{HIAA}] /[5-\mathrm{HT}]$ 比はFCと ACC で増加した。低頻度EA群の5-HT量は拘束 ストレス群に比べFC、ACC、C/Pで増加し、 DRN では減少した。[5-HIAA]/[5-HT]比はFCと C/Pで減少した。高頻度EA群の5-HT量はACCと $\mathrm{C} / \mathrm{P}$ で拘束ストレス群に比べ増加し、[5-HIAA]/ [5-HT]比はFCとC/Pで減少した。

【考察】低頻度EAは、拘束ストレスにより変動 した5-HT量をいずれの部位でも補完する作用が みられたが、高頻度EAではFCとDRNにおける 補完作用がみられなかった。5-HT系におけるこ れらの相違が、前回報告したDA系に対するEA の異なる反応を引き起こす可能性が考えられる。

【結語】 EAは拘束ストレスによる5-HT系の変動 を補完し、DA系に働きかけている可能性が示唆 された。

キーワード : 拘束ストレス、鍼通電刺激、セロト ニン、脳報償系

\section{$3 \mathrm{P}-\mathrm{E}-14: 28$}

慢性炎刺激の脳内モノアミンに及 ぼす影響

\author{
一刺激部位による比較一
}

明治鍼尒大学健康鍼众医学教室

福田文彦、矢野 忠

国立身体障害者リハビリテーションセンター

加藤 麦

京都府立医科大学法医学教室

吉本寛司、安原正博

明治鍼尒大学薬理学教室

栗山欣彌

【はじめに】我々は、既に鍼通電刺激がストレス による脳内モノアミン変化を補完する作用を本学 会で報告した。今回は、慢性食刺激の刺激部位の 違いによる脳内ドパミン (DA)、セロトニン (5HT)、それらの代謝産物（DOPAC、5HIAA） 量変化を指標に検討した。

【方法】雄性SD系ラットを用い、食刺激群とコ ントロール群に分けた。众刺激群は、頭頂部（天 門穴相当部位 $: n=5$ )、体幹部（腎俞穴相当部位： $n=5$ )、下肢部（足三里穴相当部位 $: n=5$ ）に分け た。1回5壮の施尒（重さ $1 \mathrm{mg} 、$ 円錐状の艾）を 10日間行った。コントロール群は、食刺激と同 部位に同じ艾を置き線香にて点火したのちすぐに 取り除いた $(n=3 \times 3)$ 。10日目の施众終了後 1 時 間以内に断頭した。速やかに脳を摘出し、側坐核、 線条体、前頭前野皮質、扁桃体、外側視床下部、 背側縫線核、中脳黒質 - 腹側皮蓋野、海馬の8領 域に分画した。脳内モノアミン含有量は、電気化 学検出器接続高速液体クロマトグラフィーで定量 した。

【結果】体幹部尒刺激群では、側坐核DAが増加 する傾向を示し、線条体DOPAC / DA比が有意 に増加した。下肢部众刺激群では、前頭前野皮質 $\mathrm{DOPAC} / \mathrm{DA}$ 比が増加する傾向を示した。頭頂 部众刺激群においては、有意な差は認められなかっ た。

【考察・結語】慢性食刺激では、刺激部位による 脳内モノアミン量が変化する傾向を示した。慢性 体幹部食刺激は、中脳辺縁系DA系、黒質線条体 系DA系、慢性下肢部尒刺激は、中脳皮質系DA 系に対して作用することが認められた。これらの 部位は、脳報償系に関与する部位である。慢性尒 刺激は脳報償系DA神経系に作用し、行動の動機 付け、情動変化に影響を与えることが示唆された。

キーワード：慢性众刺激、ドパミン、セロトニン、 脳報償系、脳内モノアミン 